\title{
Republic of Mozambique: Selected Issues and Statistical Appendix
}

This Selected Issues and Statistical Appendix on Republic of Mozambique was prepared by a staff team of the International Monetary Fund as background documentation for the periodic consultation with the member country. It is based on the information available at the time it was completed on December 13,2000. The views expressed in this document are those of the staff team and do not necessary reflect the views of the government of Republic of Mozambique or the Executive Board of the IMF.

The policy of publication of staff reports and other documents by the IMF allows for the deletion of market-sensitive information.

To assist the IMF in evaluating the publication policy, reader comments are invited and may be sent by e-mail to Publicationpolicy@imf.org.

Copies of this report are available to the public from International Monetary Fund - Publication Services 70019 th Street, N.W. - Washington, D.C. 20431

Telephone: (202) 6237430 - Telefax: (202) 6237201

E-mail: publications@imf.org • Internet: http://uww.imf.org

Price: $\$ 15.00$ a copy

\section{International Monetary Fund Washington, D.C.}




\section{INTERNATIONAL MONETARY FUND \\ REPUBLIC OF MOZAMBIQUE \\ Selected Issues and Statistical Appendix}

Prepared by a staff team comprising Jürgen Reitmaier (head-AFR), Stefania Fabrizio (AFR), Alison Scott (AFR), Alessandro Rebucci (PDR), Alvaro Manoel (FAD), and Arnim Schwidrowski (Resident Representative)

Approved by the African Department

December 13, 2000

Basic Data .

I. Selected Public Finance Issues ....................................................................... 7

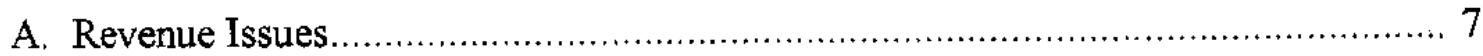

B. The Expenditure Process .......................................................................... 10

II. Why Did Mozambique Fall Into Debt? Mozambique's Debt Burden in

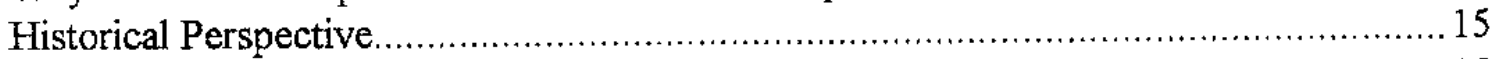

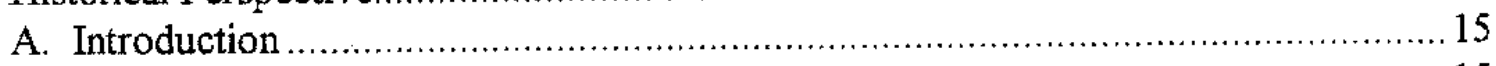

B. Mozambique's External Debt Burden ............................................................ 15

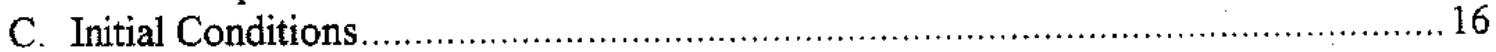

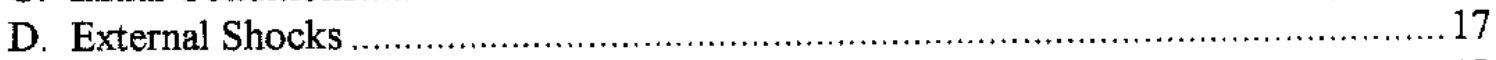

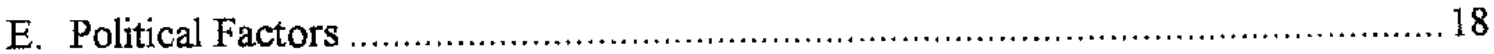

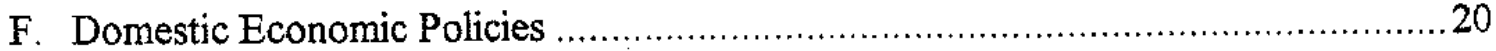

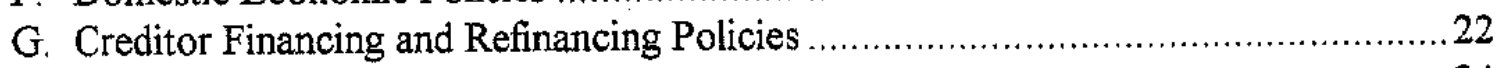

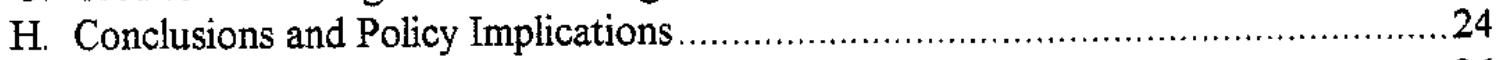

Annex: Debt Relief Under Traditional Rescheduling Mechanisms ................................ 36

III. Equilibrium Exchange Rate and Its Determinants ............................................... 41
A. Introduction
B. Background
C. Theoretical Framework and Empirical Model ..............................................42

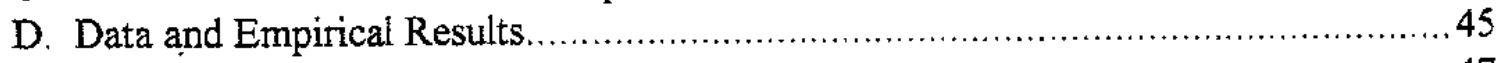
E. Conclusions. 


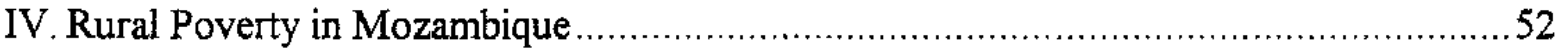

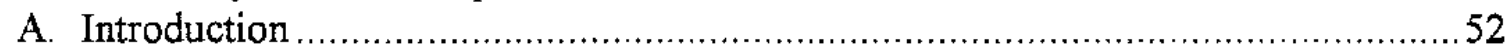

B. The Characteristics and Causes of Rural Poverty ...............................................53

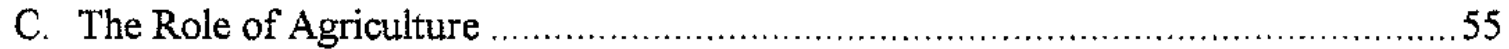

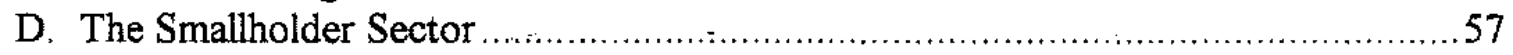

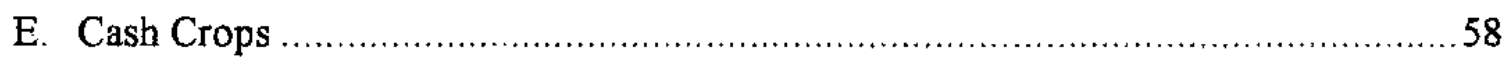

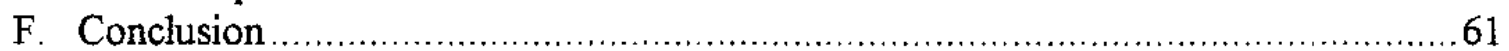

Boxes

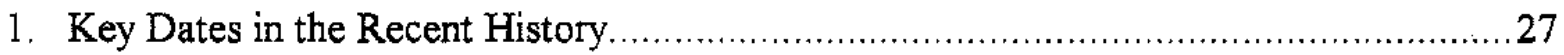

2. Rural Livelihood Strategies in Ndixe Village, Maputo Province ...................................63

Figures

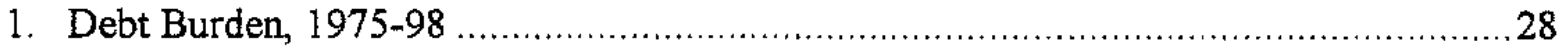

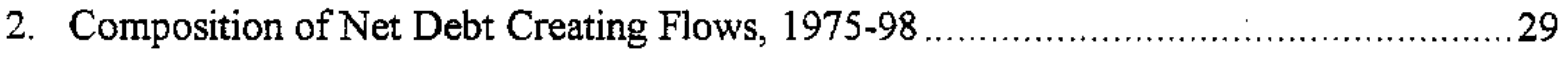

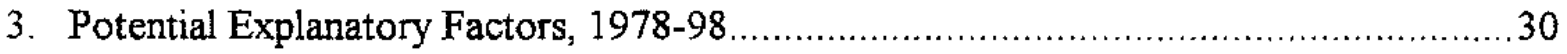

4. Composition of Foreign Financing by Creditor and Sources ..................................31

5. Assistance Under Traditional Rescheduling Mechanisms, 1978-98 .............................32

6. Real Effective Exchange Rate and its Determinants,

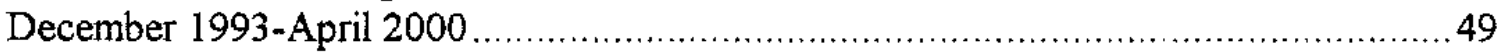

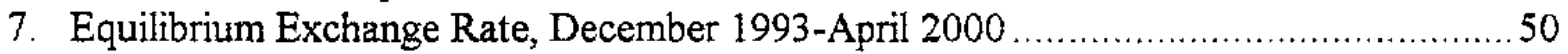

Text Tables

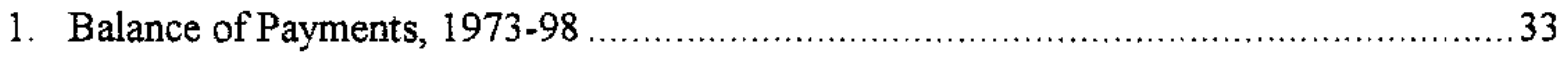

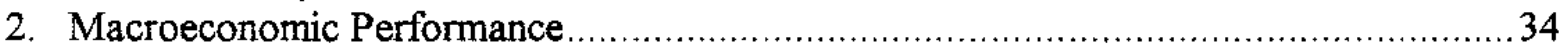

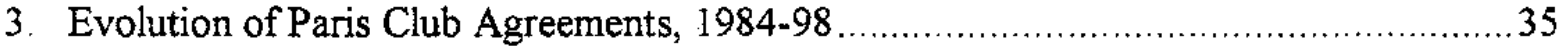

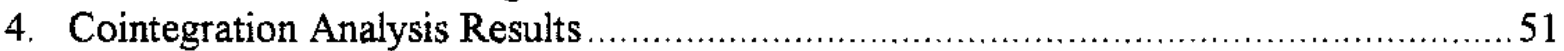

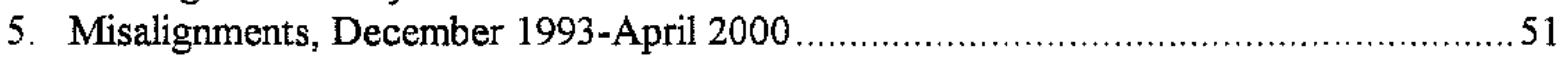

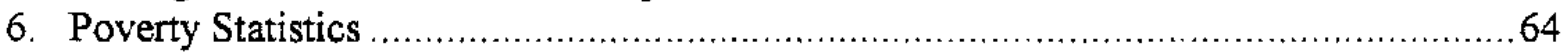

7. Poverty Characteristics of the Rural andUrban Poor, compared with the

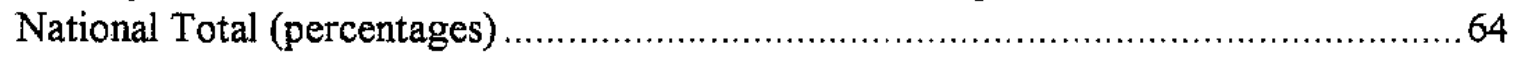

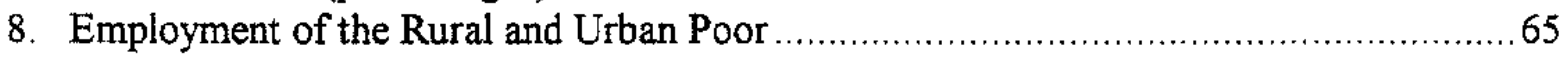

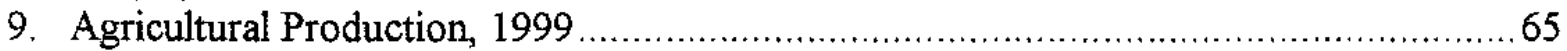

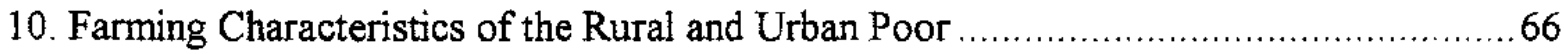


Statistical Appendix Tables

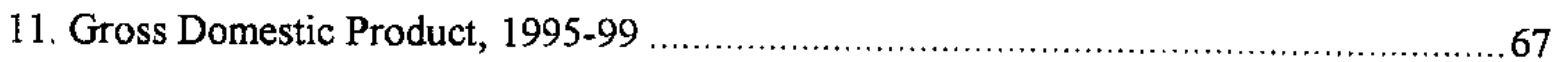

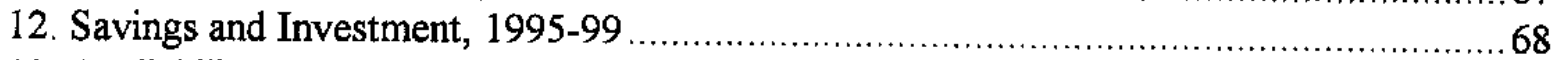

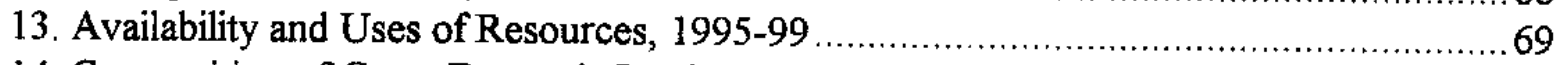

14. Composition of Gross Domestic Product, 1995-99 ............................................... 70

15. Production of Major Marketed Crops, 1994/95-1998/99 ….......................................71 71

16. Commercialized Crop Production by the Family Sector, 1994/95-1998/99 …...............72

17. Prices of Major Marketed Crops, 1994/95-1998/99 ............................................... 73

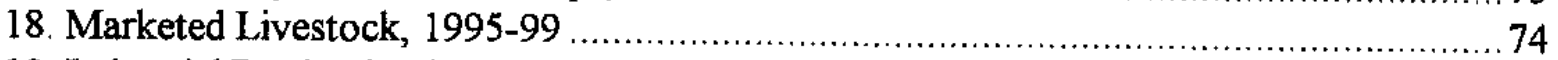

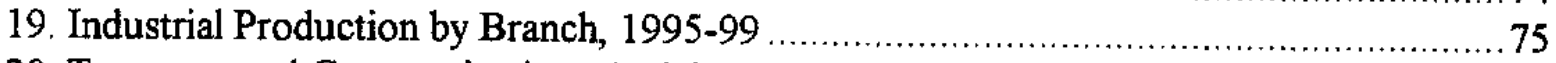

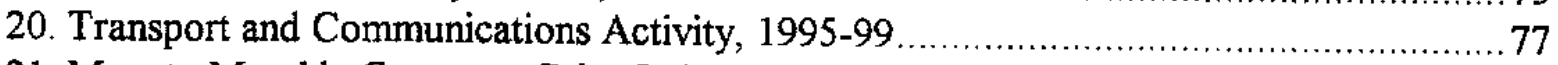

21. Maputo Monthly Consumer Price Index, December 1989-October $2000 \ldots \ldots \ldots \ldots \ldots \ldots \ldots . . .78$

22. Major Consumer Price Index (CPI) Categories, December 1997-December 1999 _........ 79

23. Minimum Agricultural Producer Prices, 1995/96-1999/2000 …................................ 80

24. Administered Prices of Petroleum Products, 1995-99 …............................................ 81

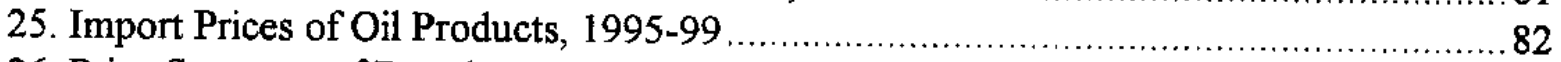

26. Price Structure of Petroleum Products, Fourth Quarter 1999 …................................... 83

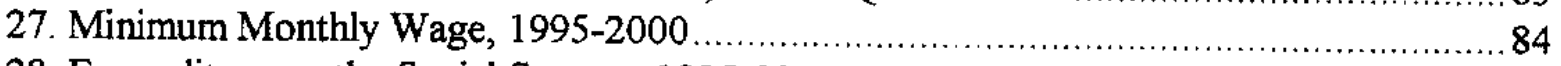

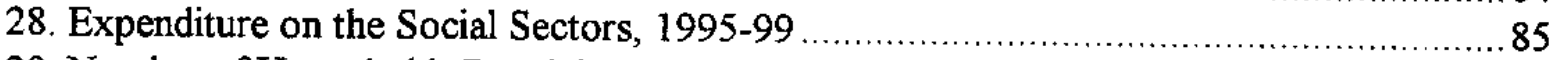

29. Number of Households Receiving Food Subsidy Assistance, March 1996-December 1999

30. Budget Subsidies to Enterprises, 1995-99 ……

31. Government Finances, in Billions of Meticais, 1997-99 ........................................8 88

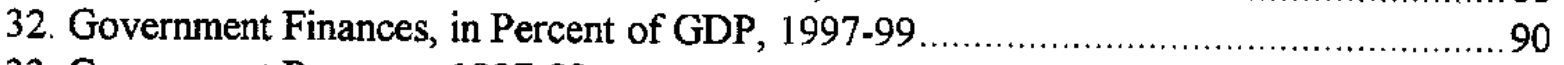

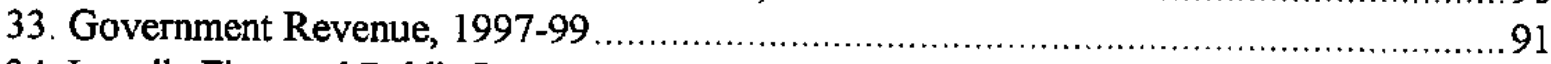

34. Locally Financed Public Investment by Sector, 1995-99 …..................................92

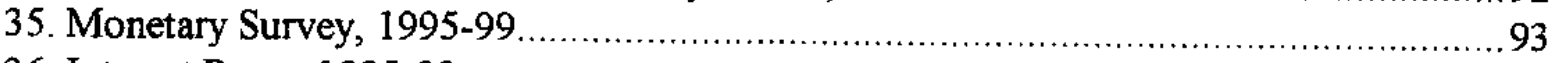

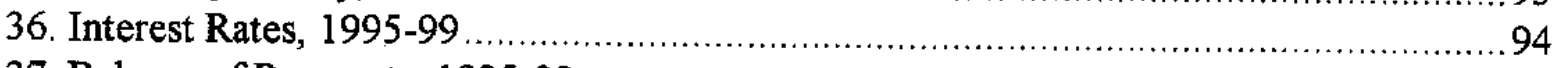

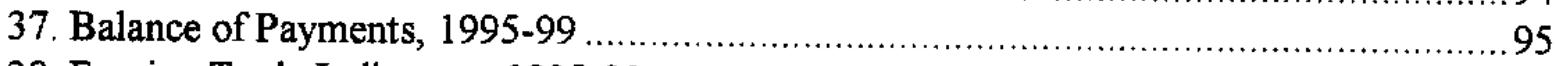

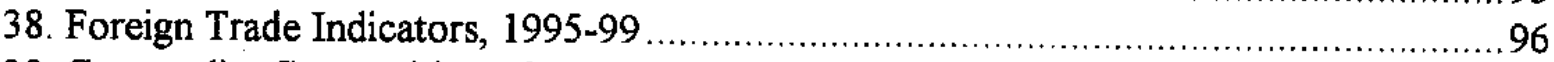

39. Commodity Composition of Exports, 1995-99 _................................................... 97

40. Exports by Country of Destination, 1995-99 ……................................................ 98

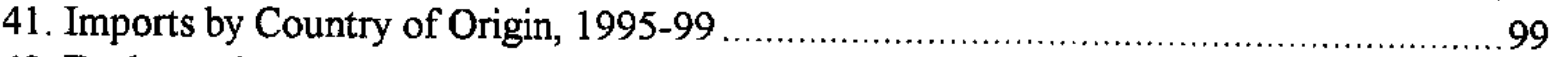

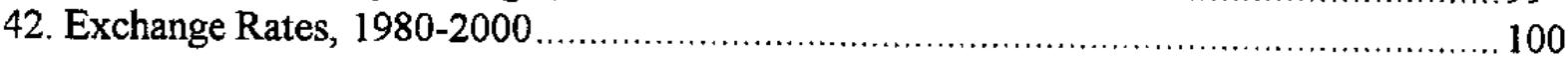

Appendix

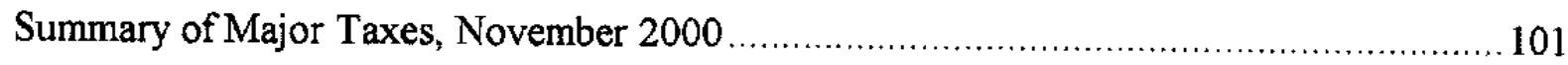


Mozambique: Basic Data

1995

1996

$1997 \quad 1998$

1999

(In billions of meticais)

GDP at current market prices

Total consumption

Gross investment

Resource gap (net imports) 1/

Real growth rates

Gross domestic product

Private consumption

Public consumption

Gross investment

Exports 1/

Imports 1/

Changes in prices

GDP deflator

Consumer prices (average) $2 /$

Consumer prices (end of period) $2 /$

Government finances

Total revenue

Total expenditure and net lending Of which

current expenditure

capital expenditure

Current deficit (surplus + )

Overall deficit before grants

Financing:

External grants

Net external borrowing

Domestic financing

Money and credit

Net foreign assets

Net domestic assets

Credit to the government (net)

Credit to the economy

Broad money (M2)

$\begin{array}{rrrrr}21,590 & 32,719 & 40,554 & 46,427 & 50,827 \\ 21,353 & 33,317 & 40,183 & 43,101 & 47,425 \\ 6,041 & 6,845 & 7,427 & 10,887 & 16,558 \\ 7,561 & 13,155 & 14,041 & 11,268 & 12,071\end{array}$

(Annual percentage changes)

$\begin{array}{rrrrr}4.3 & 7.1 & 11.1 & 11.9 & 7.3 \\ -1.1 & 9.7 & 7.0 & 5.7 & 6.7 \\ -49.1 & 12.6 & 21.0 & 8.5 & 9.4 \\ 20.9 & -8.4 & 1.9 & 41.1 & 47.1 \\ 8.1 & 24.6 & 10.7 & 10.7 & 16.4 \\ -22.8 & 6.5 & -3.2 & 10.2 & 43.3\end{array}$

53.1

54.4

54.1

$$
44.6
$$$$
16.6
$$

(n)

(In billions of meticais)

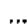

$\cdots$

$\ldots$

,

..

...

$\ldots$

... 4,272

... 4,816

... 351 $\cdots$

$\cdots$

$\begin{array}{rrrr}1.5 & 11.6 & 2.4 & 2.0 \\ 4.6 & 6.4 & 0.6 & 3.1 \\ 6.6 & 5.8 & -1.3 & 6.2\end{array}$

$\begin{array}{llll}\ldots & 4,623 & 5,324 & 6,207\end{array}$

$\begin{array}{llll}\cdots & 9,498 & 10,141 & 12,815\end{array}$

$5,268 \quad 6,332$

4,575

6,001

$56 \quad-125$

$+\cdots$

$-4,736$

$-4,923$

$-6,828$

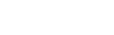

$\begin{array}{rrrr}\ldots & 3,705 & 3,818 & 6,035 \\ \ldots & 2,329 & 2,172 & 910 \\ \ldots & -1,298 & -1,067 & -117\end{array}$

$\begin{array}{rrrrr}-3,519 & -1,619 & -869 & -253 & 725 \\ 8,439 & 7,578 & 8,282 & 8,973 & 11,059 \\ -1,636 & -3,087 & -4,429 & -5,612 & -5,616 \\ 2,536 & 3,565 & 5,406 & 6,725 & 8,720 \\ 4,920 & 5,958 & 7,414 & 8,720 & 11,785\end{array}$


Mozambique: Basic Data (continued)

\begin{tabular}{|c|c|c|c|c|c|}
\hline & 1995 & 1996 & 1997 & 1998 & 1999 \\
\hline Money and credit (growth rates) & \multicolumn{5}{|c|}{ (Annual percentage changes) } \\
\hline Credit to the economy & 48.2 & 40.6 & 51.6 & 24.4 & 29.7 \\
\hline M2 & 54.7 & 21.1 & 24.4 & 17.6 & 35.1 \\
\hline Balance of payments & \multicolumn{5}{|c|}{ (In millions of U.S. dollars) } \\
\hline Trade balance & -553 & -556 & -530 & -573 & .929 \\
\hline Exports (f.o.b.) & 174 & 226 & 230 & 245 & 271 \\
\hline Imports (c.i.f.) & -727 & .783 & -760 & -817 & $-1,200$ \\
\hline Services (net) & -124 & -90 & -81 & .176 & -275 \\
\hline Receipts & 292 & 314 & 342 & 333 & 353 \\
\hline Interest due & -144 & -148 & -147 & -163 & 197 \\
\hline Other payments & -272 & -256 & -276 & -346 & -826 \\
\hline Unrequited official transfers & 339 & 225 & 313 & 313 & 434 \\
\hline Current account, including grants & -338 & .422 & -298 & -436 & .770 \\
\hline Capital account & 64 & 248 & 181 & 263 & 613 \\
\hline Foreign borrowing & 282 & 347 & 316 & 300 & 472 \\
\hline Amortization & -264 & -172 & -201 & -249 & -240 \\
\hline Direct investment (net) & 45 & 73 & 64 & 213 & 382 \\
\hline \multicolumn{6}{|l|}{ Short-term capital and errors and } \\
\hline omissions (net) & 10 & 133 & -20 & -31 & -86 \\
\hline Overall balance & -264 & -41 & -98 & -204 & -243 \\
\hline Financing & 264 & 41 & 98 & 204 & 243 \\
\hline Bank of Mozambique (increase -) & -31 & -173 & -148 & -77 & .51 \\
\hline Of which : use of IMF credit (net) & -14 & -14 & 20 & 10 & -3 \\
\hline Net change in arrears (increase + ) & 174 & -49 & $-3,932$ & 20 & -762 \\
\hline Debt relief & 121 & 263 & 4,178 & 261 & 1,055 \\
\hline \multicolumn{6}{|l|}{ Gross international reserves } \\
\hline Total, end of year & 255 & 383 & 532 & 625 & 669 \\
\hline In months of imports of goods and nonfactor services & 3.0 & 4.8 & 6.8 & 7.0 & 5.2 \\
\hline \multicolumn{6}{|l|}{ External public debt } \\
\hline \multicolumn{6}{|l|}{ Debt service ratio (in percent of exports) } \\
\hline Before HIPC Initiative assistance (Naple terms) & 74.0 & 47.4 & 24.8 & 20.0 & 26.1 \\
\hline After HIPC Initiative assistance & $\cdots$ & $\ldots$ & $\cdots$ & $\ldots$ & 15.3 \\
\hline Exchange rate (average, Mt./US\$) $3 /$ & 8,890 & 11,294 & 11,546 & 11,850 & 12,689 \\
\hline
\end{tabular}


Mozambique: Basic Data (concluded)

IMF data (as of October 31, 2000)

Date of membership

Quota

Intervention currency

Market exchange rate

SDR equivalent

Total Fund holdings of meticais

Fund credit

Poverty Recuction and Growth Facility

Hoidings of SDRs

Social and demographic indicators
Septenber 24, 1984

SDR 113.6 million

U.S. dollar

Mt $16,244=$ USS 1

Mt 9,257.5 = SDR I

SDR 113.6 million

SDR 166.11 million

SDR 166.11 million

SDR 0.05 million

1970-73 1980-85

Most

Recent

Estimates

1992-98

Reference

Low-Income

Group

1992-98
GNP per capita (U.S. dollars) $4 /$

Area (thousand sq. $\mathbf{k m}$.)

Percontage agricultural

Population

Total population (millions)

Rate of growth (percent)

Urban (percent of total)

Population density (per sq. km.)

Vital statistics

Life expectancy at birth (years)

Infant mortality (per thousand live births)

Health and nutrition

Population per physician (thousands)

Immunization rate (percent under 12 months)

Measles

DPT

Access to safe water (percent of population)

Education

Hlliteracy rate (percent age 15+)

Gross pzimary school enrollment rate (percent of

respective age group)

\begin{tabular}{rrrr}
$\ldots$ & 250 & 230 & 520 \\
802 & 802 & 802 & $\ldots$ \\
59 & 59 & 60 & $\ldots$ \\
& & & \\
10.5 & 13.5 & 16.9 & $2,035.6$ \\
2.2 & 2.3 & 2.1 & 1.7 \\
8.6 & 19.4 & 38.0 & 31.0 \\
13.1 & 16.8 & 21.1 & $\ldots$ \\
& & & \\
42 & 44 & 47 & 63 \\
168 & 133 & 134 & 69 \\
62 & 50 & & $\ldots$ \\
$\ldots$ & 39 & $\ldots$ & 80 \\
$\ldots$ & 29 & 70 & 82 \\
$\ldots$ & 9 & 61 & 74 \\
93 & 72 & 24 & 32 \\
$\ldots$ & 62 & 60 & 108 \\
& & 71 & \\
\hline
\end{tabular}

Sources: Mozambican authorities, and staff estimates.

1/ Goods and nonfactor senvices.

2/ In 2000 , the consurner price index was rebased on weight's stemnning from the 1998 census.

3/ Official rate in 1996; market rate thereafter.

4/ Most recent estimates for Mozambique refers to 1999. 


\section{Selected Public Finance Issues ${ }^{1}$}

\section{A. Revenue Issues}

1. Over the past few years, Mozambique has made considerable progress toward establishing a modern and effective tax system through wide-ranging reforms in a number of key areas. The introduction of a value-added tax in mid-1999 was successful and will provide the basis for shifting the focus of revenue collections from imported goods to domestic transactions over the medium term. The first phase of reforms in customs procedures, as initiated in the mid-1990s, has been recently concluded, with overall satisfactory results. Some steps have already been taken to optimize the current system of fiscal incentives, and further action is planned in this area to reduce revenue loss while safeguarding the objective of fostering foreign and domestic investment.

2. Despite these important steps, more will need to be done in the near future to create the basis for the sustained increase of revenue needed to support high government outlays for poverty alleviation and rehabilitation of infrastructure. The government has requested assistance from the Fund and a bilateral donor to conduct within the next few months a comprehensive review of options to further strengthen the tax system and tax administration. The main objective of future reform steps will be to broaden the tax base while maintaining a moderate tax burden for individuals and corporations. To this end, the review will include an assessment of direct taxation, options to strengthen tax administration through improved controls of large taxpayers, and suggestions to improve cooperation between customs and the domestic tax authority. These measures will also help to prepare for the establishment of a central revenue authority in the next three-five years.

\section{Value-added tax}

3. The centerpiece of the reform of the indirect tax system was the introduction, in June 1999, of a value-added tax (VAT) and selective excise taxes that replaced the cascading turnover tax (imposto de circulação) and the broad-based consumption tax (imposto de consumo). The tax is levied at a unified rate of 17 percent, and exemptions are granted for some products, including basic food items and inputs into agricultural production. The tax is collected by the National Directorate for Taxes and Audits (DNIA) on domestic transactions, and by the National Customs Directorate (DNA) on imported goods. Exports are eligible for refunds of VAT paid on their inputs.

4. Overall, the introduction of the VAT has been successful: revenue collected is in line with projections and is expected to reach 5.1 percent of GDP in 2000, equivalent to 40 percent of overall tax collections. The number of taxpayers included in the VAT system increased to 22,300 (October 2000), including 9,500 exempt taxpayers that are being

\footnotetext{
${ }^{1}$ This section was prepared by Alvaro Manoel and Arnim Schwidrowski.
} 
monitored to facilitate the cross-checking of information. The VAT Central Services, initially established outside the regular tax administration, is now integrated into the DNIA, and equipped with qualified staff and modern installations and information systems. The implementation of adequate administrative rules and procedures, together with an extensive publicity and information campaign, has helped to allay the private sector's initial concerns regarding the complexity of the new tax, and the sector is now broadly satisfied with the system in place. Introduction of the tax was supported by technical assistance from the Fund and the Swiss State Secretariat of Economy (SECO), including through a long-term resident advisor.

5. There are, however, a few remaining issues that the government intends to address within the next few months, with technical support from the Fund and SECO. These include an acceleration in the processing of refunds; a strengthening of audit capacity; and further information and training efforts. Refunds to exporters have not been handled as expeditiously as mandated by the law (normally within 90 days), not only because of unduly complicated procedures and inadequate data processing systems but also owing to a lack of knowledge by private agents regarding the documentation to be presented and administrative steps to be followed. As of mid-September, only about 27 percent of requests for refunds had been paid, while about 30 percent had been rejected due to faulty documentation; meanwhile, the processing of another 15 percent had been suspended awaiting more complete information. The remaining cases were in the process of being audited or paid. On audits, despite the recruitment and training of a number of auditors in the past few months, the manpower and preparation of the audit department continues to be rather limited. Therefore, the government intends to hire and train a significant number of additional auditors in 2001-02. In addition, the DNIA has recently begun to cooperate with customs in cross-checking VAT information and has launched a series of on-site audits.

\section{Customs reform}

6. In light of the serious deficiencies in all aspects of customs management and controls that were reflected in a significant decline in duty and tax collections during the first half of the 1990 s, the government decided on a comprehensive customs reform in 1995 . Key elements of this reform were the hiring of a foreign private firm to manage customs; the creation of a special unit in charge of the overall customs reform; the introduction of preshipment inspection; and a significant reduction of duty rates and exemptions. The special reform unit (Unidade Técnica para a Reestructuração das Alfândegas, or UTRA) was created in 1995; more effective pre-shipment inspection arrangements were introduced in March 1996; a new Customs Code, with lower rates and exemptions, was published in October 1996; and the selected private company started to manage the customs in January 1997.

7. Progress in customs reform at the end of the three-year management contract with the private firm has been on the whole positive. The reform included (i) modernization and integration of the largest parts of customs legislation into one coherent body of laws and regulations (including the introduction of simplified customs declaration forms); (ii) the 
reevaluation and replacement, where necessary, of customs staff (to be concluded by December 2000); (iii) the simplification of the pay structure and its link to performance; and (iv) significant progress in computerizing customs procedures. In addition, since 1997, the private sector and other users have been participating in the Customs Higher Technical Council (CSTA) to discuss the progress of the customs reform project and trade-related policies in general. Finally, customs has been publicizing widely cases of fraud and corruption within its own ranks, together with the penalties applied to such cases.

8. Despite the overall good progress in implementing the reform, activities in some key areas had not yet come to a close at the end of the management contract in early 2000. Therefore, the government decided to sign another three-year contract with the same firm. However, with a view to returning customs management gradually into Mozambican hands, the firm's staff will now move into an advisory role and disengage itself from the direct management of the day-to-day business of customs. In line with this overall objective, the hired company will continue to train local staff so as to allow a transfer of responsibilities to them, as well as to improve existing information and control systems. Particular attention will need to be paid to strengthening internal control functions and the integrity of newly trained local staff, so as to avoid a resurgence of corruption. The use of random postshipment inspections will also be an important element in this strategy.

\section{Fiscal incentives}

9. Over the past few years, Mozambique has made progress toward establishing general conditions that help attract foreign direct investment and promote the activities of the domestic private sector, including the achievement of relative macroeconomic stability; some rehabilitation of basic infrastructure and improvement in the quality of human capital through better health and education services; and the establishment of a simple and transparent tax system, with generally moderate rates.

10. The government felt, however, that additional fiscal incentives were needed to offset the persisting deficiencies in human capital and basic infrastructure that might be inducing foreign investors to prefer other countries in the region. Therefore, a number of fiscal incentives have been established not only to promote overall foreign and domestic investment (e.g., the Fiscal Incentives Code, 1993, and the Decree on Industrial Free Zones, 1999), but also to develop certain regions of the country (Zambezi Valley) and certain sectors (energy, hotels and tourism, sugar, car rental activities). In addition, a number of incentives are in place that are not linked to industrial activity-for example, incentives for Mozambican miners in South Africa, political parties, members of parliament, and cultural and educational activities. Fiscal incentives are largely granted in the form of holidays from direct taxation and exemptions from import duties and the VAT.

11. The desire to promote foreign and domestic investment through fiscal incentives contrasts with the need, as recognized by the government, for a significant and sustained increase of tax collections over the medium term, aimed at reducing the country's dependence 
on aid and mobilizing the resources needed to reduce poverty and rehabilitate basic infrastructure. Therefore, the government has embarked on a comprehensive review of the current system of fiscal incentives, with a view to optimizing it. Key aspects of this review are an evaluation of the cost-effectiveness of the incentives being granted; an assessment of the administrative burden imposed by them; and an examination of the need to curtail the tax evasion that may well exist under the current rules. ${ }^{2}$

12. There is considerable scope to improve the current system, taking into account the lack of effectiveness of the main instruments in use in promoting additional investment; the failure of the different schemes to follow the same basic principles; and the difficulties in controlling projects that benefit from one or more of the incentive schemes. Exemptions or reduction of corporate income tax for a period of time come at a high cost in terms of revenue forgone, tend to favor projects that expect to generate high profits in the short run, and thus may not contribute as much as expected to long-run development objectives. Exemptions from import duties create a bias against domestically produced goods and services; and exemptions from the VAT are largely ineffective as taxes paid on inputs are deductible and refundable for exports.

13. The first concrete steps to optimize and streamline the current system of fiscal incentives have already been taken, including a clearer definition of industrial free zones as geographically demarcated areas, so that they can be effectively controlled by customs; the requirement of a technical assessment from both the DNA and DNIA prior to the approval of new investment incentives; and improved regulations to control and audit goods in domestic circulation. Importantly, the government envisages a comprehensive review of the Fiscal Incentives Code by 2001, which is expected to result in important revenue gains over the next few years.

\section{B. The Expenditure Process}

\section{Institutional framework}

14. During 1997-98, the government implemented important improvements in the budgetary framework. The Budgetary Framework Law and associated regulations are very comprehensive in establishing deadlines and formats for crucial aspects of budget preparation and execution such as (a) initial budget limits from the Ministry of Planning and Finance (MPF); (b) submission of budget proposals by line ministries; (c) final budget presentation to the National Assembly; (d) publication of the budget; and (e) reporting and control procedures.

\footnotetext{
${ }^{2}$ In 2000, two technical studies of the current system of fiscal incentives were carried out at the request of the government, one of them by the Fund's Fiscal Affairs Department.
} 
15. Within the MPF, the Directorate for Planning and Budget (DNPO) is responsible for expenditure programming and the preparation and monitoring of the budget; the Accounting Directorate (DNCP) is in charge of accounting; and the Treasury Directorate (DNT) manages treasury operations, in particular disbursements from treasury accounts to budgetary institutions and debt management. Controls are executed by the General Finance Inspectorate (IGF), reporting directly to the Minister of Planning and Finance, and the Administrative Tribunal, an independent constitutional body reporting to the National Assembly.

16. The Framework Law unified investment and recurrent budgets and established a new system of budget classification. However, the new budget classification still has some important shortcomings. Thus, the functional classification distinguishes only fourteen sectors (e.g. education, health, defense, etc.), and there is no classification by program (e.g. by policy goals and objectives). A centralized monitoring of the execution of certain specific spending categories (such as poverty-related expenditures) is therefore difficult within existing accounting and reporting procedures. It should be noted, however, that a number of line ministries and agencies use more disaggregated classifications in their budget planning and execution, responding mainly to donor requests for such information in tracking aid-funded projects. Availability of such information should provide a good basis for moving toward a more detailed accounting for some key sectors.

17. Although the Framework Law calls for unity and universality of the budget-all gross revenues and expenditures should be included, approved, and reported - the annual budget has so far not provided a comprehensive picture of general government revenue, expenditure, and financing. Many activities have been undertaken outside the budget, including those relating to (a).a substantial part of foreign aid; (b) retained fees or other revenues by ministries and budgetary units; and (c) extrabudgetary funds such as the Agrarian Fund, the Road Maintenance Fund, and resources of the National Social Security Institute.

18. Due to perceived weaknesses in Treasury management that could delay the flow of external resources to targeted projects, a number of donors have been channeling their financial support directly to the executing agencies, bypassing the Treasury. Such practices, although gradually diminishing, are still being followed for a sizable share of foreign-funded investment spending, thus exacerbating the difficulties in tracking total government spending. Other problematic consequences include: (a) the distinction between capital and current expenditures is blurred; (b) government budget plans, which include some estimate of overall donor funds, are incompatible with budget outturn data; (c) expenditure data provided by donors, or captured by the public expenditure accounting systems, may not correspond to general deadlines established in the legal budget framework; and (d) the presence of substantial in-kind assistance, especially technical assistance, is difficult to capture in fiscal data.

19. Overall, despite a sound legal framework, the budget system in Mozambique is deficient in terms of its comprehensiveness (complete coverage of government operations) and its transparency (useful classification and possibility to connect policies and expenditure 
through a program structure). To remedy this situation, the government intends to incorporate gradually all extrabudgetary activities into the budget, as well as take into consideration quasifiscal activities and contingent liabilities.

\section{Budget preparation}

20. While a medium-term fiscal outlook has been prepared since 1998 and is being increasingly used as an instrument of programming, projections of budget revenue and expenditure are still largely based on past patterns. Since there is no recording and reporting of commitments at the central level, expenditure projections are not based on such information. Furthermore, past expenditure patterns are generally of limited use for future budgeting, because they are too broadly aggregated (see above). Meanwhile, investment programming in the annual budget has benefited from the rolling three-year investment program that has been produced since 1990. More than an investment budget, this investment program is a comprehensive portfolio of aid-financed projects encompassing more than 2000 projects, including at the provincial level.

21. Responsibility for the preparation of the budget lies with the MPF, in particular the budget directorate DNP, with input from line ministries and some autonomous institutions. Budgetary institutions and the MPF follow the classic main steps in budget preparation. First, the MPF establishes sectoral budget limits (recurrent and investment expenditure) by the end of May. Second, the line ministries and provinces discuss the limits and prepare their bids during June-July. Third, in response to the original budget limits, line ministries submit a detailed budget to the MPF by the end of July (as regards investment bids, ministries' submissions are prepared on a project-by-project basis). Fourth, the process moves to the consolidation of the budget by the MPF through reviewing and negotiating with line ministries their budget requests, ultimately leading to consolidated expenditure estimates. Finally, the budget is submitted to the National Assembly for approval, usually in November.

\section{Budget execution and reporting}

22. Once the National Assembly approves the annual budget, ministries are authorized to spend money, consistent with the legal appropriations for each line item. A carryover period of three months exists. This rather long carryover period means that during the first quarter of each fiscal year, expenditure may still be imputed to the previous year's budget, which only lengthens the time needed to prepare and audit the public accounts.

23. The annual budget regularly envisages a contingency that can be used for unforeseen expenditure, for example in the event of natural disasters. Spending against this contingency, as well as additional spending outside the budget limits, can be authorized by the Minister of Planning and Finance on a provisional basis but must be approved later by Parliament through a supplementary budget. In addition, adjustments to nominal spending limits can be proposed by the Minister of Planning and Finance to Parliament when actual inflation exceeds the projected increase of prices. 
24. Budget financial execution follows a very simple procedure where the MPF keeps control of monthly disbursements, and the budgetary institutions (line ministries and autonomous institutions) are in charge of carrying out the purchase of goods and services, verification, payment, and reporting back to the MPF.

25. As regards non-salary expenditures, budgetary institutions are allowed to spend up to one-twelfth of their annual budget allocations each month. A contingency reserve of about 10 percent of the current budget and 20 percent of the investment budget is kept by the MPF to cover unforeseen expenditures. At the beginning of the year, and net of these reserves, the MPF disburses two-twelfths of the annual allocation. The resources are transferred to the budgetary institutions' bank accounts. Every month, the budgetary institutions submit spending reports and banking statements to the MPF, whereupon a new monthly disbursement is effected. In the case of salary expenditures, payments are made directly at the central level against the monthly salary bills prepared by line ministries and budgetary institutions.

26. Although these cash management arrangements have facilitated the observance of fiscal targets, they imply some important drawbacks, such as the existence of hundreds of banking accounts owned by the budgetary institutions where up to one-twelfth of annual budget resources are kept idle throughout the year while the Treasury may at the same time suffer from liquidity bottlenecks. The consolidation of these accounts into one single treasury account for revenues and expenditures should therefore be part of any additional reform in the public expenditure management system.

27. Mozambique is a case where internal and external reporting could be improved quickly. Internal reports on budget execution are prepared monthly by line ministries and conveyed to the MPF, which consolidates the information into a very broad functional, economic, and administrative classification. Since the beginning of 2000 , a quarterly budget execution report has been published within two months of the end of each quarter. To improve budgetary reporting, the government accounting system should be expanded to provide for more detail in different classifications and to enable the tracking of expenditures by program and/or project; also, the frequency of budget execution reports could be raised to monthly in the future. Other improvements might include a more systematic registration of all steps of budget execution.

28. The Administrative Tribunal - an autonomous institution-is responsible for external audit in Mozambique. Its president is appointed by the President of the Republic and confirmed by the National Assembly. The Tribunal gives its opinion on the final accounts and submits them to the National Assembly. It also judges and audits the accounts of public enterprises and companies with majority government shareholding and carries out special audits. In mid-2000, for the first time since independence, the Administrative Tribunal examined the consolidated accounts of the 1998 budget and submitted a report to the National Assembly that was subsequently published. According to the current legislation, the time frame between the end of the fiscal year and the publication of the Tribunal's opinion on the final accounts is twenty months. A lag of this length in the auditing of final accounts can 
undermine their information value. Public accountability in Mozambique could therefore be enhanced if the time limits given to the Ministry of Planning and Finance for preparing the final accounts (currently twelve months) and to the Administrative Tribunal for the preparation of its report (currently eight months) were significantly shortened.

\section{Outlook}

29. Despite substantive progress toward strengthening the budget process in all its phases over the past few years, the authorities recognize the need for further reforms, and a number of initiatives are under way. The government will draft a new accounting law by March 2001 that will help to provide a more disaggregated spending classification and to record more systematically all stages of the spending process. As broad-based accounting reforms will take some time to implement fully, the government is establishing an interim system to track poverty-related spending. On the budget planning side, efforts are under way to link the medium-term fiscal outlook more closely to the preparation of the annual budget and, importantly, integrate the costed poverty-reduction strategy into this framework. With the help of bilateral technical assistance, reforms in treasury operations have begun, including the consolidation of accounts. In addition, the government is committed to universalizing the budget coverage by gradually integrating off-budget operations. Finally, the government will conduct a Public Expenditure Review in cooperation with the World Bank and bilateral donors that will cover all budgeting processes and the efficiency of public expenditure, focussing on sectors that are considered key for poverty reduction. 


\section{Why Did Mozambique Fall INTo Debt? Mozambique's DeBt BURDEN IN Historical Perspective ${ }^{3}$}

\section{A. Introduction}

30. Mozambique expects to reach soon the completion point under the enhanced HIPC Initiative (Initiative for Heavily Indebted Poor Countries). This is an opportune time to take stock of its experience, so as to avoid a recurrence of debt problems and to draw lessons that may be useful also for other countries. This section asks the question of why Mozambique accumulated unsustainable debt. The attempt to answer it draws on three basic pieces of information: (i) a chronology of the main political and economic events in the history of Mozambique since independence, (ii) an estimated balance of payments from 1973 to 1998, and (iii) an account of traditional debt-relief mechanisms. The following subsections present a measure of Mozambique's external debt burden from 1975 to 1998 - from independence to the decision point under the original HIPC Initiative-and discuss potential explanatory factors of the evolution of the debt burden over time. Conclusions and some policy implications are drawn in the final section.

\section{B. Mozambique's External Debt Burden}

31. The earliest official estimate of Mozambique's nominal stock of public gross external debt exists for 1984, the year of the first Paris Club rescheduling; it put the debt at about US $\$ 2.4$ billion, more than ten times the total value of export of goods and services in that year, or about 50 percent of GDP. In order to understand the causes of the sharp buildup of debt, a balance of payments table from 1973 to 1998 was compiled based on the Fund's background papers on recent economic developments (REDs) on Mozambique, official historical statistics, and staff estimates (Table 1). A measure of the total nominal stock of net external debt was then obtained by cumulating net debt-creating balance of payments flows from 1975 onward. $^{4}$

32. A net rather than a gross concept of debt is usually analyzed when a country is known to have both assets and liabilities. While the precise figures are not known, this appears to

${ }^{3}$ This section was prepared by Alessandro Rebucci.

${ }^{4}$ The annual flow of nominal net debt-creating liabilities used is defined as new borrowing scheduled amortization + increase in short-term debt + decrease in net foreign assets of the central bank + increase in arrears + debt relief - debt forgiveness. Note also that the measure constructed does not distinguish between private and public sector debt because of the lack of historical data on private sector debt. The stock of medium- and long-term debt of the private sector, however, was very small until recently. Estimated short-term private capital flows are lumped together with errors and omissions. 
have been Mozambique's position at the time of independence. More generally, other sources of balance of payments financing than external debt may have been used while the debt was building up, so that looking only at gross debt may lead to over- or underestimating the underlying imbalances. A set of internally consistent figures within a well-defined accounting framework should also be more reliable than the analysis of a single series in isolation. The measure of nominal net external debt constructed in percent of exports of goods and services (as a proxy for the country's ability to repay the debt) and GDP (as a proxy of the economy's size), together with annual flows, is reported in Figure 1. Figure 2 shows the composition of these flows by type of financing instrument.

33. Two important facts emerge from these figures. First, it was not until 1978-79 that Mozambique started to accumulate substantial amounts of external liabilities, as the drawdown of foreign reserves was sufficient to finance the current account deficit during the years immediately after independence (Figure 2 and Table 1). Second, while the nominal stock of net debt kept rising throughout the period considered (Table 1), net debt in percent of exports of goods and services peaked as early as 1986-87, and in relation to GDP in 1993-94 (Figure 1). Mozambique's debt burden, therefore, was accumulated primarily during the period 1978-93 - the period of the civil war.

34. The civil war, however, may not have been the only cause of the rise in Mozambique's debt burden, and other demand and supply factors might have contributed to the buildup of debt. Brooks and others (1998) and Baltazar and Associates (1999), for instance, find that, in addition to political factors such as civil war and social strife, external (terms of trade and weather-related) shocks, lack of adjustment and reforms, and creditors' financing and refinancing policies all help explain the buildup of debt observed in many low-income developing countries over basically the same period. ${ }^{5}$ The next four subsections analyze each of these potential explanatory factors, after a brief discussion of the initial conditions at the time of independence.

\section{Initial Conditions}

35. Mozambique's war of independence started in 1964, and independence was reached in June 1975, after the Portuguese revolution left the colonial administration in disarray in April 1974 (Box 1). The level of economic development in colonial Mozambique was low even by African standards (Bruck, 1997). GDP per capita is estimated at US\$200 in 1973-the last year of colonial rule (Leite and others, 1998).

\footnotetext{
${ }^{5}$ Baltazar and Associates (1999) argue that, in addition to the factors listed, high import requirements, coupled with low domestic saving rates and a high failure rate of foreignfinanced investment projects, explain the debt buildup in the specific case of Mozambique.
} 
36. The stock of gross debt owed to Portugal was reportedly positive, albeit small in relation to exports, at the end of the $1960 \mathrm{~s}$. Miscellaneous press reports put the nominal stock of gross debt at less than US $\$ 100$ million in 1975, while the stock of foreign reserves inherited from the Portuguese administration is estimated at more than US\$500 million in $1975 .^{6}$

37. Neither the war of liberation nor the status of the public finances inherited from the Portuguese administration, therefore, appear to be good candidates to explain the sharp buildup of debt during the first few years after independence. Independence, however, brought about a first major shock that affected Mozambique's economy and balance of payments for many years to come: a large loss of human capital due to the sudden departure of the Portuguese settlers who were occupying the vast majority of the qualified positions in the economy, including in the important service sector, which traditionally had been in surplus.

\section{External Shocks}

\section{Terms of trade shocks}

38. Sudden terms of trade changes and poor macroeconomic policy responses to these shocks are widely regarded as a major source of external vulnerability and imbalance for lowand middle-income developing countries because of their dependence on the export of primary commodities. Mozambique's estimated terms of trade are reported in Figure 3 and Table 1, together with total exports of goods and services.

39. A terms of trade decline totaling about 10 percent between 1975 and 1980 affected Mozambique's balance of payments and real income negatively during this period. However, developments in subsequent years suggest that terms of trade changes were not the main driving force behind the buildup of debt. The debt burden rose almost fourfold between 1982 and 1986 despite a 40 percent improvement in the terms of trade over the same period, equally split between higher export prices and lower import prices. Hence, the sharp decline of export values from 1981 to 1985 reflects the collapse of export volumes rather than exogenous price shocks.

40. Indeed, during this period, the collapse of foreign revenues deriving from tourism, transit trade, and border workers was in part, if not mainly, affected by the civil war and the external political factors ultimately explaining the local conflict (Subsection $\mathrm{E}$ below). The sharp contraction in agricultural output, amply documented by CNP (1985) for both cash and subsistence crops, however, was related also to the lack of protection of property rightsbrought about by land nationalization immediately after independence--and the distortions of

\footnotetext{
${ }^{6}$ The reported figure for gross debt in 1975 is not fully consistent with official balance of payments statistics in subsequent years reported by CNP (1985). For simplicity, the nominal stock of gross debt in 1975 is set to zero in Table 1.
} 
price incentives imposed by economic planning - formally endorsed in 1977 (Hall and Young, 1997).

\section{Natural disasters}

41. Separate estimates of the balance of payments impact of the floods and droughts that periodically afflicted Mozambique during the period of the strongest debt buildup are not available. However, a simple account of the main events is enough to appreciate the contribution of this erratic factor:

The Limpopo and Incomati rivers flooded in eariy 1977-the worst flood in living memory - at that time-making some 400,000 people homeless and causing some US\$34 million worth of damage. The Zambezi flooded in early 1978, resulting in some US\$60 million worth of damage and affecting some of Mozambique's most fertile zones. Serious water shortages in some parts of the country (especially Inhambane) turned into full-scale drought in 1980, leading the government to make an urgent appeal for international food aid. By the end of 1980 the drought was seriously affecting about 1.5 million people in six of the country's ten provinces. (Hall and Young, 1997, p.106).

The 1980 drought, which reportedly lasted until 1983, was followed by floods in 1984-1985 and two other severe droughts in 1986-1987 and 1991-92, respectively (Box 1).

42. As a partial result of these natural shocks, but also, as noted above, because of other factors negatively affecting agricultural domestic supply, Mozambique's food balance soon went into structural deficit and did not recover until very recently, forcing the country to rely on food import to feed its people, and thereby continuing to add pressure to the balance of payments. It is estimated, for example, that imports of foodstuff averaged more than US $\$ 100$ million a year during the period $1980-84$, as compared to imports of other consumer goods of about US\$60 million per year over the same period.

43. While it is difficult to distinguish the contributions of terms of trade and weatherrelated shocks to the initial buildup of debt from those of other contributors, such as political or economic policy factors, the evidence suggests quite clearly that adverse weather conditions have been more important than adverse relative price movements in international commodity markets.

\section{E. Political Factors}

44. An opposition group to the Frente de Libertação de Moçambique (Frelimo) — which was to become Resistência Nacional Moçambicana (Renamo) in 1978-was set up in Mozambique in 1974 (Box 1). In March 1976, nine months after independence, Mozambique adhered to the UN embargo against the former Rhodesia and closed its northern borders at an estimated cost-resulting from the loss of transit trade, tourism, and migrant labor revenues- 
of about $£ 250$ million (Hall and Young, 1997, p. 106). ${ }^{7}$ An agreement with South Africa, whereby 60 percent of miners' remittances were transferred directly to the central bank in gold valued at the 1973 official price, was discontinued in 1978, depriving the government of a stable source of foreign exchange that had provided essential balance of payments financing during the previous years.

45. Zimbabwe's independence ended the UN embargo in 1979 but marked the beginning of a new phase of the civil war in Mozambique, which escalated in 1981-82 with major disruptions to the country's infrastructure, including particularly in the transport and communication sectors. Notwithstanding a nonaggression treaty signed with South Africa in 1984, the war saw its worst times in 1985-86. The holding of peace talks was announced only in 1989. The talks began in 1990 in Rome, eventually leading to a cease-fire accord in 1992.

46. The civil war and the external political factors related to the conflict are probably the most important contributors to Mozambique's accumulation of external debt. Mozambique's conflict, a low-intensity one from a military point of view but nonetheless a highly disruptive one from an economic and social point of view (Bruck, 1997), lasted almost 20 years, taking a heavy toll on the country's human and physical capital, disrupting export capacity, increasing import requirements, and damaging an already weakened social tissue (Hall and Young, 1997; Bruck, 1997; and Bruck, Fitzgerald, and Crigsby, 2000). ${ }^{8}$ In order to give a partial view of the quantitative importance of the impact of the war on the debt buildup, Figure 3 plots military expenditures in percent of GDP and as a share of total expenditure: cumulative military expenditure between 1980-the first year for which data are available - and 1992 amount to about 120 percent of GDP, as compared to a net stock of debt at the end of 1992 of about 200 percent of GDP. As discussed below, the availability of foreign financing from both the eastern and the western blocs of the cold war may have actually fueled the conflict and thus supported military expenditures. In any case, the association between military expenditure and debt is striking, and confirms the quantitative significance of the former for the rise of Mozambique's debt burden over and above the indirect economic costs of the conflict.

\footnotetext{
${ }^{7}$ Baltazar and Associates (1999) put the costs of the adhesion to the UN embargo at more than US\$1 billion. According to CNP (1985), the number of border workers dropped by more than 50 percent between 1975 and 1977.

${ }^{8}$ Mozambique's civil strife would best be described and understood as a local conflict in the context of a complex regional situation strongly affected, in turn, by the confrontation of global powers during the cold war era. Uncovering the links between the global and regional "causes" of the conflict and its local "effects" is clearly beyond the scope of this section. See Bruck (1997) and Bruck, Fitzgerald, and Crigsby (2000) for a thorough analysis of the economic effects of the war, and the references quoted therein for a wider perspective on the regional and global causes of the war.
} 


\section{F. Domestic Economic Policies}

47. Mozambique's macroeconomic performance since independence has undergone four distinct phases (Table 2): (i) the decolonization period (1974-76), characterized by a sharp output contraction without a major external imbalance; (ii) the period of strict adherence to economic planning (1977-81), in which output rebounded somewhat from the earlier decline and internal and external imbalances first developed; (iii) a period of economic crisis and financial collapse (1982-86); and finally (iv) a period of more lasting recovery (1987-98), characterized by the resumption of growth, the gradual decline of inflation, and an improvement in the external balance after grants.

48. Following the postindependence turmoil and consequent economic decline, the government, which up to that point had not pursued a systematic transformation of Mozambique into a centrally planned economy, embraced formally Marxism-Leninism and economic planning at Frelimo's Third National Congress in February 1977; by 1981, most large-scale economic activities had been brought under the state's control through successive waves of nationalizations (Hall and Young, 1997). At the same time, public investment projects reportedly worth about US $\$ 800$ million had been effected under the direction of the National Planning Commission in agriculture, industry, transport and communications, and construction.

49. Growth resumed during the period 1977-81, rebounding from its postindependence slump, supported by good weather conditions in 1979-80 after two years of floods, and further stimulated by public investments. However, domestic absorption soon hit capacity constraints, inflation accelerated, and an import growth of more than 30 percent per year pushed the current account into large deficits despite the recovery of exports (Table 2). Hit by a severe drought and the intensification of the civil war, the economy slowed in 1981 and contracted sharply in 1982. Meanwhile, it was becoming apparent that state-owned enterprises and farms were draining budgetary resources and undermining productivity, especially in agriculture and services. More important, from the narrow point of view of the sustainability of the debt, it was also becoming clear that the rate of return on investments previously financed by foreign borrowing was insufficient to repay the credits drawn.

50. The government reacted to deteriorating economic conditions by departing, as early as 1980 , from strict adherence to economic planning, on the one hand-including by denationalizing small-scale activities-and by trying to strengthen its relationship with the east, on the other hand-that is, by redirecting trade toward the former Soviet bloc and by applying for accession to the Council for Mutual Economic Assistance (CMEA). CMEA countries, however, were facing economic difficulties of their own at the turn of the decade, and Mozambique's application to the CMEA was refused in mid-1981 (Box 1). 
51. After failing to obtain substantial support from eastern countries and facing a large projected cereals deficit (due to the 1980-83 drought), a shortage of consumer goods more generally, a lack of equipment to wage the war, and fast-rising debt-service payments, ${ }^{9}$ the government introduced a rationing system in Maputo in 1981 and turned to the west for financial assistance. It launched a series of international appeals for food aid, applied for membership of the Fund and the World Bank in 1982, and requested its first rescheduling from the Paris Club of creditors, which was eventually granted in 1984. Meanwhile, the government also took its first steps toward embracing the principles of the market economy at the Fourth National Congress of Frelimo in 1983.

52. The limited emergency financial assistance, however, was not sufficient to avert an economic crisis that was going far beyond the inability to meet immediate food needs and debt-service payments, as evidenced by the government's action to tighten the rationing system in Maputo in 1983 and broaden it to cover the city of Beira in 1986 (Box 1). During the period 1982-86, GDP declined markedly, and the current account of the balance of payments kept registering enormous deficits; meanwhile, inflation remained subdued until prices started to be liberalized in 1987.

53. The government's response to the economic crisis came in the form of a comprehensive program of economic reforms, the Economic Rehabilitation Program, presented to the national assembly in 1987 with the financial support of the Bretton Woods institutions; a rescheduling agreement with the London Club of creditors; and the second Paris Club rescheduling (Box 1 and Table 3). ${ }^{10}$

54. The economy responded quickly to this strong reform effort, and growth resumed during 1987-93, accompanied by a sharp export recovery (Figure 3). This trend accelerated after the war ended in 1993. Meanwhile, much higher grant financing (close to 20 percent of GDP on average during 1987-93) was allowing even larger current account deficits without adding to the debt burden. Interestingly, while the 1977-81 recovery had taken place only after the postindependence turmoil had subsided, the 1987 expansion began much before the end of the civil war, thus providing evidence of the positive effects of reforms on economic performance ahead of the postwar rebound effect.

\footnotetext{
${ }^{9}$ According to official statistics, debt service due and actually paid in 1981 and 1982 was US\$345 million and US\$390 million, respectively (Table 1): the highest annual nominal amounts ever paid by Mozambique.

${ }^{10}$ See Lopes and Sacerdoti (1991) for the details of this program and its impact on economic performance, including on poverty.
} 


\section{G. Creditor Financing and Refinancing Policies}

55. Neither western nor eastern countries ever expressed unequivocal support for Mozambique's postindependence development plans (Hall and Young, 1997). Judging with the benefit of hindsight, however, both sides of the cold war lent to Mozambique well beyond any realistic expectation of the country's ability to repay. Between 1978 and 1982, creditors lent Mozambique in excess of US $\$ 2$ billion, on relatively short terms and at market rates; by the beginning of 1983, Mozambique had run out of foreign exchange reserves and started to accumulate arrears, eventually having to request its first Paris Club debt rescheduling (Tables 1 and 3, and Annex).

56. Initially, until the early 1980 s, the supply of easy credits came primarily from the eastern bloc and from oil-exporting countries, whose joint share of Mozambique's debt reached almost 60 percent in 1984 (55 percent of which was owed to centrally planned economies) (Figure 4); later, after the government's strategic change of direction in foreign and economic policy, multilateral institutions, including particularly the World Bank and the Fund, became the main lenders. As a result, multilateral debt was representing 40 percent of total debt at the end of 1998, with Organization for Economic Cooperation and Development (OECD) countries and other bilateral creditors each accounting for about 30 percent of the total. The marked change in the pattern of international trade and financial relations is evident also from looking at the composition of imports by country of origin: the share of imports from centrally planned economies in total imports dropped from just under 20 percent on average at the beginning of the 1980 s to virtually zero at the end of the 1990 s.

57. After the first agreement with Paris Club creditors in 1984, Mozambique obtained further debt relief through five more reschedulings (including one amendment to the fifth rescheduling), a rescheduling from Organization of Petroleum Exporting Countries (OPEC) countries, and a London Club rescheduling before reaching the completion point under the original HIPC Initiative in July 1999, and the decision point under the enhanced HIPC Initiative in March 2000 (Table 3 and Annex I). ${ }^{11}$ These agreements provided Mozambique substantial cash flow relief as evidenced by the fact that debt service paid has been about 20 percent of exports of goods and services, on average, since 1983-exceeding 30 percent only in 1988 (Figure 5 and Table 1). They also helped Mozambique maintain constructive relations with all its creditors and obtain further cash flow relief from commercial creditors, suppliers, and non-Paris Club creditors. However, these rescheduling agreements did not have a significant positive impact on the stock of debt (Figure 2) because of their low overall degree

\footnotetext{
"Mozambique's debt burden and debt relief in more recent years are extensively discussed in the staff reports for the completion point under the original HIPC Initiative and the decision point under the enhanced HIPC Initiative and will not be discussed here. These reports are available on the IMF website.
} 
of concessionality. Indeed, the first two Paris Club reschedulings were at market terms (Annex and Table 3). ${ }^{12}$

58. Some debt forgiveness started to accrue to Mozambique in 1990, with the third rescheduling under Toronto terms (Figure 5 and Annex) - which provided for the cancellation of one-third of the amounts consolidated. But the overall contribution of debt forgiveness to the stabilization of the debt ratios was small: it is estimated that total debt forgiveness under traditional debt-relief mechanisms amounted to about US\$1 billion in nominal terms during 1990-98, delivered through a progressive increase of the share of cancelled debt in the amounts consolidated (Table 3 and Annex). Furthermore, the stock of debt owed to multilateral institutions, which was not subject to rescheduling under traditional debt-relief mechanisms, rose sharply during this period, even though it was serviced regularly, because of outright new borrowing.

59. A much more important contributor to the stabilization of the debt burden in the second half of the 1980s was grant financing (Figure 5), amounting to more than US\$5 billion in nominal terms, cumulatively, during 1984-98. Official grants, which had been less than 3 percent of GDP until 1982, ${ }^{13}$ picked up in 1983, reaching more than US\$500 million in 1993 - the equivalent of about 25 percent of GDP, or almost 150 percent of exports of goods and services, and approximately five times the debt service paid in that year. After 1993, grant financing declined only partially, compensated by further debt forgiveness, perhaps reflecting a perception of decreased official financing requirements. ${ }^{14}$

60. In sum, creditors' financing and refinancing policies contributed to the sharp rise, and, more recently, the fall of Mozambique's debt burden. The overall contribution, therefore, is difficult to assess. In the late 1970 s and early 1980 s, creditors lent to Mozambique excessively, paying little attention to the country's ability to repay or even to the quality of the

\footnotetext{
${ }^{12}$ See Piñon-Farah (1999) on debt relief to Mozambique under traditional rescheduling mechanisms; Daseking and Powell (1999) for a comprehensive account of debt relief under traditional rescheduling mechanisms; and IMF (1998 and 2000) for a survey of recent developments in official financing to developing countries, including the genesis and evolution of the HIPC Initiative.

${ }^{13}$ Mozambique did not receive aid from the European Community until 1982, when it signed the Lomé Convention, and it was receiving only humanitarian aid from the United States in the early 1980 s.

${ }^{14}$ Even though total financing requirements remained very large throughout the 1990s (Table 1), both the emergence of private sector financing through foreign direct investment and the expectation of much larger amounts of debt forgiveness in the context of the original HIPC Initiative launched in 1996 might have contributed to this perception.
} 
projects financed. Since the economic and financial crisis of the early 1980 s, however, they have been engaged in a close dialogue with Mozambique through successive rescheduling agreements under terms progressively more concessional, eventually leading to the HIPC Initiative. Total net financial assistance provided by the international community under the framework of traditional rescheduling mechanisms failed to stabilize Mozambique's debt burden at a sustainable level, but, together with Mozambique's own strong policy effort, it had contributed by the end of the 1990 s to a radical change in the composition of the country's foreign financing: the share of net debt-creating instruments in total foreign financing requirements fell to about 40 percent (on average) during the period 1994-98, as compared to 90 percent during 1980-84 (Figure 4).

\section{H. Conclusions and Policy Implications}

61. The facts presented on the origin and evolution of Mozambique's external debt indicate that external shocks, political factors, domestic economic policies, and creditors' financing and refinancing policies all played a role in explaining the country's debt burden. A quantification of the relative contribution of each of them separately is difficult and has not been attempted. The evidence presented, however, suggests that the civil war and the related external political factors and domestic economic policies are probably the most important contributors. The war has inflicted a very large loss of human and physical capital on the economy; nationalization and economic planning has distorted agents' incentives and behavior. Both the war and the planning experiment have disrupted productive and export capacity, increased financing requirements, and weakened property rights. Different from many other low-income countries, terms of trade shocks did not play a major role in Mozambique's external imbalance, while weather-related shocks contributed to large deficits in the food balance, which put the balance of payments under almost continuous pressure. Financial assistance made available to Mozambique under the framework of traditional debtrescheduling mechanisms provided for significant amounts of cash-flow relief but failed to bring the debt burden down to sustainable levels. Furthermore, both Mozambique and its creditors seem to have overestimated the country's ability to repay the debt, and the attempt to increase the capital stock rapidly through large investments in a short period of time may have further reduced the economic and social return of the projects financed.

62. Several lessons may be learned from Mozambique's experience:

- $\quad$ Fears of excessive dependence on revenue deriving from the export of primary commodities are perhaps misplaced. Therefore, the government might promote more actively the recovery of production and investment in traditional export sectors, and the development of new activities related to the extraction and export of natural resources. To reduce aid dependency, as well as the associated vulnerability to exogenous political developments, any medium-term poverty-reducing growth strategy must be also strongly outward oriented. 
- Weather-related natural disasters are a constant source of risk, as demonstrated by the devastating effects of the most recent floods; the ongoing reconstruction effort should aim at rebuilding public infrastructure and damaged private sector property to higher and safer standards. The government should also promote the development of a domestic insurance market enabling the private sector to share risk originating from weather-related shocks.

- More external financial resources, delivered earlier, would have been needed to stabilize Mozambique's debt burden at a sustainable level within the framework of traditional debt-relief initiatives. Nevertheless, the assistance provided to Mozambique allowed the government to carry an unsustainable debt burden over an extended period of time because the debt relief that was given was accompanied by higher grants and more-and more - concessional credits. Grant financing, in particular, allowed much larger current account deficits to accumulate than debt sustainability considerations would have warranted, thereby permitting a smoother adjustment toward external viability.

- Mozambique's financing requirements are likely to remain large in the medium term, and aid dependency can be reduced only gradually. It is thus important that the debt forgiveness under the HIPC Initiative continue to be complemented by appropriate levels of grant financing. It is also important that Mozambique make effective use of this assistance to spur growth and fight poverty.

- Thanks to Mozambique's reform efforts, which started more than a decade ago, economic growth has long since taken off, domestic macroeconomic stability and external viability have been restored, and the debt burden is being permanently alleviated by forthcoming assistance under the HIPC Initiative. However, much remains to be done to fight poverty and restore room for maneuver in policymaking. To this end, further development of an environment conducive to large inflows of foreign direct investments should be high on the government's policy agenda.

- $\quad$ Last but not least, the evidence presented strongly suggests that peace is the most important public good the government is providing to its people, and all efforts should be made to preserve it.

\section{References}

Baltazar, R. and Associates, 1999, Revisão da Iniciativa HIPC (Maputo, Mozambique: Grupo Moçambicano da Dívida).

Brooks, Ray, and others, 1998, "External Debt Histories of Ten Low-Income Developing Countries: Lessons from Their Experience," IMF Working Paper 98/72 (Washington: International Monetary Fund). 
Bruck, T., 1997, "Macroeconomic Effects of the War in Mozambique," QEH Working Paper No. 11 (Oxford: University of Oxford International Development Center).

Bruck, T., E. V K. Fitzgerald, and A. Grigsby, 2000, "Enhancing the Private Sector Contribution to Post-War Recovery in Poor Countries," QEH Working Paper No. 45 (Oxford: University of Oxford International Development Center).

Comissão Nacional do Plano (CNP), 1985, Informação Estatística: 1975-1984, (Maputo, Mozambique: Direç̧ão National de Estatística).

Daseking, Christina, and Robert Powell, 1999, "From Toronto Terms to the HIPC Initiative: A Brief History of Debt Relief for Low-Income Countries," IMF Working Paper 99/142 (Washington: International Monetary Fund).

Hall, Margaret, and Tom Young, 1997, Confronting Leviathan: Mozambique Since Independence (Athens, Ohio: Ohio University Press).

Hanlon, Joseph, 1997, Paz Sem Beneficio: Como o FMI Bloqueia a Reconstrução de Mocambique, (Maputo, Mozambique: Coleç̧ão Nosso Chão, No. 10).

IMF, 1998, Official Financing for Developing Countries, World Economic and Financial Surveys, (Washington: International Monetary Fund).

IMF, 2000, Official Financing for Developing Countries (unpublished; Washington: International Monetary Fund).

Leite, Sérgio Pereira, and others, 1998, Republic of Mozambique-Selected Issues, IMF Staff Country Report No. 98/59 (Washington: International Monetary Fund).

Lopes, Paulo S., and Emilio Sacerdoti, 1991, "Mozambique: Economic Rehabilitation and the Poor," IMF Working Paper 91/101 (Washington: International Monetary Fund).

Piñon-Farah, Marco, 1999, "Debt Relief to Mozambique Under Traditional Rescheduling Mechanisms" (unpublished; Washington: International Monetary Fund).

World Bank, 2000, Global Development Finance (Washington: World Bank). 
Box 1. Mozambique: Key Dates in the Recent History

Political Events

The war of indspendence starts in northem Mozambique.

Zimbabwe African Nationa! Lnion (Zanu) begins military operations to oust white minority government in Rhodesia from bases in Frelimo-controlled zones of Mozambiąue.

Rhodesia's inteltigence sets up rebel group in Mozambique-which witl become Renamo-to combat Frelimo and Zanu (Aprii). Portuguese revolution (April). The Lusaka Accord is negotiated (September).

Mozambique becomes independent (June)

Mozambique adheres to the UN embargo against fonner Rhodesia by clasing its borders (March).

Third National Congress of Freilmo: Frelimo converts itself into a communist politica party

The opposition party (Renarno) is formed with support from former Rhodesia.

Zimbabwean independence ends Mozambican participation in costly erabargo of Former Rhodesia. Zimbabwe withdraws support from Renamo.

South Africa takes over the support for Renamo.

Matola attack

Rail linik between Moatize and Beira disnupted.

Fourth National Congress of Frelimo

South Africa and Mozanbique sign the Nkomati Accord, pledging mutual nonaggression

The civil war intensifies: the railway Nacala-Malawi is interrupted.

Founding president Samora Machel dies in a plane crash and is succeeded by loacuim Chissano. Renamo is expelted from Malawi but intepsifies its military operations in Mozambique.

The peace negotiations start with the first meeting between govemment and opposition in Rorne, leading to a partial cease-fire in the Zimbabwean-Mozambican railway corridors. A new constitution paves the way for a multiparty democracy.

A cease-fire between Frelimo and Renamo is signed in Rome (October).

The UN peacekeeping forces arrive in Mozanbique (March)

The first free pariarnentary and presidential elections are held under UN supervision (October). First parliementary session (Decentber).

The first free locsl elections are held in 13 cities and municipalities.

The second free parliamentary and presidential elections are held (December),
1964

1972

1975 Loss of human capital due to the departure of Portuguese settlers.

1976 Cost of the embargo for Mozambique estimated at more then US\$250 million (Hall and Young, 1997).

1977 Frelimo embraces principles of planned economy. Limpopo and Incomati Rivers flooded.

1978 South Africa discontisues the practice of paying 60 percent of the salaries of Mozambican workers directly to the Bank of Mozambique in gold valued at the pre1973 official price. The Zarnbezi River flooded.

1980 First Southern African Development Cammunity (SADC) Conference in Maputo.

1981 A major drought affects the whole cougtry. Mozambique's application for entry into the CMEA trading bloc is rejected. A system of goods rationing is introduced in Maputo.

1982 A major drought affects the whole country. Mozambique applies for membership of the IMF and the World Bark.

1983 Major drought continues. Frelimo makes first steps toward embracing marke economy. Government issues first appcal for food aid as famine worsens. Rationing systern in Maputo tigktened.

1984 Floods bit the country. Cahora Bassa Hydroelectric plant stops supplying energy to South Aftica becouse of massive destruction of transmission lines (February). Mozambique joins the IMF and the World Bank (September). First Paris Club rescheduling (October)

1985 Floods hir the country. First IDA rebabilitation credit (June). OPEC debt rescheduljin (December).

1986 Severe drought. Rationing system extended to Beirg.

1987 Severe drought continues. Hyperinflation, The first JMF structural adjistment program is introduced. London Club rescheduling (May). Second Paris Club rescheduling (June)

1990 Third Paris Club rescheduling-Toronto terms. (June)

1991 A severe drought affecting the whole of Southem Africa threatens over three million Mozambicans with starvation.

1992 Severe drought continues.

1993 Fourth Paris Club rescheduling London terms-(Mareh).

1994

作

1998 Amendment to the Fifth Paris Club rescheduling (May).

1999 Mozambique reaches the completion peint under the original HIPC Initiative.

2000 Major floods. Mozanbique reaches the decision point under the enhanced HIPC Initiative.

Sources: Hanlon (1997); Bruck, Fitzgerald, and Grigsby (2000); Hall and Young (1997); and IMF staff. 
Figure 1. Mozambique: Debt Burden, 1975-98

Stock and Flows of Net External Debt

(In percent of exports of goods and services)

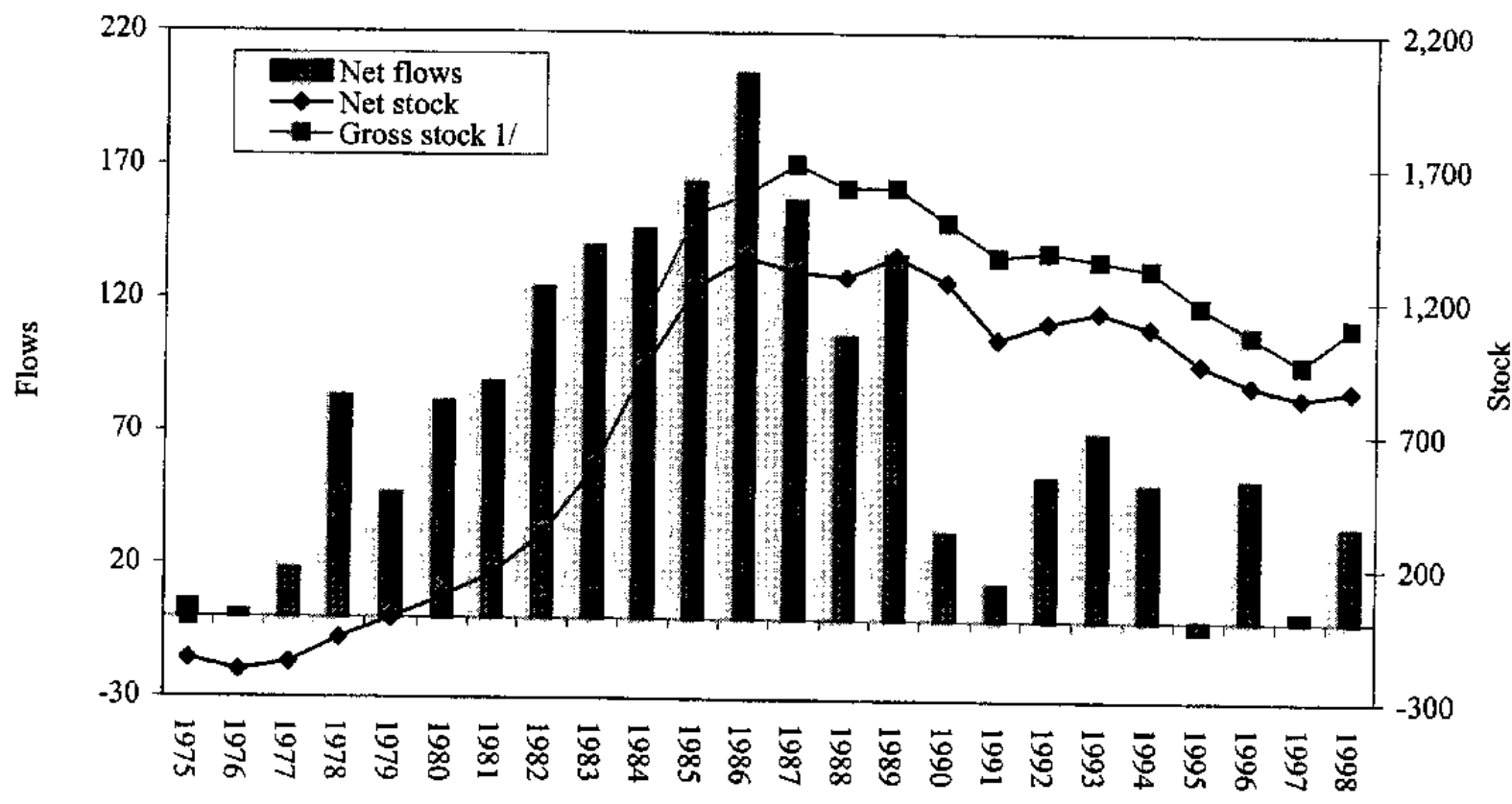

Stock and Flows of Net External Debt

(In percent of GDP)

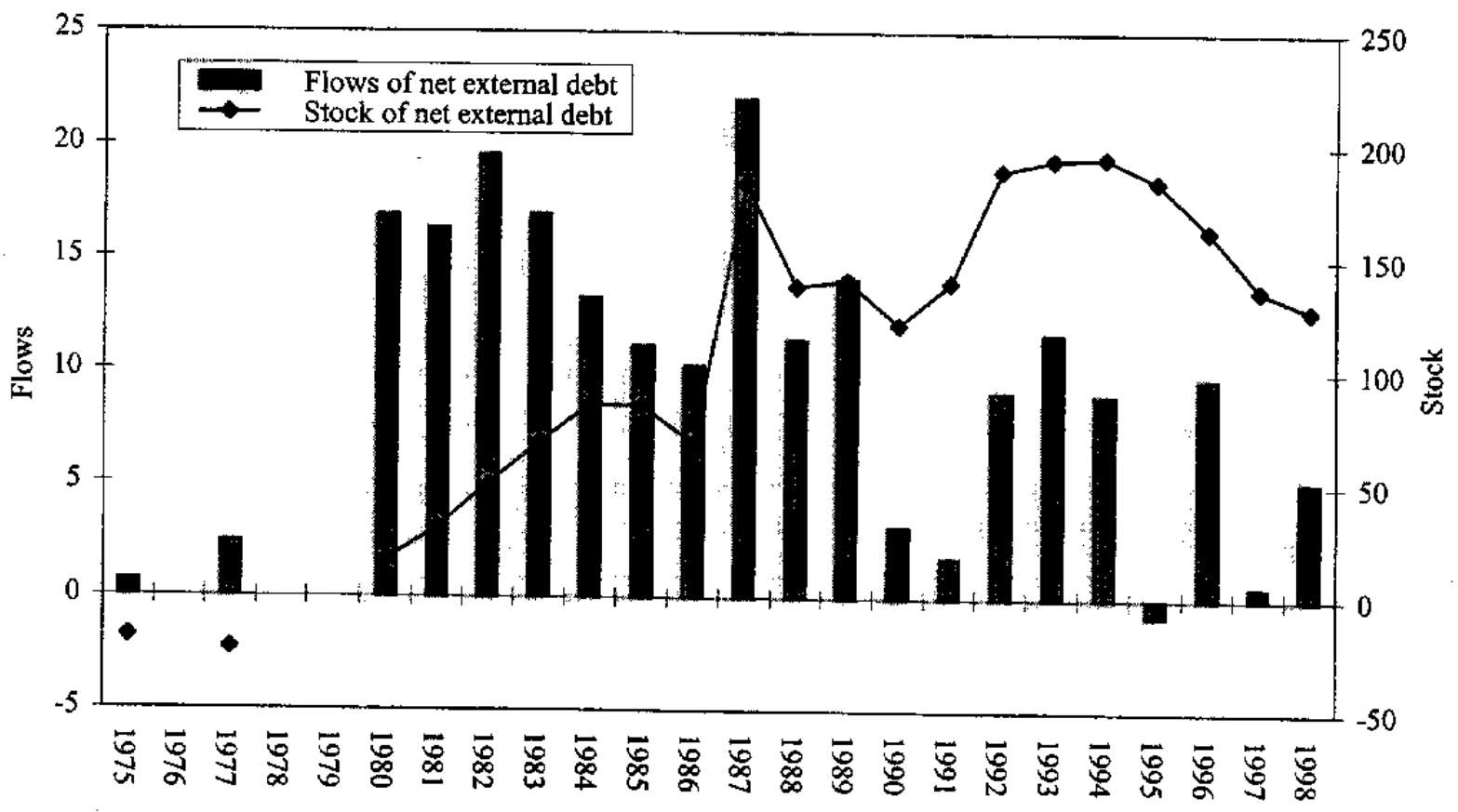

Source: Table 1.

1/ Gross public debt. 
Figure 2. Mozambique: Composition of Net Debt-Creating Flows, 1975-98

(In percent of total flow)

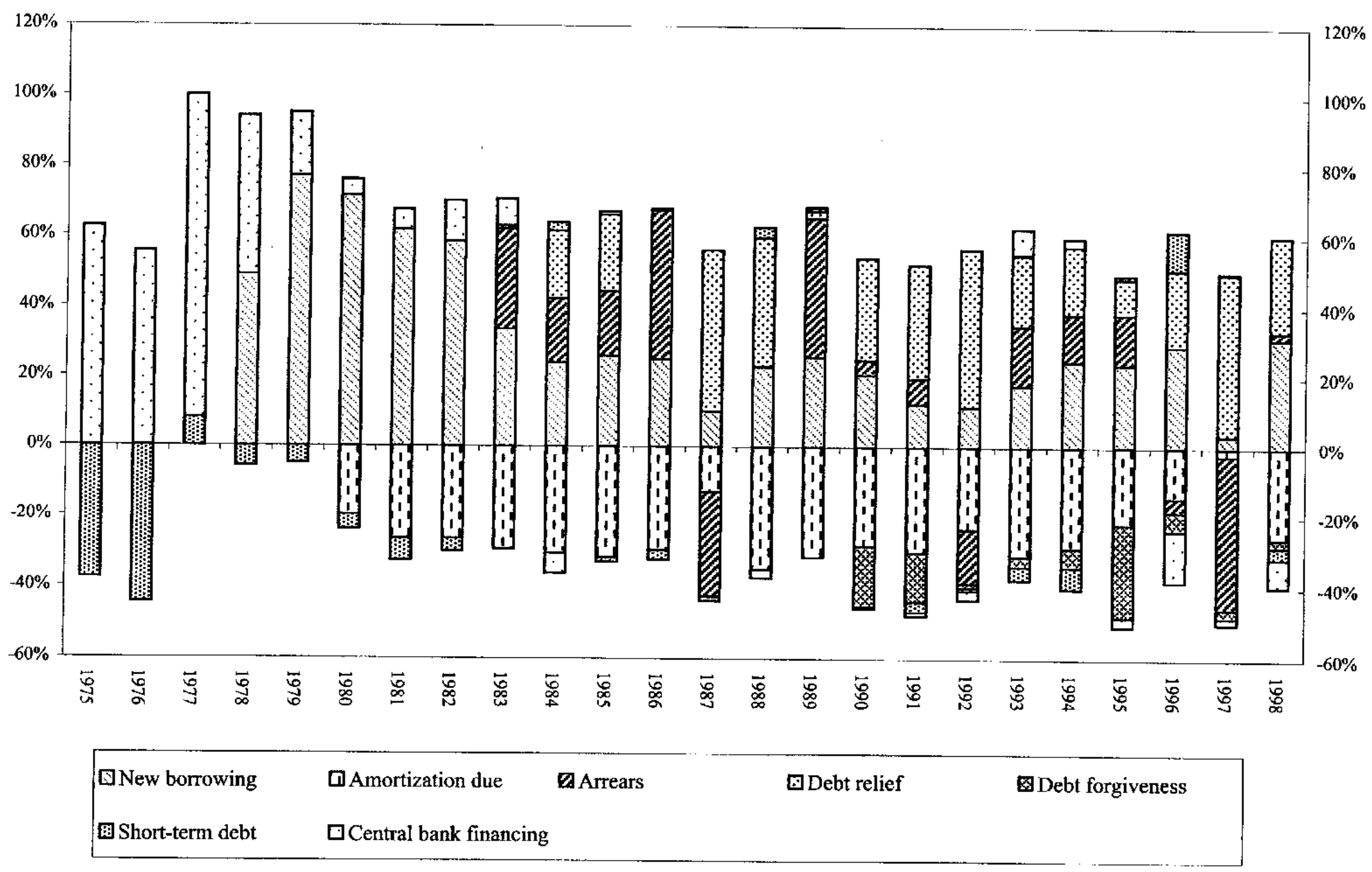

Sources: Table 1. 
Figure 3. Mozambique: Potential Explanatory Factors, 1978-98

Terms of Trade and Exports of Goods and Services

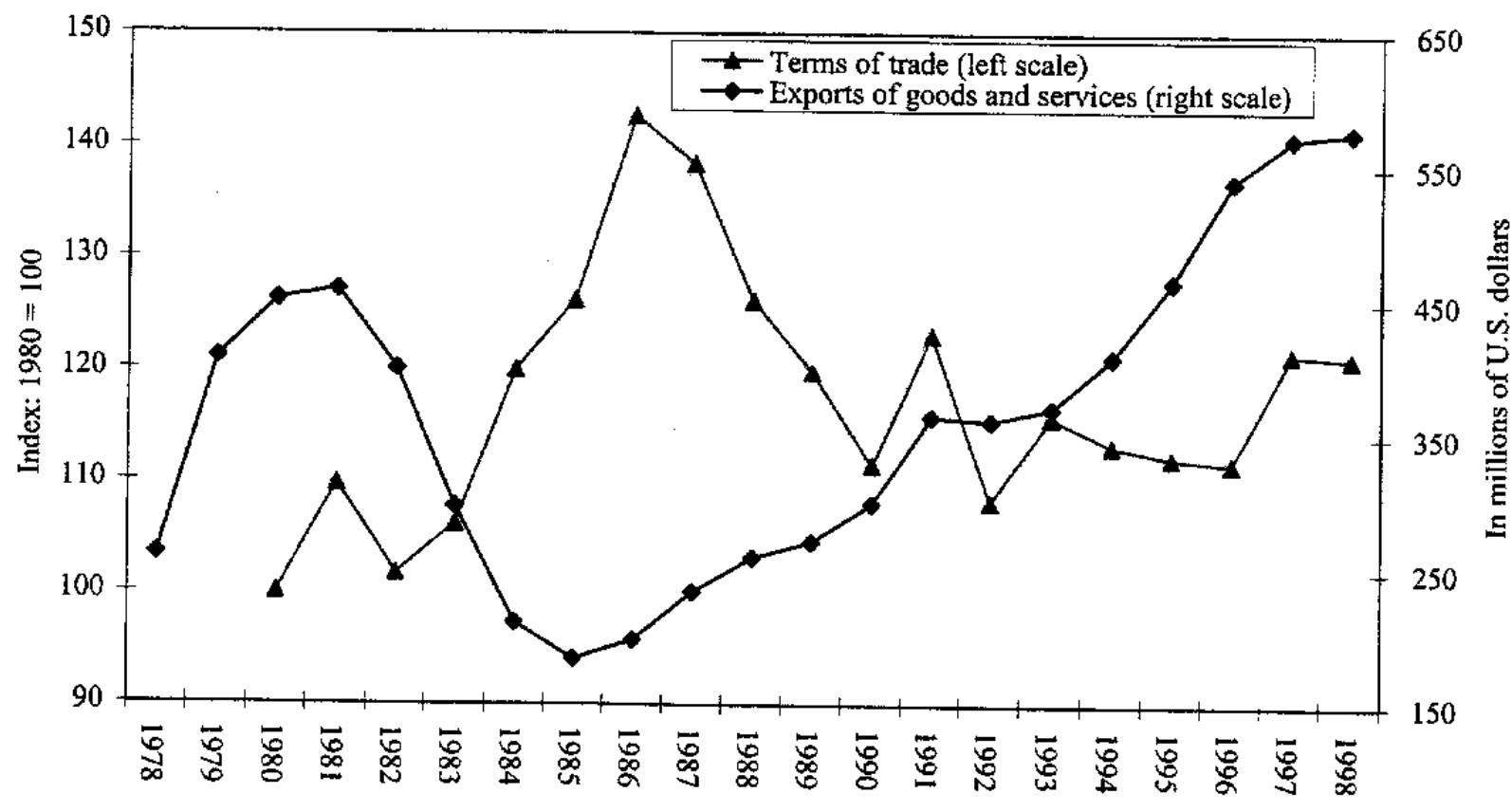

Military Expenditure

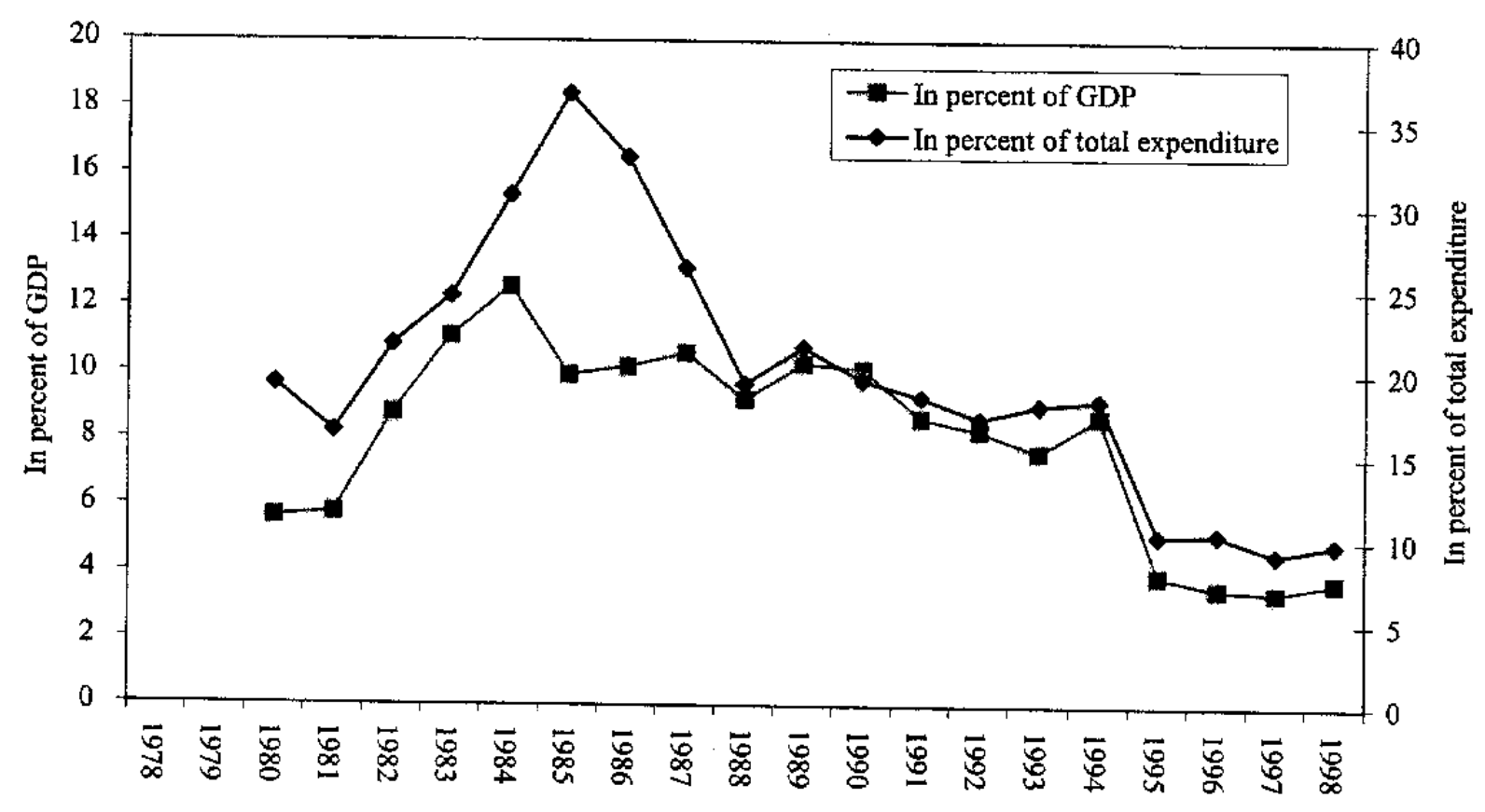

Source: Table 1; military expenditure is from Bruck, Fitzerald, and Grigsby (2000). 
Figure 4. Mozambique: Composition of Foreign Financing by Creditor and Sources

Stock of Gross Debt by Lender, 1984

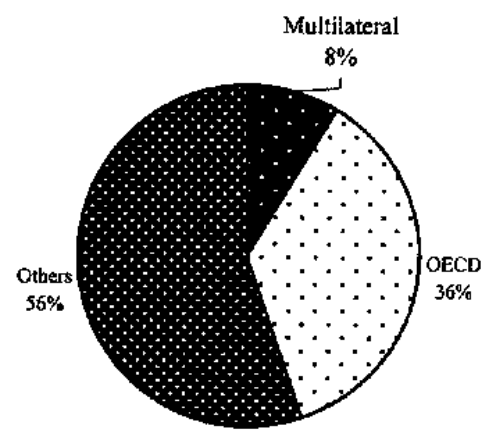

Imports by Country of Origin

(Average share: 1980-84)

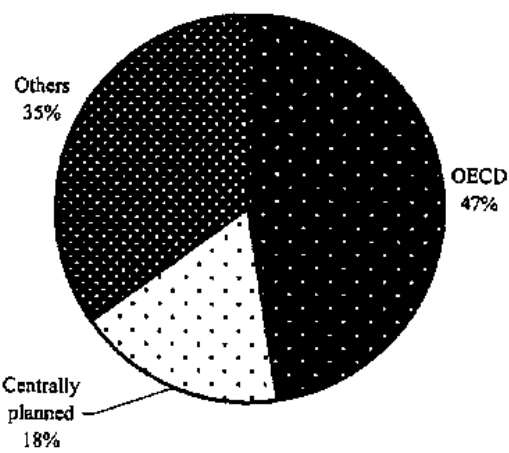

Composition of Financing

(Average share: $1980-84$ )

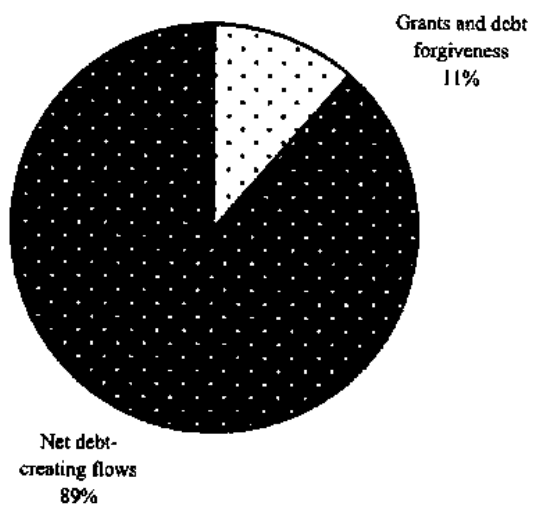

Stock of Gross Debt by Lender, 1998

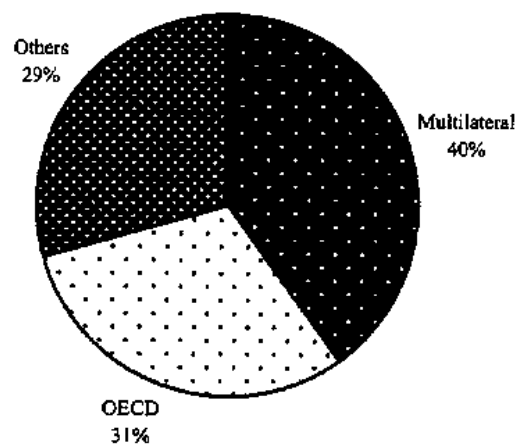

Imports by Country of Origin (Average share: 1994-98)

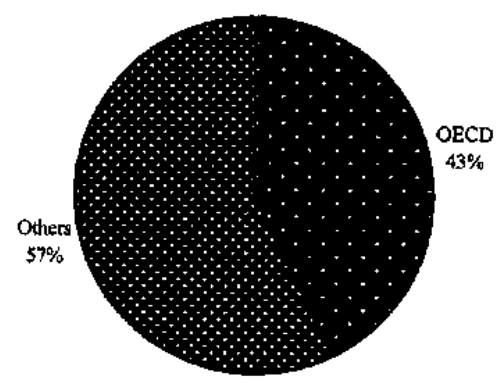

Composition of Financing

(Average share: 1994-98)

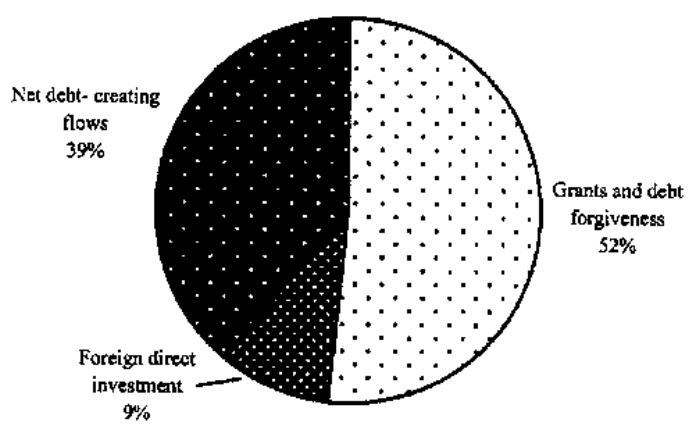

Sources: Staff estimates. 
Figure 5. Mozambique: Assistance Under Traditional Rescheduling Mechanisms, 1978-98

Grants and Debt Forgiveness

(In millions of U.S. dollars)

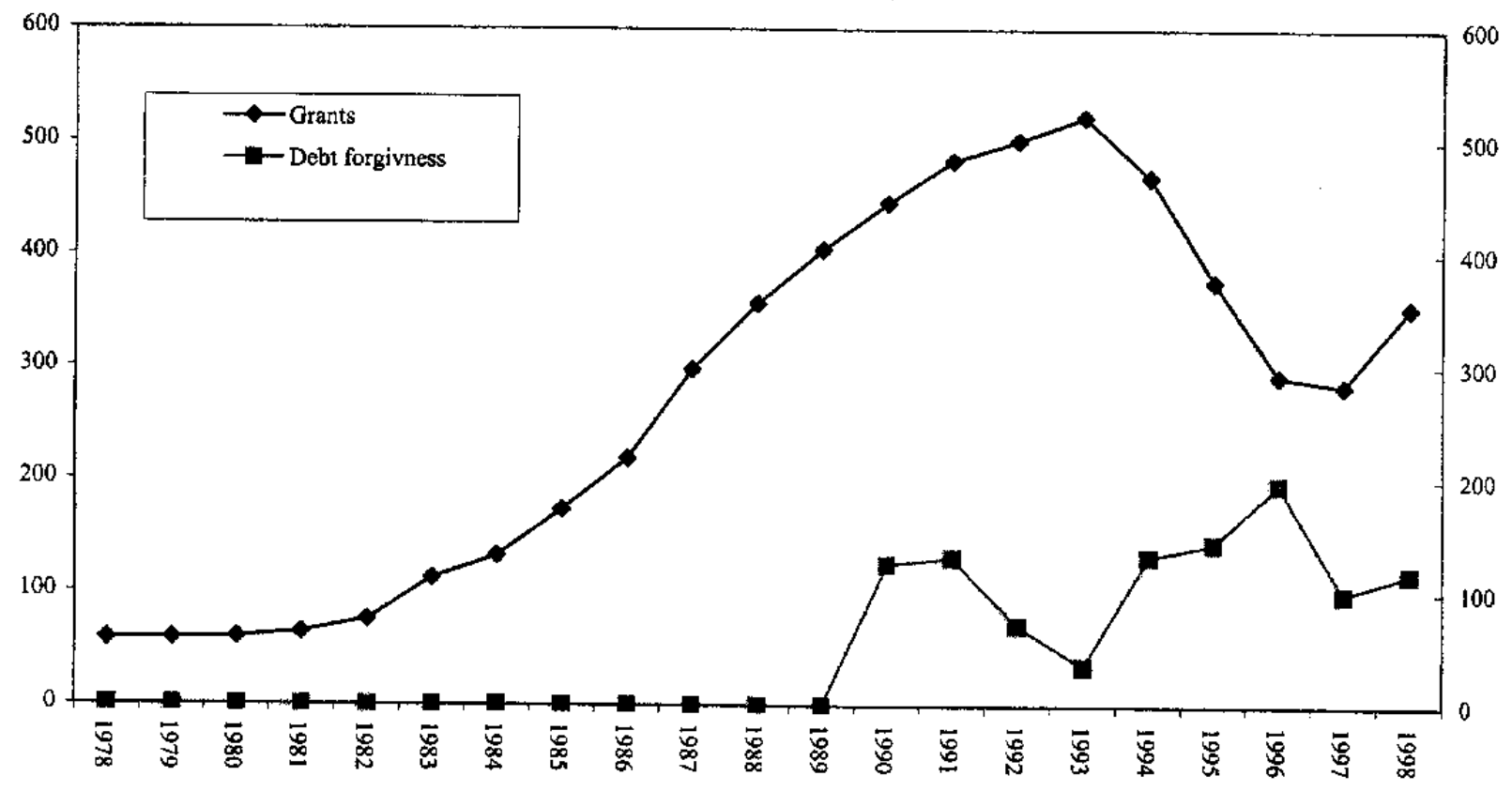

Debt Service Scheduled and Paid

(In percent of export of goods and services)

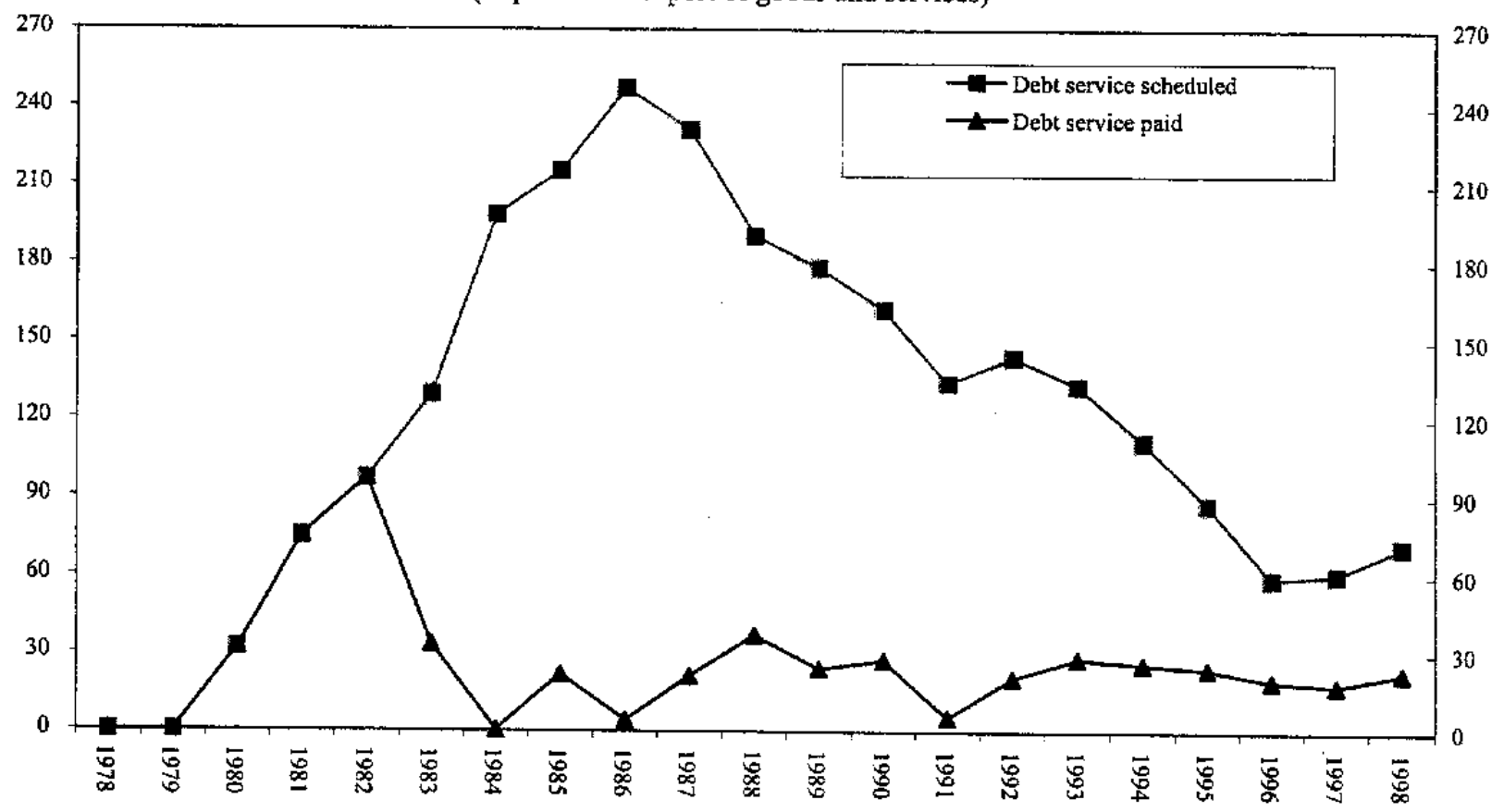

Source: Table 1. 
Table 1. Mozanbique: Balance of Payments, 1973-98

(In millions of U.S. dollars, unjess otherwise specified)

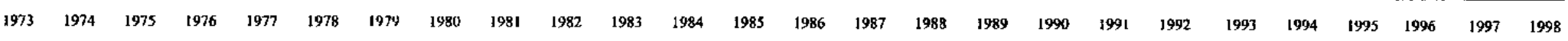

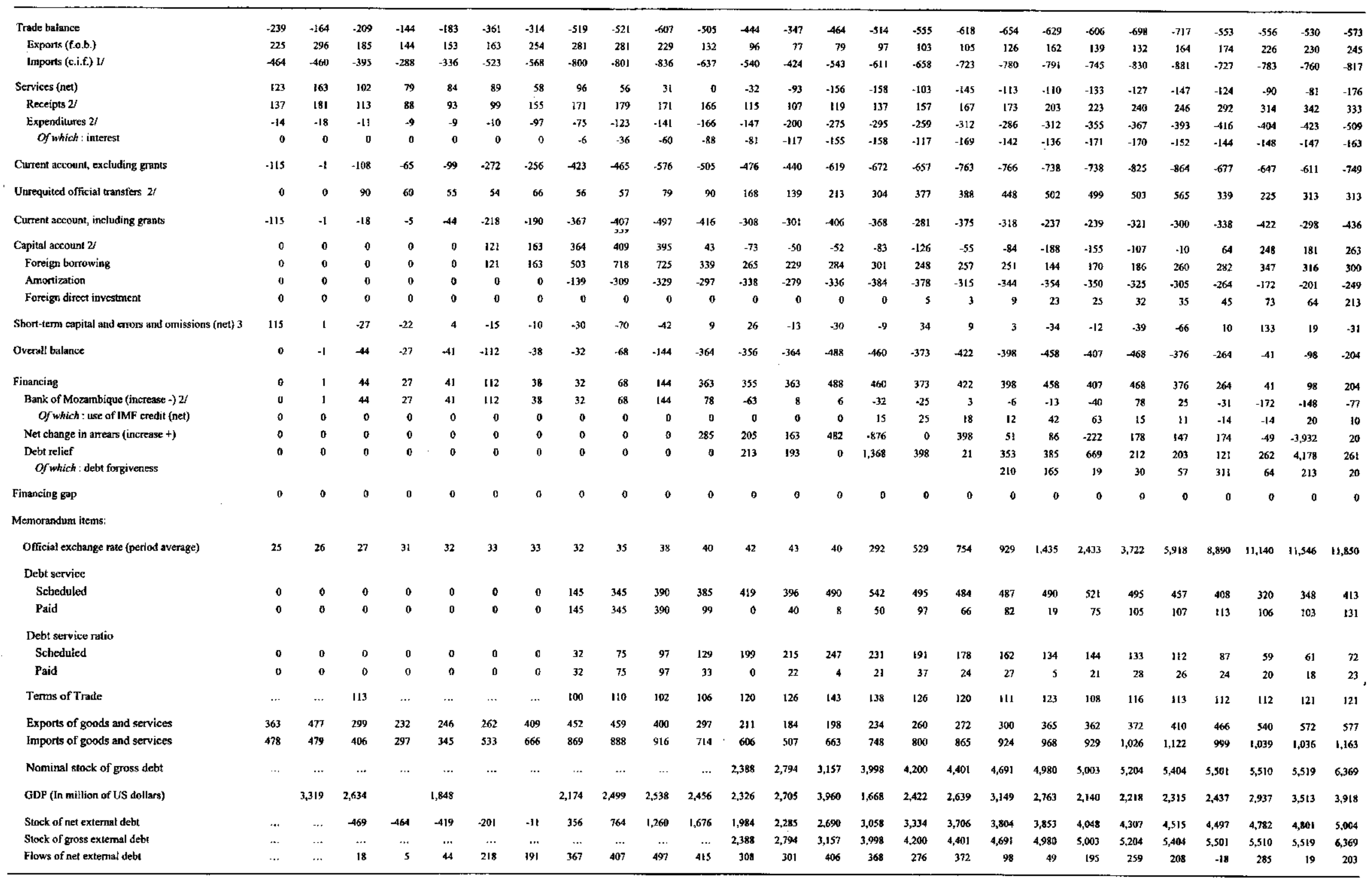

Sources: Staff estimates; CNP (1985) (for 1973-1979); and staff estimates for other years. Data on debt forgiveness are from Globai Development Finaroce of the World Banks, which arc based on the Debior Reponting System databasc.

$1 /$ Includuding privale transfers.

2/ $1973-1977$ data are estimules.

3/ Including commercial barts' net foreign assets. 
Table 2. Mozambique: Macroeconomic Performance

\begin{tabular}{lrrrrr} 
& \multicolumn{4}{c}{ Annual Averages 1/ } \\
\cline { 2 - 5 } & $1974-76$ & $1977-81$ & $1982-86$ & $1987-93$ & $1994-98$ \\
\hline GDP & \multicolumn{3}{c}{ (Annual percent changes, unless otherwise noted) } \\
Consumer prices & -20.3 & 5.6 & -5.2 & 3.3 & 8.4 \\
Current account, excluding grants (in percent of GDP) & 5.2 & 11.0 & 20.7 & 57.0 & 32.2 \\
Current account, including grants (in percent of GDP) & -2.1 & -14.5 & -19.1 & -31.3 & -24.7 \\
& -0.4 & -11.9 & -14.2 & -13.2 & -12.2 \\
\hline
\end{tabular}

Source: Table 1.

1/ Average during 1974-76 is based on 1974 and 1975; Average during 1977-81 is based on 1977, 1980, and 1981. 
Table 3. Mozambique: Evolution of Paris Club Agreements 1984-98

\begin{tabular}{|c|c|c|c|c|c|c|c|c|c|c|c|c|c|}
\hline \multirow[b]{2}{*}{$\begin{array}{l}\text { Date of Paris Club } \\
\text { Agreement }\end{array}$} & \multirow{2}{*}{\multicolumn{2}{|c|}{ Eligible Debts }} & \multirow[b]{2}{*}{$\begin{array}{l}\text { Type of } \\
\text { Agreememt }\end{array}$} & \multirow[b]{2}{*}{$\begin{array}{c}\text { Stock } \\
\text { Clause 1/ }\end{array}$} & \multicolumn{2}{|c|}{ Consolidation Period } & \multirow[b]{2}{*}{ Terms } & \multicolumn{5}{|c|}{ Coverage } & \multirow{2}{*}{$\begin{array}{l}\text { Other Debss 3/ } \\
\text { Rilateral and Multilateral } \\
\text { commercial }\end{array}$} \\
\hline & & Cutoff date & & & $\begin{array}{l}\text { Asrears } \\
\text { as of: } 2 t\end{array}$ & $\begin{array}{l}\text { Current } \\
\text { maturities }\end{array}$ & & $\begin{array}{l}\text { Original } \\
\text { maturities }\end{array}$ & $\begin{array}{l}\text { Maturi } \\
984\end{array}$ & $\frac{\text { ties from pre }}{1987}$ & $\frac{\text { evious resch }}{1990}$ & $\frac{\text { tedulings: }}{1993}$ & \\
\hline $\begin{array}{c}\text { Octoter, } 251984 \\
\text { (first rescheduling) }\end{array}$ & $\begin{array}{l}\text { Government and government- } \\
\text { guaranteed debts from } \\
\text { participating creditor coumtries, } \\
\text { with a manurity of over onc year }\end{array}$ & Febraary l, 1984 & $\begin{array}{l}\text { Nonconcessional } \\
\text { flow operation }\end{array}$ & No & Fuly 1,1984 & $\begin{array}{l}\text { July } 1,1984 \text { to } \\
\text { June } 30,1985\end{array}$ & $\begin{array}{l}\text { Market-based } \\
\text { rescheduling }\end{array}$ & Included & - & - & - & - & $\begin{array}{l}\text { Comparablity Not included } \\
\text { clause }\end{array}$ \\
\hline $\begin{array}{l}\text { June 16, } 1987 \\
\text { (second reschedulung) }\end{array}$ & $\begin{array}{l}\text { Same eligibility as } \\
\text { in previous agreement }\end{array}$ & February 1, 1984 & $\begin{array}{l}\text { Nonconcessional } \\
\text { flow operation }\end{array}$ & No & May 31, 1987 & $\begin{array}{c}\text { June 1, } 1987 \text { to } \\
\text { December 31, } 1988\end{array}$ & $\begin{array}{l}\text { Market-based } \\
\text { reschedeling }\end{array}$ & Included & Inciuded & - & - & - & $\begin{array}{l}\text { Comparability Not included } \\
\text { clause }\end{array}$ \\
\hline $\begin{array}{l}\text { June 14, } 1990 \\
\text { (Torento (erms) }\end{array}$ & $\begin{array}{l}\text { Same eligibility as } \\
\text { in previous agreetment }\end{array}$ & February 1, 1984 & $\begin{array}{l}\text { Nonconcessional } \\
\text { Row Operation }\end{array}$ & No & June 30,1990 & $\begin{array}{c}\text { July 1, } 1990 \text { to } \\
\text { October 30, 1992; } \\
\text { extended to } \\
\text { Decernber 31, 1992 }\end{array}$ & $\begin{array}{l}\text { Reduction } \\
\text { equivalent to } \\
\text { 1/3 of amounts } \\
\text { consolidated }\end{array}$ & Included & Included & Included & - & - & $\begin{array}{l}\text { Comparability Not included } \\
\text { clause }\end{array}$ \\
\hline $\begin{array}{l}\text { March 23, } 1993 \\
\text { (London terms) }\end{array}$ & $\begin{array}{l}\text { Same eligibility as } \\
\text { in previous agreentent }\end{array}$ & February 1, 1984 & $\begin{array}{l}\text { Conccssional } \\
\text { flow operation }\end{array}$ & Yes & - & $\begin{array}{c}\text { Jantary 1, } 1993 \text { to } \\
\text { December 31, } 1993 ; \\
\text { extended to } \\
\text { December 31, } 1994\end{array}$ & $\begin{array}{l}\text { Reduction } \\
\text { cquivalent to } \\
1 / 2 \text { of amovints } \\
\text { consolidated }\end{array}$ & Included & Included & Encluded & - & - & $\begin{array}{l}\text { Comparability Not included } \\
\text { clause }\end{array}$ \\
\hline $\begin{array}{l}\text { November 21, } 1996 \\
\text { (Naples terms) }\end{array}$ & $\begin{array}{l}\text { Same eligibility as } \\
\text { in previous agreement }\end{array}$ & Fcbruary I, 1984 & $\begin{array}{l}\text { Concessional } \\
\text { flow operation }\end{array}$ & Yes & October 31, 1996 & $\begin{array}{l}\text { November I, } 1996 \text { to } \\
\text { June 30, } 1999\end{array}$ & $\begin{array}{c}\text { Reduction } \\
\text { equivalent to } \\
2 / 3 \text { of amounts } \\
\text { consolididated }\end{array}$ & Included & Included & Included & Included & $\begin{array}{c}\text { Partially } \\
\text { ineluded }\end{array}$ & $\begin{array}{l}\text { Comparability Not included } \\
\text { clause }\end{array}$ \\
\hline $\begin{array}{c}\text { May 25, } 1998 \\
\text { (amendnent to 1996 } \\
\text { agreement, Lyons } \\
\text { terms) }\end{array}$ & $\begin{array}{l}\text { Same eligibility as } \\
\text { in previous agreement }\end{array}$ & February 1, 1984 & $\begin{array}{l}\text { Concessional } \\
\text { flow operation }\end{array}$ & Yes & - & $\begin{array}{l}\text { July 1, } 1997 \text { 10 } \\
\text { June 30, } 1999\end{array}$ & $\begin{array}{l}\text { Reduction } \\
\text { equivalent to } \\
4 / 5 \text { of amounts } \\
\text { consolidated }\end{array}$ & Included & Included & Included & Included & Included & $\begin{array}{l}\text { Comparability Not included } \\
\text { clause }\end{array}$ \\
\hline
\end{tabular}

1/ Since 1993, Paris Club agrecments have inchided a clause that slates that creditors would be willing to meet in the future to consider the issux of the stock of debt.

$2 /$ Includes only presectuoff-debt arrears.

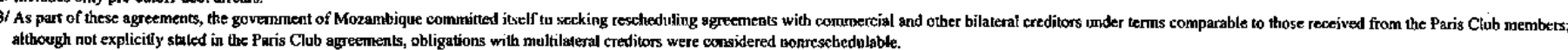




\section{Debt Relief Under Traditional Rescheduling Mechanisms ${ }^{15}$}

63. In broad terms, the evolution of Mozambique's five debt-rescheduling agreements, and one amendment, with Paris Club member countries can be characterized by its steady progression from a lower to a higher degree of concessionality. While the first and second rescheduling (1984 and 1987) were not concessional, the third rescheduling (1990) embodied a one-third reduction ("Toronto" terms) of the consolidated amounts in net present value terms, the fourth rescheduling was based on a 50 percent reduction (Enhanced Toronto or "London" terms) and the fifth (1996) and last debt agreement incorporated a 67 percent reduction ("Naples" terms). All these agreements were also based on some common principles.

64. The rescheduling applied only to government and government-guaranteed loans from Paris Club member countries, with a maturity of one year or longer, and all the agreements maintained the cutoff date of February 1, 1984. This meant that only loans contracted before February 1984 were subject to rescheduling, while loans obtained after such date were considered nonreschedulable. In addition, a standard "comparability" clause was included in all agreements stipulating that the debtor country would try to secure rescheduling agreements with non-Paris Club creditors on terms comparable or more concessional than those granted by the Paris Club. While other bilateral and commercial creditors were supposed to be covered by this clause of comparability, debt service payments to multilateral institutions were considered as "nonreschedulable." All agreements secured by Mozambique - and indeed by almost all other countries until recently - were "flow" rescheduling, as opposed to "stock" reschedulings. ${ }^{16}$ To facilitate the implementation of the agreements, Mozambique was also required to open a special account with one of the central banks of participant creditors (an account was opened at the Bank of France) and to make deposits according to a predetermined schedule. The government of Mozambique would have drawn from this account to meet its obligations resulting from these agreements, once the specific bilateral agreements were finalized with each creditor.

65. 1984 agreement (first rescheduling). Although corrective economic policies were not formalized in an IMF program, as the country joined the IMF only on September 24, 1984, the government of Mozambique agreed to meet a set of targets, as contained in its

${ }^{15}$ This annex, as well as Table 3, was prepared by Marco Piñon-Farah.

${ }^{16}$ Under a flow operation, eligible debt-service arrears and payments falling due during a given time period, known as "consolidation" period, are rescheduled (and discounted, if applicable), while the repayments schedule for the remaining of the debt stock (i.e., generally maturities after the end of the consolidation period) remains unchanged. See IMF (1998 and 2000) for more details on traditional debt-relief mechanisms as well as a contrast to the HIPC Initiative and a glossary of terms used. 
Program of Economic Action. Moreover, future agreements were made conditional, among other things, on entering into an agreement with the IMF. This first agreement consisted of a nonconcessional flow rescheduling, covering arrears as of July 1, 1984 and current maturities due from July 1, 1984 to June 30, 1985 (consolidation period). Of the debt amounts rescheduled (i.e., consolidated), 95 percent were be repaid over $11 \frac{1}{2}$ years, with a grace period of 6 years, while the remaining 5 percent were to be repaid over 6 years with no grace period. Interest payments were to be agreed based on an appropriate market rate. Creditor countries agreed to consider an extension of the consolidation period to June 30, 1986, provided that Mozambique complied with the terms of this agreement, reached comparable agreements with banks and other creditors, implemented its economic program and met its targets, and entered into a first tranche arrangement with the IMF.

66. 1987 agreement (second rescheduling). The economic program presented by the authorities was supported by the first annual arrangement under the Structural Adjustment Facility (SAF) and the medium-term framework presented in the policy framework paper (PFP) for 1987-90, approved by the IMF Executive Board on June 7, 1987. The agreed consolidation period covered arrears as of May 31, 1987 and current obligations due from June 1, 1987 through December 31, 1988. Mozambique committed itself to paying all arrears resulting from noneligible debts (i.e., nonreschedulable) not later than December 31, 1987. The Paris Club agreed to consider future rescheduling at the end of the consolidation period, provided that Mozambique continued to have an arrangement under the SAF (or another arrangement involving upper tranche conditionality). All rescheduled arrears were to be repaid over a period of 21 years, with a grace period of 11 years. Repayments of current amounts due were to be made over $191 / 2$ years, including a grace period of 10 years. Interest payments were to be determined on the basis of appropriate market interest rates.

67. 1990 agreement (Toronto terms). The economic program presented by the authorities was supported by the first annual arrangement under the three-year Enhanced Structural Facility (ESAF) program approved by the IMF Executive Board on June 1, 1990. The agreed consolidation period covered arrears as of June 30,1990 and current obligations due from July 1, 1990 through October 30, 1991, and, provided that an ESAF arrangement continued to be in place, from November 1, 1991 through December 31, 1992. Repayments of principal and interest resulting from the 1984 and 1987 rescheduling agreements were also included among the eligible debts. Mozambique committed itself to paying all arrears resulting from noneligible debts (i.e., nonreschedulable) not later than September 30, 1990 and continued to be required to make regular deposits in the special account held at the Bank of France on the basis of an agreed schedule. Under this agreement, three options were given to creditors to be applied to non-official development assistance (ODA) debt, two of which were - for the first time - concessional (Toronto terms): (i) cancellation of one-third of the amounts consolidated, repayment of the remaining two-thirds over a period of 15 years, with a grace period of 5 years, and interest payments based on an appropriate market rate; (ii) rescheduling of amounts consolidated over 25 years, with a grace period of 14 years, and interest payments based on an appropriate market interest rate (nonconcessional option); and (iii) rescheduling of the amounts consolidated over 25 years, with a grace period of 10 years, 
and interest payments based on an appropriate market interest rate reduced by 3.5 percentage points, or 50 percent, if lower than 3.5 percentage points. ODA debt was rescheduled over 25 years, with a grace period of 14 years and interest payments based on concessional ODA interest rates.

68. 1993 agreement (London terms). The economic program presented by the authorities was supported by the third annual arrangement under the ESAF, as approved by the IMF Executive Board on December 2, 1992. Compared with the previous agreement, the options offered to creditors increased the degree of reduction of the debt-service amounts consolidated from 33 percent (Toronto terms) to 50 percent (enhanced Toronto or London terms). As in the previous agreement, a nonconcessional option was retained. The agreement contained, for the first time, a clause indicating the creditors' willingness to meet to consider a reduction in the stock of debt in the future, as opposed to debt flows, provided that the country maintained an agreement with the IMF in place. The agreed consolidation period covered obligations due from January 1, 1993 through December 31, 1993 and, provided that an appropriate arrangement with the IMF continued to be in place, throughout 1994.

Repayments of principal and interest resulting from the 1984, 1987, and 1990 rescheduling agreements were also included among the eligible debts. Three options were given to creditors applying to maturities not resulting from the 1990 rescheduling or from ODA obligations: (i) cancellation of one-half of the amounts consolidated and repayment of the remaining one-half under market-determined terms and conditions; (ii) rescheduling of 100 percent of the amounts consolidated, with payments based on an appropriate market interest rate reduced so as to ensure a 50 percent debt reduction, in net present value terms; and (iii) rescheduling of 100 percent of the amounts consolidated under market-determined terms and conditions (nonconcessional option). Obligations resulting from the 1990 concessional debt rescheduling were to be rescheduled over 10-year period, with a grace period of $61 / 2$ years, and with commercial interest rates to be determined on a bilateral basis. ODA debt was rescheduled under terms to be determined bilaterally between Mozambique and each of its creditors as long as the terms and interest rates applied to the rescheduled debt were as favorable as the original terms of these debts.

69. 1996 agreement (Naples terms). The economic program presented by the authorities was supported by the first annual arrangement under a second three-year ESAF arrangement, as approved by the IMF Executive Board on June 21, 1996. This agreement dropped the nonconcessional rescheduling option that was still available to creditors during the previous reschedulings and increased the degree of reduction of the consolidated amounts from 50 percent to 67 percent. It also contained a clause indicating that creditors were willing to meet to consider a reduction in the stock of debt by June 30,1999, provided that the country maintained an appropriate arrangement with the IMF in place. The agreed consolidation period covered arrears as of October 31, 1996 and obligations due from November 1, 1996 through June 30, 1999. Repayments of principal and interest resulting from the 1984, 1987, and 1990 rescheduling agreements were also included among the eligible debts. Only a portion of the repayments of principal and interest from the 1993 were included in this rescheduling. Mozambique agreed to pay all nonreschedulable arrears as at November 11, 1996 not later 
than March 31, 1997, but was no longer required to make regular deposits into a special account during the period while pre-bilateral agreements were to be negotiated. Two nonODA options were given to creditors. The first option included the following: (i) cancellation of 67 percent maturities from non-previously rescheduled debt or resulting from previous nonconcessional rescheduling agreements; (ii) cancellation of 50 percent of maturities resulting from the 1990 rescheduling (Toronto terms) agreement, which had previously discounted the original maturities by 33 percent; and (iii) cancellation of 34 percent of maturities resulting from the 1993 rescheduling (London terms) agreement which had previously discounted the original maturities by 50 percent. In each (i), (ii), and (iii), the remaining amounts ( 33 percent, 50 percent and 66 percent), were to be repaid on the basis of an agreed repayment schedule and an appropriate market-determined interest rate. The second option for non-ODA debt included the rescheduling of 100 percent of amounts consolidated under reduced interest rates and repayment schedules so as to achieve (i) a 67 percent reduction in net present value terms, in the case of debts not previously rescheduled or rescheduled under nonconcessional terms; (ii) a 50 percent reduction in net present value terms, in the case of debts resulting from the 1993 rescheduling, which discounted the original maturities by 33 percent; and (iii) a 34 percent reduction in net present value terms, in the case of debts resulting from the 1996 rescheduling, which discounted the original maturities by 50 percent. ODA maturities were to be rescheduled under conditions and terms that were at least as favorable as those of the original debt.

70. 1998 amendment to 1996 agreement (Lyons terms). Representatives of the participating creditors met on May 25, 1998 and agreed to modify the debt-rescheduling agreement of November 21, 1996. Arrears as of October 31, 1996 and maturities that had fallen due during November 1, 1996 through June 30, 1997 remained rescheduled under the terms of the 1996 agreement. The main revision to the previously agreed rescheduling was to increase the degree of concessionality by canceling 80 percent, as opposed to the original 67 percent, of the maturities falling due during July 1, 1997 through June 30, 1999. This amendment also increased the coverage of the rescheduling by including in the consolidated amount maturities resulting from the 1993 agreement that had not been covered under the 1993 agreement. In order to increase the amount of debt reduction in net present value terms, the two non-ODA options given to creditors in 1996 were modified as follows. The revised first option included the following: (i) cancellation of 80 percent maturities from not previously rescheduled debt or resulting from previous nonconcessional rescheduling agreements; (ii) cancellation of 70 percent of maturities resulting from the 1990 rescheduling (Toronto terms) agreement, which had previously discounted the original maturities by 33 percent; and (iii) cancellation of 60 percent of maturities resulting from the 1993 rescheduling (London terms) agreement, which had previously discounted the original maturities by 50 percent. In each of (i), (ii), and (iii), the remaining amounts (20 percent, 30 percent, and 40 percent), were to be repaid on the basis of an agreed repayment schedule and an appropriate market-determined interest rate. The revised second option for non-ODA debt included the rescheduling of 100 percent of amounts consolidated under reduced interest rates and repayment schedules so as to achieve (i) an 80 percent reduction in net present value terms, in the case of debts not previously rescheduled or rescheduled under nonconcessional terms; (ii) 
a 70 percent reduction in net present value terms, in the case of debts resulting from the 1993 rescheduling, which discounted the original maturities by 33 percent; and (iii) a 60 percent reduction in net present value terms, in the case of debts resulting from the 1996 rescheduling, which discounted the original maturities by 50 percent. ODA maturities were to be rescheduled under conditions and terms that were at least as favorable as those of the original debt. 


\section{EQUILIBRIUM EXChaNGE RATE AND ITS DETERMINANTS ${ }^{17}$}

\section{A. Introduction}

71. In the late 1980s, Mozambique embarked on an economic program whose main goal was to create conditions for a broad-based, export-oriented economic growth. In this context, structural reforms led to the deregulation of most goods and services markets and a substantial liberalization of the trade regime. Price controls were eliminated, wages became the subject of tripartite negotiations, and the exchange rate system was substantially modified, becoming market determined in mid-1993. These events had a significant impact on the external competitiveness of the country and, consequently, on its economic growth.

72. This chapter studies the behavior of the real effective exchange rate through an analysis of the determinants of its equilibrium and the determination of its degree of misalignment over the period December 1993-April 2000. Following the methodology used by Alberola and others (1999), the analysis is carried out using a theoretical framework that encompasses the Balassa-Samuelson hypothesis and the "balance of payments approach" for the determination of the real exchange rate. Empirically, in a cointegration framework, an unobserved components analysis that identifies a time-varying equilibrium real exchange rate is applied. In contrast to Alberola and others (1999), our analysis is based on a monthly frequency, making the exercise more meaningful from an operational and monitoring point of view. The section is organized as follows: Subsection B provides some background on the exchange regime and exchange rate behavior in Mozambique during the last 15 years; Subsection C introduces the theoretical framework and the empirical model; Subsection D presents the data and the results; and Subsection E concludes.

\section{B. Background}

73. In 1986, the metical was grossly overvalued, and the exchange rate against the U.S. dollar in the parallel market was nearly 40 times the official rate. In 1987, the government launched an Economic Rehabilitation Program, which involved a fundamental shift to marketbased economic policies and structural reforms. In the context of these policies, exchange rates became market determined in mid-1993. The adjustment toward market rates proceeded in steps. In January 1987, the metical was sharply devalued from Mt 39 per U.S. dollar to Mt 202 per U.S. dollar, and the exchange rate peg was changed from a basket of six currencies to solely the U.S. dollar. Devaluations continued at irregular intervals until April 1989, when a system of monthly devaluations was instituted. In December 1989, the exchange rate peg was changed again to a basket of ten trading partners' currencies. In October 1990, a market for foreign exchange was introduced where commercial banks were authorized to transact with the public. After another substantial devaluation in mid-1991, foreign exchange transactions

${ }^{17}$ This section was prepared by Stefania Fabrizio. 
began to be increasingly shifted to this market. In April 1992, the official central bank rate and the market rate vis-à-vis the public were unified, but a special (more appreciated) rate for tied aid was introduced. In June 1993, this special rate was abolished.

74. After 1995, the banking system was partially privatized, exchange bureaus were legalized, and, more generally, measures were taken to liberalize the current account of the balance of payments. These developments helped create the basis for the emergence of a relatively well-functioning retail foreign exchange market, and, as a result, the spread between the exchange rate applied by commercial banks (market rate) and that applied by exchange bureaus (parallel rate) narrowed to less than 2 percent in early 1997 from 5 percent in December 1996.

75. During 1997-98, the metical depreciated vis-à-vis the U.S. dollar by slightly more than 2 percent a year; meanwhile, currencies of important trading partners such as South Africa were going through much sharper depreciations vis-à-vis the U.S. dollar, thereby inducing an appreciation of the metical in real effective terms even though inflation in Mozambique was sharply declining. These developments induced concerns at the time that the central bank was still managing the exchange rate with possible negative effects on external competitiveness (see Leite and others (1998)).

76. At the beginning of 2000 , the metical depreciated substantially vis-à-vis the U.S. dollar, and a significant spread between the market and parallel rates temporarily reappeared, peaking at near 10 percent in March 2000 in the wake of the floods that affected the country at the beginning of the year.

\section{Theoretical Framework and Empirical Model}

77. The concept of an equilibrium exchange rate has been addressed in the literature with different approaches, starting from the popular concept of purchasing power parity (PPP). This theory maintains that changes in nominal effective exchange rates must compensate for the inflation differential between the country and its trading partners, thus implying that the equilibrium exchange rate is constant. Although this view is appealing for its simplicity, several factors may produce long-run deviation between the actual exchange rate and its PPP equilibrium. Based on the Samuelson-Balassa hypothesis, a systematic divergence between the nominal and the real exchange rate appears when economies producing tradable and nontradable goods are considered. This hypothesis depends on the assumptions that tradable goods determine the nominal exchange rate between two countries; that both countries produce tradable and nontradable goods; that wages equalize between sectors but not between countries; and that more developed countries enjoy higher productivity than less developed countries in the tradable sector. Another factor that leads to deviation from the PPP is the lack of perfect substitution between tradable goods in two different countries.

78. This vision opened the door to another line of research on the determination of the exchange rate-one that emphasizes the underlying net foreign assets position of a country. 
The modern "assets" view of exchange rate determination treats the exchange rate as the price of an asset. The exchange rate must be consistent with a balance of payments position in which any current account imbalance is compensated by a sustainable flow of international capital (Mussa, 1984; and Frenkel and Mussa, 1985).

79. Our analysis is based on a theoretical framework that encompasses the tradablenontradable theory with the balance of payments approach. We consider that there are two countries in the world, each producing a tradable good $(T)$ and a nontradable good $(N)$. The real effective exchange rate $(q)$ in logarithmic terms can be defined as

$$
q=s+p-p^{*}
$$

where $p$ and $p^{*}$ are the domestic and the foreign consumer price indices (CPI), respectively, and $s$ is the nominal exchange rate. For each country, the CPI, which is formed by prices of domestic and foreign tradable goods and nontradable goods, can be expressed as follows:

$$
\begin{aligned}
& p=\left(1-\alpha_{T}-\alpha_{N}\right) p_{T}+\alpha_{N} p_{N}+\alpha_{T}\left(p_{T}^{*}-s\right) \\
& p^{*}=\left(1-\alpha_{T}^{*}-\alpha_{N}^{*}\right) p_{T}^{*}+\alpha_{N}^{*} p_{N}^{*}+\alpha_{T}^{*}\left(p_{T}-s\right)
\end{aligned}
$$

where the $\alpha$ 's determine the share of each good in the consumer price index. Substituting these expressions into (1), we obtain

$$
q=\left(1-\alpha_{T}-\alpha_{T}^{*}\right)\left(p_{T}+s-p_{T}^{*}\right)+\alpha_{N}\left[\left(p_{N}-p_{T}\right)-\left(p_{N}^{*}-p_{T}^{*}\right)\right],
$$

where the weights of nontradable goods for the two countries are assumed to be the same and tradable goods of the two countries are not perfect substitutes. The latter expression indicates that the exchange rate is determined by two different components: the evolution of the prices of domestic tradable goods relative to prices of foreign tradable goods, $q_{x}=\left(p_{T}+s-p_{T}^{*}\right)$, which reflects the external dimension of the economy; and the behavior of nontradable goods relative to tradable goods across countries, $q_{I}=\left[\left(p_{N}-p_{T}\right)-\left(p_{N}^{*}-p_{T}^{*}\right)\right]$, which relates to the internal dimension of the economy. Thus, the equilibrium exchange rate $(\bar{q})$ implies both external and internal equilibrium.

80. The external equilibrium. The external balance clears the tradable goods market and is characterized by the achievement of a desired stock of net foreign assets. The evolution of the current account balance, which determines adjustments to the equilibrium, leads to an accumulation of net foreign assets. The current account balance ( $c a$ ) is defined as the trade balance $(x)$ plus the net income received or paid by residents $\left(r^{*}\right)$ on foreign asset holdings (nfa):

$$
c a=x+r^{*} n f a,
$$


expressed in real terms. The trade balance depends on the evolution of the external real exchange rate, ${ }^{18}$ namely, $x=-\gamma q_{x}$, and the current account adjusts to the difference between the current and the desired level of net foreign assets (Mussa, 1984), so that a current account surplus would reflect a net foreign assets position below the desired level:

$$
c a=\eta(\overline{n f a}-n f a) \text {. }
$$

In the long run, $\overline{n f a}=n f a$, and the equilibrium external exchange rate can be defined as follows:

$$
\overline{q_{x}}=\left(r^{*} / \gamma\right) \overline{n f a}
$$

where the bars over the variables indicate long-run equilibrium values.

81. The internal equilibrium. The evolution of the internal real exchange is determined by the differences in behavior of sectoral relative prices between countries, which, in turn, are related to the evolution of sector productivities. Based on the productivity hypothesis (Balassa-Samuelson hypothesis), it can be shown that

$$
\bar{p}_{N}-\bar{p}_{T}=\mu+\left(y_{T}-y_{N}\right)
$$

where the $y$ 's are the average sectoral productivities (see Obstfeld and Rogoff (1996), among others, for an illustration of the Balassa-Samuelson hypothesis). Neglecting constant terms, it follows that the equilibrium internal exchange rate can be expressed as follows:

$$
\bar{q}_{I}=\alpha_{N}\left[\left(\bar{p}_{N}-\bar{p}_{T}\right)-\left(\bar{p}_{N}^{*}-\bar{p}_{T}^{*}\right)\right]=\alpha_{N}\left[\left(y_{T}-y_{N}\right)-\left(y_{T}^{*}-y_{N}^{*}\right)\right]=\alpha_{N} \bar{n}
$$

82. The empirical model. The theoretical model has identified two main determinants of the real exchange rate $(q)$ in the long run: the stock of net foreign assets ( $n f a)$ and the relative sectoral prices between countries $(n)$. Therefore, the empirical model to estimate would be the following:

$$
q_{t}=\beta_{0}+\beta_{1} n f a_{i}+\beta_{2} n_{t}+u_{t}
$$

83. Since our main objective is to compute the equilibrium exchange rate as a function of its fundamentals, we have first to establish the existence of a long-run relationship among the variables, and then to compute the equilibrium levels of the determinants $n f a$ and $n$. In order

${ }^{18}$ An appreciation of the external exchange rate $\left(q_{x}>0\right)$ will worsens the competitiveness of the domestic products and, consequently, the trade balance, when the Marshall-Lerner condition holds. 
to determine the existence of a long-run relationship among variables (i.e., to test for cointegration), we use the Johansen procedure for cointegration. To establish the equilibrium level of the real exchange rate, we assume that $q_{t}$ fluctuates around its long-term value but is not permanently at that value. Moreover, in order to derive the equilibrium exchange rate, we also allow for the possibility that $n f a_{t}$ and $n_{t}$ deviate from their long-run values. From an empirical point of view, the three variables in the system are decomposed into transitory and permanent components, with the latter capturing the equilibrium of the system. Bearing in mind that a unique decomposition between permanent and transitory components does not exist (see, among others, Maravall (1993) and Quah (1992)), we consider the decomposition suggested by Gonzalo and Granger (1995), based on the assumption that shocks to the transitory component (i.e., our estimate of the misalignment) do not affect the permanent component (i.e., our estimate of the equilibrium).

\section{Data and Empirical Results}

84. The analysis has been conducted using monthly data of (i) the real effective exchange rate, (ii) the net foreign assets of the banking system, normalized by broad money in order to adjust for the size of the country, ${ }^{19,}{ }^{20}$ (iii) and an index of relative sectoral prices for the period December 1993-April 2000 (Figure 6). The latter has been constructed as follows. For Mozambique, a price index of nontradable goods relative to tradable goods was calculated, based on the CPI index, detailed by major commodity groups. Nontradable goods are assumed to comprise health; transportation and communication; and education, recreation, and culture. Tradable goods comprises food, alcohol, and tobacco; clothing and footwear; firewood and furniture; and other goods and services. For the trading-partner countries, ${ }^{21}$ the ratio of CPI to the wholesale price index was considered.

85. Before proceeding with the multivariate analysis, the stationarity characteristics of the series have been tested performing augmented Dickey-Fuller and Phillips-Perron tests. The results indicate that the hypothesis that the variables in the analysis are integrated of order 1 cannot be rejected. ${ }^{22}$ On the basis of Johansen's tests for cointegration, there is evidence that

\footnotetext{
${ }^{19}$ Net foreign assets of the banking system are a proxy for the net foreign assets of the entire system.
}

${ }^{20}$ In this study, the use of monthly data prevents us from considering the commonly used nominal GDP as a way to adjust for the size of the country (only annual data are available for nominal GDP). Instead, mindful of the quantity theory of money, we use broad money to make the adjustment.

${ }^{21}$ South Africa, United States, Japan, Italy, Germany, France, United Kingdom, Netherlands, Singapore, Brazil, Sweden, Belgium, Canada, Spain, Denmark, Thailand, and Korea.

${ }^{22}$ Results are available upon request. 
the system presents a cointegrating vector (Table 4); this result would imply the presence of the following long-run relationship among the real effective exchange rate, net foreign assets, and relative sectoral prices:

$$
q=0.09 n f a+0.20 n .
$$

86. Using the cointegrating vector and the loading factors of the cointegration relationship (Table 4), the real exchange rate is decomposed into a permanent and a transitory components, following Gonzalo and Granger (1995). The permanent and transitory components represent in our empirical model the real equilibrium exchange rate and deviations from equilibrium, respectively.

87. Figure 7 and Table 4 show the results. The top panel of Figure 7 displays the actual and the equilibrium effective exchange rates, and the panel at the bottom presents deviations from the equilibrium, which are the differences between the actual and the estimated equilibrium rates; the computed 95 percent standard errors bands are also reported. Values above zero suggest an overvaluation of the real effective exchange rate. Over time, the evolution of the equilibrium exchange rate shows two distinct phases. From December 1993 to January 1998 , the equilibrium exchange rate appreciated quite sharply, by about 30 percent, and, for the rest of the period, it maintained relative stability. The determinants of the equilibrium exchange rate (Figure 6) suggest that this behavior reflects in part an improvement in the net foreign assets position, in particular for the period before January 1998, which, in turn, could be related mainly to the big inflows of aid during that period that were not channeled into imports, and to the pattern of productivity in the tradable goods sector with respect to the nontradable one, as indicated by the sectoral price differential. The ratio of nontradable to tradable goods prices shows that productivity in tradable goods relative to nontradable goods declined from December 1993 to February 1996, then increased sharply until January 1997, and remained quite stable thereafter.

88. The speed with which the exchange rate approaches its equilibrium was also calculated. The speed is given by the coefficients of the loading matrix (Table 4). The results suggest that the half-life for the adjustment, that is, the time to correct the disequilibrium by 50 percent, is five months; for net foreign assets and sectoral prices, the half-life is three and two months, respectively. However, inspection of the standard errors of the loading matrix would suggest that, when the exchange rate is misaligned, the adjustments take place more in the exchange rate itself and in the sectoral prices than in net foreign assets.

89. As expected, the real effective exchange rate has fluctuated around its equilibrium level, alternating phases of overvaluation with periods of undervaluation; however, fluctuations remained within a range of 7 percent for the entire period under consideration. The most protracted period of apparent overvaluation started in July 1997 and lasted for about 15 months. This result would confirm the findings of Leite and others (1998) about the possible loss in external competitiveness that the Mozambican economy was suffering at the time-findings that led the staff team to advise the authorities to refrain from managing the 
exchange rate and to limit their intervention in the foreign exchange market to smoothing operations.

90. In subsequent months, this tendency reversed and, from October 1998, the real effective exchange rate started to depreciate moderately, so that by April 2000 it appeared to be undervalued by about 3 percent with respect to its equilibrium.

\section{E. Conclusions}

91. Based on a theoretical framework that encompasses the Balassa-Samuelson hypothesis and the balance of payments approach to the determination of the equilibrium exchange rate, this section has estimated the equilibrium exchange rate and its determinants for Mozambique over the period December 1993-April 2000. The results indicate that, overall, the equilibrium real exchange rate shows a protracted period of appreciation, from December 1993 to January 1998 , followed by a period of stability from February 1998 to April 2000. This behavior reflects in part an improvement in the net foreign assets position, in particular for the period before January 1998, which, in turn, could be mainly related to the big inflows of aid during that period, and to the pattern of productivity in the tradable goods sector with respect to the nontradable one, as represented by the ratio of nontradable to tradable goods prices.

92. Fluctuations of the observed exchange rate around its equilibrium remained contained within a range of 7 percent over the entire period. The most protracted period of apparent overvaluation started in July 1997 and lasted until October 1998, confirming the concern, expressed at the time, that the Mozambican economy was suffering from a loss in competitiveness and justifying the Fund staff's advice that the authorities pursue a floating exchange rate policy.

93. From the end of 1998 onward, the real effective exchange rate started to depreciate moderately, as the central bank refrained from intervening in the foreign exchange market. In April 2000, the real effective exchange rate appeared to be undervalued by about 3 percent. The speed with which the exchange rate approaches its equilibrium, as measured by the halflife adjustment, that is, the time needed to correct the disequilibrium by 50 percent, is estimated at about five months.

\section{References}

Alberola, Enrique, and others, 1999, "Global Equilibrium Exchange Rates: Euro, Dollar, 'Ins,' 'Outs,' and Other Major Currencies in a Panel Cointegration Framework," IMF Working Paper, 99/175 (Washington: International Monetary Fund).

Frenkel, Jacob, and Michael Mussa, 1985, “Asset Markets, Exchange Rates, and the Balance of Payments," in Handbook of International Economics, Vol. II, ed. by Gene Grossman and Kenneth Rogoff(New York: North-Holland), pp. 679-747. 
Gonzalo, Jesus, and Clive Granger, 1995, "Estimation of Common Long-Memory Components in Cointegrated Systems," Journal of Business and Economic Statistics, Vol. 13 (January), pp.27-35.

Maravall, Augustin, 1993, "Stochastic Linear Trends: Models and Estimators," Journal of Econometrics, Vol. 56 (March), pp.5-37.

Mussa, Michael, 1984, "The Theory of Exchange Rate Determination," in Exchange Rate Theory and Practice, NBER Conference Report, ed. by J. Bilson and R. Morston, (Chicago: University of Chicago Press).

Obstfeld, Maurice, and Kenneth Rogoff, 1996, Foundations of International Economics, (Cambridge, Massachusetts: MIT Press).

Leite, Sérgio Pereira, and others, 1998, "Exchange Rates and External Competitiveness in Mozambique," in Republic of Mozambique-Selected Issues, IMF Staff Country Report No. 98/59 (Washington: International Monetary Fund), pp.33-45.

Quah, Denny, 1992, "The Relative Importance of Permanent and Transitory Components: Identification and Some Theoretical Bounds," Econometrica, Vol. 60 (January), pp.107-18. 
Figure 6. Real Effective Exchange Rate and its Determinants, December 1993-April 2000
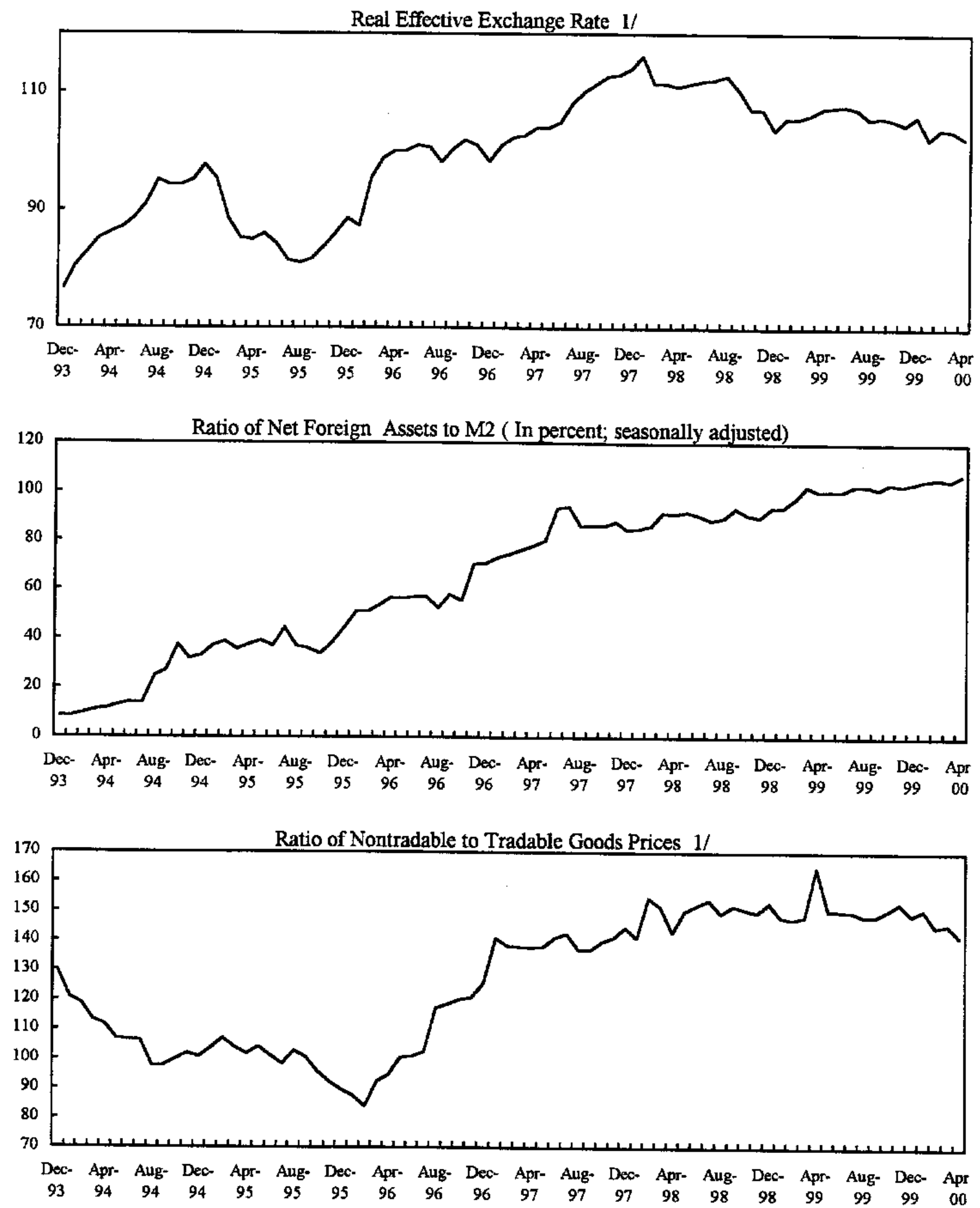

Sources: Mozambican authorities; and IMF Information Notice System.

1/ Index December 1994=100; seasonally adjusted. 
Figure 7. Mozambique: Equilibrium Exchange Rate,

December 1993-April 2000
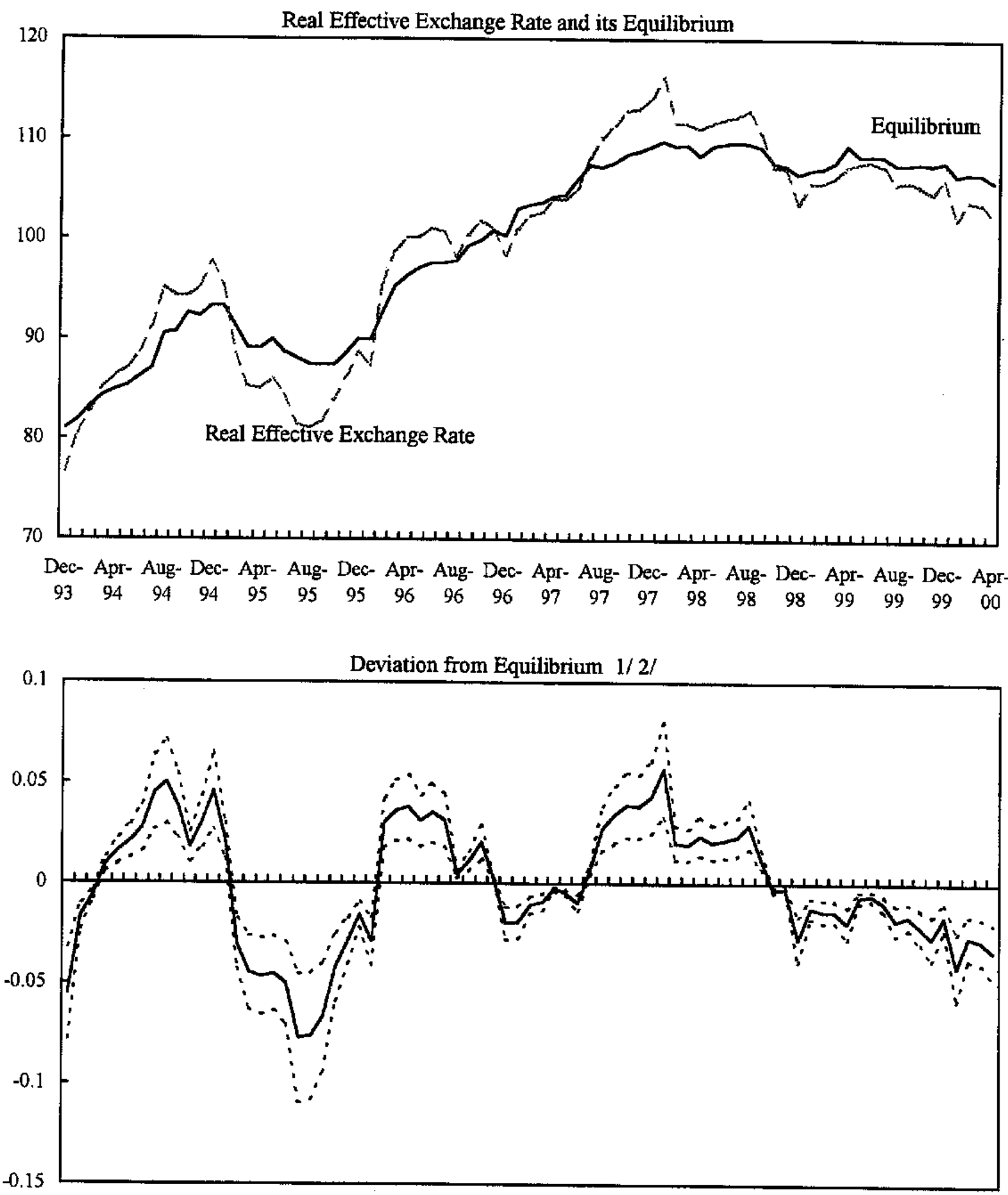

Dec- Apr- Aug- Dec- Apr- Aug- Dec- Apr- Aug- Dec- Apr- Aug- Dec- Apr- Aug- Dec- Apr- Aug- Dec- Apr-

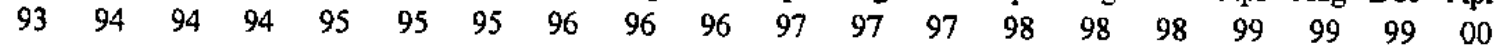

Sources: Mozambican authorities; and IMF Information Notice System.

1/ Difference between logarithms of the observed and equilibrium exchange rates.

2/ Standard errors are represented by the dotted lines. 
Table 4. Cointegration Analysis Results

\begin{tabular}{|c|c|c|c|c|}
\hline \multicolumn{5}{|c|}{ Johansen Test } \\
\hline Ho: $r<=$ & Eigenvalues & Trace & $\lambda-\max$ & Critical Value $5 \%$ \\
\hline 2 & 0.03 & 2.05 & 2.05 & 8.18 \\
\hline 1 & 0.12 & 11.24 & 9.20 & 14.90 \\
\hline 0 & 0.30 & 37.41 & 26.17 & 21.07 \\
\hline \multicolumn{2}{|c|}{ Cointegrating Vector } & \multicolumn{2}{|c|}{ Loading matrix } & \\
\hline 1.0000 & & -0.1192 & $(0.056)$ & \\
\hline-0.0920 & & 0.2165 & $(0.232)$ & \\
\hline-0.2016 & & 0.287 & $(0.102)$ & \\
\hline
\end{tabular}

Note: Standard errors are in brackets.

Table 5. Misalignments, December 1993-April 2000 (In percent)

\begin{tabular}{lrl}
\hline December 1993 & -5.5 & $(1.1)$ \\
March 1994 & 0.9 & $(0.2)$ \\
August 1994 & 5.0 & $(1.0)$ \\
February 1995 & -3.0 & $(0.6)$ \\
July 1995 & -7.7 & $(1.6)$ \\
February 1996 & 3.0 & $(0.6)$ \\
December 1996 & -2.0 & $(0.4)$ \\
July 1997 & 0.7 & $(0.2)$ \\
January 1998 & 5.7 & $(1.2)$ \\
October 1998 & -0.3 & $(0.0)$ \\
April 2000 & -3.4 & $(0.7)$ \\
\hline
\end{tabular}




\section{RuRal Poverty in MoZambiQué ${ }^{23}$}

\section{A. Introduction}

94. Mozambique is one of the poorest countries in Sub-Saharan Africa, with a GNP per capita in 1998 of US\$210 (World Bank Indicators, 2000) and 69 percent of its population, or eleven million people ${ }^{24}$, in poverty. The major challenge to poverty reduction is rural poverty, which accounts for four fifths of total poverty. This chapter describes the characteristics and causes of rural poverty and discusses the major issues to be addressed for its reduction through broad-based agricultural growth. It analyses the opportunities and constraints facing smallholder agriculture and cash cropping, which are the two main sources of economic livelihood in rural areas ${ }^{25}$.

95. Mozambique is primarily a rural country - eighty percent of the population lives in the countryside and 89 percent of the workforce are farmers. It has considerable agricultural potential and valuable natural resources, with a large quantity of arable land, hardwood forests, game, fisheries, and perennial rivers that could be used for irrigation. Yet this potential is largely untapped. Out of a total land area of 789,800 square kilometers, 45 percent is considered suitable for agriculture, but only 4 percent is presently cultivated. Cash crop production is currently a fraction of what it was prior to Independence, and many agricultural processing activities are operating well below capacity. The majority of the rural population are smallholders who are only weakly integrated into the market, and almost two thirds of them live in food-insecure households. Some natural resources are being exploited unsustainably (logging, hunting, fisheries).

96. This situation is partly the result of three decades of war (liberation wars during the 1960 s and early seventies, and a civil war during the 1980 s and early 1990s.) During the latter period, there was massive destruction of housing, communications networks, and education and public health facilities. Livestock herds were decimated and fields were abandoned. Almost half the population were affected, with over one million dead, 1.5 million refugees and 3.2 million internally displaced people. After the General Peace Agreement in 1992 and democratic elections in 1994, many of the refugees and migrants returned to the countryside, sharply increasing the area under cultivation. However, despite a considerable effort of reconstruction, much of the physical infrastructure still is deficient.

\footnotetext{
${ }^{23}$ This section was prepared by Alison Scott. Comments from the World Bank are gratefully acknowledged.

${ }^{24}$ According to the 1997 census, Mozambique has a total population of about 17 million.

${ }^{25}$ Other income-earning opportunities, such as tourism, wildlife exploitation, and fishing, which are available to some rural groups on the coast and around game parks, are not discussed here. Nor is government policy towards the agricultural sector, which would require a much longer analysis.
} 
97. Mozambique also suffers from occasional climatic shocks, such as droughts, hurricanes, and floods. For example, the floods of February and March 2000 are estimated to have resulted in some 700 deaths, displacement of 650,000 people, with severe damage to housing, public buildings, communications, and agricultural crops, livestock and infrastructure.

98. During the 1970s and 1980s, agriculture was also adversely affected by the nationalization of large agricultural estates, agricultural price and marketing controls, and macroeconomic instability. However, the policy environment is now much more favorable to agriculture. State enterprises have been privatized, the economy has been stabilized, and trade policy has become more liberal. Agricultural markets for inputs and outputs have been liberalized, and most distortionary policies reduced or eliminated.

99. In a rural country like Mozambique, broad-based agricultural growth would have a major impact on poverty reduction. It has the potential for this, but there are also formidable obstacles. The issue for government is how to raise productivity and incomes amongst smallhoiders, encourage agricultural exports and agro-processing, and promote more sustainable use of natural resources.

\section{B. The Characteristics and Causes of Rural Poverty ${ }^{26}$}

100. Table 6 sets out some summary characteristics of rural and urban poverty in Mozambique $^{27}$. This shows the overwhelming concentration of population, poverty, and

\footnotetext{
${ }^{26}$ Most of the data on poverty are based on the National Household Survey on Living Conditions, carried out between February 1996 and April 1997 with 8,274 households. The data were analyzed and published in December 1998 by staff from the Department of Population and Social Development of the Ministry of Planning and Finance (MPF), the Agronomy Faculty of Eduardo Mondlane University (UEM) and the International Food Policy Research Institute (IFPRI) (MPF/UEM/FPRI 1998). This survey is the first nationally representative poverty survey in Mozambique and the major reference point for poverty analysis. The UNDP's recent Mozambique Human Development Report presents poverty data based on the Human Development Index (HDI) and the Human Poverty Index (HPI). These are constructed from a range of secondary sources on GDP per capita, life expectancy, literacy, malnutrition, and access to health and safe water. The indices give a lower incidence of poverty ( 57 percent as against 69 percent). In addition, the results by region are both lower, and have a different ranking, from the 1997 survey (UNDP 2000).

${ }^{27}$ The reference point for these measures is the poverty line, which is based on per capita consumption, and is defined as the sum of the food and non-food poverty lines. The food poverty line is anchored on the minimum energy needs for age- and sex-specific groups recommended by WHO, and supplemented with calculations of the calorific intake of a typical diet of the poor and the average cost of a calorie in this diet. Adjustments are made for regional differences in diet and the cost of living. The non-food poverty line is determined by analyzing the pattern of consumption of non-food items (e.g. housing, water, clothing, transport, etc.) amongst households whose total consumption was within 20 percent of the food poverty line (MPF/UEM/IFPRI 2000, chapter 1). The headcount index measures the proportion of the population whose per capita consumption is below the poverty line. The poverty gap index measures the depth of poverty, i.e. the gap between the poor's average consumption level and the poverty line (expressed as a proportion of that line). The squared poverty gap index adjusts this figure for differences amongst the poor, and is a measure of the severity of poverty.
} 
extreme poverty in rural areas. The social indicators (illiteracy, infant mortality, malnutrition, and access to safe water) are all much worse in the countryside than in towns. However, although the poverty rate is less in urban areas, the depth and severity of poverty are similar in both areas. The table also shows how rural poverty dominates the national figures on poverty, because it is such a large proportion of the total population.

101. Table 7 provides a further disaggregation of these data, comparing the information for the rural and urban poor, and the national total. The rural poor are significantly worse off than the urban poor. They have extremely low levels of education (only one third are literate, and a tenth have completed primary education), less than half the children are enrolled in primary school, two fifths of children under five years have not been vaccinated, and only a tenth of households have access to safe water. Nearly half of the fertile age women have had one or more child who died. They are also less likely to speak the official language, Portuguese. The low social indicators of the rural poor reflect their lack of access to services. Their average distance to a primary school is 4.5 kilometers, a health post is $19 \mathrm{~km}$., a pharmacy is $29 \mathrm{~km}$., and a doctor is $46 \mathrm{~km}$.

102. While the social indicators for the urban poor are better than for the rural poor, they are far from satisfactory. For example, only 43 percent of the urban poor have completed primary education or higher, around 40 percent of their children are not enrolled in primary school, and only around half have access to safe water and adequate sanitation.

103. Significant gender differences are evident in these tables, amongst both the rural and the urban poor. Overall, only 22 percent of women are literate, compared with 59 percent of men, and literacy amongst rural women is staggeringly low (15 percent). Very few of them speak Portuguese. Even among the urban poor, the gap between men's and women's education levels persists.

104. Table 8 shows the employment characteristics of the rural and urban poor. The rural poor are overwhelmingly engaged in agriculture (96 percent) and informal employment (95 percent). ${ }^{28}$ It should be noted that almost half the urban poor are also engaged in agricultural activities, reflecting the importance of peri-urban agriculture in the smaller towns, and they are similarly concentrated in the informal sector. In fact, the proportions of the self-employed are the same in both groups - only unpaid family labor is less important amongst the urban poor. However, it is probable that these figures underestimate a significant amount of casual and seasonal work in both areas.

\footnotetext{
${ }^{28}$ One definition of informal employment aggregates self-employment, unpaid family labor, and domestic service. Other definitions are based on enterprise size (< five employees) or legality (formally registered enterprise). No data are available for the latter two definitions.
} 
105. There are significant regional differences in poverty, with much higher rates in the central provinces - these ones bore the brunt of the civil war, are more isolated, and have less favorable farming conditions. ${ }^{29}$

106. The MPF/UEM/IFPRI report presents the results of a multivariate regression analysis to analyze the determinants of consumption and poverty. The major variables included: household size and composition, educational attainment, employment, agricultural production and community infrastructure and access to services. Separate models were run for rural and urban areas and for five regions. The nural model had an overall $r 2$ of 0.538 and showed that smaller household size (especially fewer adults), higher educational levels (particularly of the mother), employment diversification, and use of agricultural inputs had a positive effect on per capita consumption and were statistically significant (MPF/UEM/IFPRI 1998 , chapter 3 ). This would suggest that a strategy to reduce rural poverty would need to include measures to improve both rural livelihoods and access to social sector services.

\section{The Role of Agriculture}

107. Agriculture plays a key role in the economy; it is a major source of livelihood, and food represents over two thirds of total consumption, especially among the rural poor (amongst whom it accounts for 71 percent). It also contributes to manufacturing output, of which food processing represents 26 percent. However, agriculture makes a relatively small contribution to GDP and exports (28 percent and 23 percent respectively in 1998), considering that 89 percent of the workforce are farmers.

108. Agricultural growth was high during the mid-1990s, as a result of the increased area under cultivation, initial infrastructure repairs, favorable weather, liberalization of prices, and macroeconomic stabilization. However, these were largely once-off gains associated with the return of war refugees and policy reforms, and such growth rates are not considered to be sustainable (World Bank, 2000).

109. There are large regional differences in agricultural production because of differences in ecology, climate, soil fertility and population density. The most fertile area is in the northern provinces, where food and cash crops are grown. In the drier provinces towards the south, food crops are less easily grown and cash crops such as sugar depend on irrigation. These areas are more sparsely populated and have a tradition of male outmigration to South Africa and Zimbabwe.

\footnotetext{
${ }^{29}$ The headcount ratios are highest in Sofala ( 88 percent), Inhambane ( 83 percent), and Tete ( 82 percent), compared with Nampula and Zambezia (68 percent) and Cabo Delgado (57 percent). The index for Maputo city was 48 percent. Note that according to the Human Poverty Index, Zambezia and Cabo Delgado are the poorest provinces (UNDP 2000).
} 
110. Agriculture in Mozambique is dominated by the smallholder sector. About 95 percent of agricultural value added is generated by smallholders (of which 39 percent is for own consumption) and only 5 percent by large-scale agriculture (World Bank, 2000, table 1.6). Table 9 presents data for 1999 on the production of different crops, their share of agricultural value and the proportion produced by smallholders ${ }^{30}$. It shows that basic food crops predominate both in terms of volume ( 78 percent) and value (58 percent), although this subsector is probably even larger because of an under-reporting of subsistence production. Export crops are 39 percent of total production, and only 3 percent are industrial crops.

111. The smallholder sector accounts for nearly half of total production by volume, particularly in basic foods where the proportion is 78 percent. Smallholders are also important in the production of export crops, particularly in cashew and cotton. The aggregate figures are misleading because of the inclusion of sugar, which is a plantation crop (very little of which is exported). Excluding sugar, almost three quarters of export crops are produced by smallholders.

112. Large-scale commercial farming has declined in importance since the 1970s, when cash crops were almost two thirds of exports. The decline started with the exodus of Portuguese and other settlers after Independence, which signified a major loss of managerial and technical staff. It was hastened by nationalization, poor management, inappropriate investments in plant and machinery, misguided policies (overvalued exchange rates, low administered prices, marketing controls), declining international prices, and sabotage during the civil war. Today most of the companies have been privatized, but are struggling with obsolete machinery, weak markets, and low competitiveness.

113. There is little landlessness in Mozambique. Almost 90 percent of nural households have one plot of land (machamba) and 10 percent have two or more. After Independence in 1975 , land became the property of the state. Despite recent improved legislation ${ }^{31}$, there is still some ambiguity over land rights. Currently the law still does not allow for freehold tenure; traditional communal rights to land are recognized in law, although mechanisms to enforce them are for the most part absent. In addition, there is some inequality in land holding amongst small farmers, particularly in the northern provinces (UNDP 2000: 57). Provision is made for long-term leases ( 50 years), but the conditions for lease holding are unclear and the procedures for granting land use permits lengthy and bureaucratic ${ }^{32}$ The lack of a legal land market and the inability to use land for collateral is a serious deterrent to private sector investment and the development of rural financial markets.

\footnotetext{
${ }^{30}$ Livestock are not included in Table 9. In value terms, chicken were most important ( 72.3 percent). By volume (tons), chicken and sheep predominated with 41 percent each. Cattle stocks were still very depleted.

${ }^{31}$ Land Laws were passed in 1979, 1986, and 1997

32 In late 1999, there was a backlog of 10,000 applications for permits (World Bank 2000).
} 
114. The major obstacles to agricultural growth are weak market integration, poor infrastructure, low productivity, and poor quality human resources. Population density is very low in Mozambique - around twenty inhabitants per square kilometer - and communications are poor. Most roads are poorly maintained, steam railways are barely functional, and ports are in poor condition. There is seasonal collapse of roads, bridges, and communications during the rainy season. Public transport is scarce. As a result of these infrastructure problems, input prices are high and farm gate prices are low. Agricultural yields are well below those in neighboring Malawi, Zambia and Zimbabwe (World Bank 2000). This is a result of low use of agricultural inputs, plant disease, and a lack of agricultural extension. As most farmers are illiterate or have little primary level education, their ability to access agricultural extension and innovation is restricted. Even with low yields, however, many farmers have unsold surpluses.

115. Agricultural markets are weakly developed. There is little linkage between food surplus areas in the north and food deficit areas in the south. It is easier for farmers in the north to sell their products in neighboring countries, and for Maputo to import food from Swaziland and South Africa ${ }^{33}$. There is significant informal cross-border trade to Malawi and Tanzania, (which is not registered in the national statistics), much of it carried out on bicycles and in small trucks. However, this is discouraged by restrictive regulations and administrative interventions. Further away from the borders, agricultural markets are small and locally confined. Rural financial markets are almost completely absent, and access to credit has depended on institutional arrangements within cotton outgrowing schemes (see below). Donors and NGOs have been promoting the formation of farmers' associations in order to improve access to markets, but these are for the most part small in scale.

\section{The Smallholder Sector}

116. The striking characteristic of the smallholder sector in Mozambique is the small size of the plots, low input use, and low productivity. Table 10 shows that almost all farmers have access to land, but the plots are small (average 2.5 hectares per household). Most of the farms are rain fed - only 3 percent have some irrigated land. Very few use fertilizer and/or pesticides, simple machinery, or even animal traction. Almost all rely on their own household labor or family exchanges of labor, only 9 percent hire agricultural laborers.

117. Most of the farmers produce food for their own consumption and sell very little of it to the market ${ }^{34}$. On average, only 28 percent of food consumed by the rural poor is purchased, most of it comes from their own land or is exchanged through barter or direct transfers. In the northern provinces, small farmers also engaged in cash crop production (cotton, cashew), which they combine with their subsistence crops. In the south, subsistence production is

\footnotetext{
${ }^{33}$ Mozambique's coast is 2,500 kilometers long, as the crow flies.

${ }^{34}$ For example, almost 80 percent grow maize, but only 8 percent sell it; 61 percent grow cassava, but only 3 percent sell it, and 56 percent grow beans, but only 4 percent sell them (MPF/UEM/IFPRI 1998).
} 
combined with casual labor in nearby towns and male migration. A variety of localized petty trading and food processing is common in most rural areas (Dos Santos and Mead 1997). There are important differences in the roles of men and women in agriculture, with women primarily responsible for food crops (particularly maize and cassava), both men and women involved in cash crops (Arndt and Tarp, 2000), and men and women involved in separate artisanal and trading activities. Survival strategies for those near the breadline, especially during the lean pre-harvest months, include mutual help amongst kinsmen and remittances (Rose and others 1999). Box 2 provides an illustration of these livelihood strategies.

\section{E. Cash Crops}

118. The historical height of cash cropping in Mozambique was in the early 1970s, when it accounted for around two thirds of total export revenue and one third of industrial output. However, for reasons outlined above, the sector declined dramatically over the next two decades. As part of its strategy for agricultural development, the government has attempted to revive both cash crop production and agro-processing, with some recent success. However, some of the policy instruments used have proved politically contentious creating uncertainty in the relevant industries. Below the three major cash crops are discussed ${ }^{35}$.

119. Cashew is Mozambique's most important cash crop among an estimated million rural households. ${ }^{36}$ In 1998 , cashew nuts were the second export product after prawns. However, cashew yields are low and many trees are diseased. Mozambique also has a cashew processing industry, with fifteen plants employing some 8,000 workers, which export to the United States and South Africa. However, many of the plants are uncompetitive and five have ceased operations. On the other hand, some newer, smaller plants are competitive and growing. Between 1978 and 1994, a ban on the export of raw nuts was in place; this was replaced by an export tax of 30-40 percent of the fob price in 1994/5, reduced to 20 percent in 1996 and 14 percent in 1997. In 1999, following protests from the industry, the export tax was raised again to 18-22 percent and local processors were given the first right to purchase raw nuts. So far, the government has maintained the export tax at 18 percent and refrained from enforcing the first right of purchase. In order to help rehabilitate the industry, it created the National Cashew Institute (INCAJU), linked to the Ministry of Agriculture. Under its leadership, a master plan has been prepared to improve the production, marketing, and processing of cashew nuts. As part of a program of support to the industry, uncompetitive plants will be assisted with the severance obligations of their workers and thus be able to close down, while other plants with more potential will be helped to restructure.

\footnotetext{
${ }^{35}$ Other cash crops include tea, tobacco, sunflower, copra, sisal, and citrus fruit.

${ }^{36}$ During the 1970s, Mozambique was the world's leading producer of cashew nuts. But production dropped from more than 200,000 tons per annum to 32,000 tons in the early 1990 s.
} 
120. Studies from the Agricultural Market Information System (SIMA) show that both producer and wholesale prices almost doubled between the 1997/98 and 1998/99 harvests, and smallholders started to spend more time pruning and cleaning their cashew trees (Mole and Weber, 1999). However, prices are subject to strong fluctuations, driven above all by exports (reportedly, prices soar when ships for exports arrive). With external assistance, INCAJU has started spraying against plant disease and is providing extension services to farmers through NGOs. Prospects for the cashew industry have improved now that the government has clarified its policy for the sector and is providing technical support to raise productivity.

121. Cotton is now the second most important agricultural export after cashew, supporting about 250,000 smallholders and more than 10,000 workers. It also had suffered a dramatic decline since the 1970s. In 1990, the government opened up the sector to private operators under a concession regime, establishing Joint Venture Companies (JVCs) with three multi-national agribusiness companies. Under these regimes, smallholders must sell their cotton to the JVC operating in their area; in return, the company undertakes to purchase their entire crop at the minimum prices fixed annually by the government, and to provide credit, inputs, and extension services for cotton and food crops, as well as to invest in the rehabilitation of cotton ginneries and rural road networks in their area of influence. As a result, cotton cultivation has expanded considerably, and production trebled between 1990 and 1998 (European Commission 1999). Farmers' per capita incomes rose by between 25 and 36 percent with low input cotton production and between 97 and 138 percent with high input cotton, relative to non-cotton growers (MAP/MSU 1997).

122. Smallholders account for about 85 percent of total seed cotton production and productivity is extremely low. This is due to limited use of improved varieties, late planting, insufficient weeding and inappropriate insecticide application. Nevertheless, cotton is the only crop for which a specialized input supply and extension network exists and research has shown significant productivity increases on both cotton and food crops in the JVC areas. ${ }^{37}$ Moreover these areas have benefited from the increased investment in rural roads (MAP/MSU 1997). However, there have been criticisms of the companies' supply of inputs, extension, and marketing, and there is growing evidence of an increased demand for farmers' output from independent operators. In 1998, the government relaxed the requirement to sell to the JVCs for farmers with over twenty hectares, and is currently considering revising further the contract arrangements between the JVCs and the farmers. Overall, the prospects for cotton are good, but are dependent on a highly volatile world market, where prices have recently been depressed. However, there is continuing interest from foreign investors in the sector.

\footnotetext{
${ }^{37}$ The MAP/MSU research in Nampula and Cabo Delgado show that fertilizer use increased yields in maize as well as cotton, because of switching crops between fields.
} 
123. Sugar is another traditional crop in Mozambique that has experienced a massive decline since the 1970s, when it was the third most important export. Production fell from 325,000 tons in 1972 to 13,500 in 1992, and the workforce fell from 45,000 to around 12,000 . The country became a net importer of sugar. ${ }^{38}$ The industry suffered particularly from damage to plant and equipment during the civil war, and only two companies were in operation by 1998. The government developed a strategy to rehabilitate the industry in the mid 1990s, because of its perceived comparative advantage in terms of local agro-ecological conditions and its potential as a low cost producer. Increased domestic sugar production would also improve the balance of trade through import substitution and would promote poverty reduction in rural areas through employment generation. Given the dependence on foreign capital and technical know-how, the focus for rehabilitation was privatization coupled with protection incentives in the form of surcharges on sugar imports.

124. Mozambique currently has six vertically integrated sugar estates and mills, with a total area of 52,800 hectares (small by international standards), and a total estimated capacity of 415,000 tons per year. Four of these have been targeted for rehabilitation. The privatization process has been underway since 1992, with investments by South African, Mauritian, and Mozambican companies and the IFC. Various donors have provided soft loans. As a result of these investments, sugar production has risen to more than 50,000 tons and the workforce to over 17,000 permanent and casual workers. Due to the recent floods, production is expected to fall by 40 percent in 2000 and 30 percent in 2001 , but revised estimates are predicting that production will reach almost full capacity by 2005 .

125. Following IMF concern over the extension of import surcharges on sugar, against agreements to reduce tariff protection, the government agreed to undertake a review of current sugar policy. The FAO led the review, with inputs from two private sugar consulting firms and funding from the UNDP. The report concluded that the sugar industry would be internationally competitive once the rehabilitation process was complete (in 2004), and that the import surcharges were necessary in the meantime because of distortions in the international sugar market. It did however, recommend that the level of protection should be reviewed as the industry became more competitive, and that an independent monitoring and evaluation system should be set up. Following this report, the government has maintained the sugar surcharges at their current levels.

126. The FAO report assumes that the internal market would absorb most of the sugar output and its growth would exceed that of GDP. However, at present Mozambique's sugar market is relatively small, while opportunities in the external market appear to be limited and uncertain. Although the authorities see export opportunities in the region, Mozambique may still be dependent on a volatile world market, especially during the early years while the

\footnotetext{
${ }^{38}$ Mozambique is currently importing more than 100,000 tons of sugar annually, while it is exporting 15,000 tons to the USA under a preferential agreement.
} 
internal market was still developing. At recent world market prices, this surplus would have to be exported at a loss to the industry.

127. In terms of job creation, the FAO report estimates that 6,000 new full-timeequivalent jobs would be created by 2010 , in addition to the current 10,000 jobs. However, these figures are based on an assumed plantation mode of production, with considerable reliance on casual labor. While this could provide a boost to the local economy as a supplement to current smallholder activities, such jobs are increasingly being mechanized these days. The income-employment multiplier would be greater if outgrower schemes were used. In any event, the fact that sugar production is located in the central-southern areas of the country where there are fewer opportunities for agricultural production, would be bound to have a positive effect on poverty reduction. However, of the three cash crops considered here, sugar has the most precarious growth potential because of uncertainties in the internal and international market.

\section{F. Conclusion}

128. Both government and donors in Mozambique are convinced of the need to promote agricultural growth and rural development in order to make a substantial impact on poverty reduction. The national Poverty Reduction Strategy Paper (PRSP/PARPA) rightly targets the smallholder population for support. The agricultural sector strategy also identifies the need to encourage agricultural exports and agro processing. But it will not be easy to achieve immediate impacts in these sectors.

129. Resolving basic problems of infrastructure and transport in order to develop markets is costly and takes time. Equally, improving agricultural productivity requires extension activities coupled with financial support for the purchase of inputs. At present, the government has withdrawn somewhat from these areas and the private sector has not stepped in to fill the gap. Reliance on donors is not sustainable in the long run. Moreover, farmers have little incentive to improve their yields if they cannot sell the output. In the long run, the internal market would be unlikely to be able to absorb a substantial increase in the volume of production, because of the small size of the population and inequalities in income. Therefore, cash crop production for export will need to play a key role in the sector. Preferably this should be in new high value crops that are less prone to unstable international prices than the traditional crops. New developments in tourism and wildlife management also offer potential. Plans are underway to combine South Africa, Swaziland and Mozambique in a single wildlife protection/tourism area, for the benefit of both the environment and rural livelihoods. Finally, human resources would need to be improved in rural areas, so that farmers can enjoy better health and engage with new technologies, thereby both improving their quality of life and contributing to broad-based agricultural growth. 


\section{References}

Arndt, C., and F. Tarp, 2000, "Agricultural Technology, Risk and Gender: A CGE Analysis of Mozambique," World Development, Vol. 28 (No. 7), pp. 1307-26.

Dos Santos Benfica, R., and D. Mead, 1997, "Micro and Small Enterprises in Central and Northern Mozambique: Results of a 1996 Survey," MOA/MSU Research Working Paper No. 27.

European Commission, Food Security Unit, 1999, "Cashcropping in Mozambique: Evolution and Prospects," Technical Paper No. 2.

MAP/MSU (Ministry of Agriculture and Fisheries/Michigan State University), 1997, "Smallholder Cash-Cropping, Food-Cropping and Food Security in Northern Mozambique: Summary, Conclusions and Policy Recommendations," Working Paper No 25, (Lousing, Michigan: Michigan State University).

Mole, P., and M. T. Weber, 1999, "The Cashew Debate in Mozambique: Are There Alternative Strategies?" Research Findings from the Food Security Project in Mozambique, Flash report No. 16E, Ministry of Agriculture.

MPF/UEM/IFPRI, 1998, Understanding Poverty and Wellbeing in Mozambique: The First National Assessment (1996-97), (Maputo, Mozambique).

Rose, D., and others, 1999, "Household Food Consumption in Mozambique: A Case Study in Three Northern Districts," MAP/MSU Research Report No. 33.

Waterhouse, R., 1997, "Gender Relations and the Allocation and Control of Land and Agricultural Resources in Ndixe Village: A Case Study of Ndixe Village, Maputo Province, Southern Mozambique" Action Aid.

World Bank, 2000, "Mozambique: Growth Performance and Reform Agenda" (unpublished; Maputo, Mozambique: World Bank).

UNDP, 2000, Mozambique: National Human Development Report, (Maputo, Mozambique: UNDP). 


\section{Box 2. Rural Livelihood Strategies in Ndixe Village, Maputo Province ${ }^{1 /}$}

"A common pattern in Ndixe village was migrant labor combined with farming on the rural homestead, often involving livestock (goats and/or cattle). This was possible through the typical gender division of labor, whereby men migrated for waged work while women held the rural fort. The key problems for agriculture in Ndixe include the wartime loss of resources, except for the land itself, and post-war incapacity to replace them. Thus, before the war, some half of the local families had cattle, sometimes up to 50 head. In 1997, however, only four men owned any cattle (and none more than four animals), only two had ploughs. One of these had a cart, and that farmer was the only one in Ndixe who claimed to market a cultivated crop. Farm income alone was thus unable to secure agricultural growth or investment.

Male migration or absenteeism continues to be a key feature of the local economy, but a gradual breakdown in the migrant labor system and heavy losses in the urban job market has led to a rise in the number of men engaged in cultivation; but often supplemented by casual or irregular labor outside Ndixe andior by selling firewood and charcoal.

Land availability is a key feature in the lives of women who spend so much of their time working on and producing from it. Nonetheless, farming is no longer the sole productive activity of women. Displacement to urban and peri-urban areas during wartime isolated many women from production on the land. As an alternative they often turned to petty trade. Post-war, many women have maintained their links with urban resources, services and markets, through kinship networks and informal marketing. In the absence of a marketable crop surplus, the other main source of income for women is remittances from wage earners in the city. Beyond this, the main alternative sources of cash for women are: gathering and marketing wild fruits and vegetable leaves, xitoco (manual labor on another person's field, paid for in cash or kind), wood cutting and beer brewing."

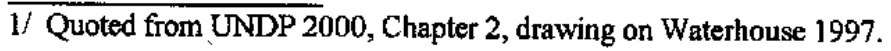


Table 6. Mozambique: Poverty Statistics

\begin{tabular}{lrrr}
\hline & Rural & Urban & National \\
\hline & & & \\
Distribution of population (percent) & 79.7 & 20.3 & 100.0 \\
Distribution of the poor (percent) & 82.0 & 18.0 & 100.0 \\
Distribution of the ultra poor (percent) & 81.8 & 18.2 & 100.0 \\
Proportion of the total population who are poor & 71.2 & 62.0 & 69.4 \\
(headcount ratio) & & & \\
Poverty gap index & 29.9 & 26.7 & 29.3 \\
Squared poverty gap index & 15.9 & 14.6 & 15.6 \\
Percent literate (15+ years) & 32.0 & 71.0 & 40.0 \\
(men) & 52.3 & 85.1 & 59.3 \\
(women) & 15.7 & 57.6 & 23.6 \\
Percent of children (under 5 years) with chronic & 48.1 & 27.6 & 43.2 \\
malnutrition (stunted) & & & \\
Percent without access to safe water & 88.5 & 46.4 & 79.9 \\
Infant mortality rate (from DHS, 97) & 160.0 & 101.0 & 147.0 \\
& & & \\
\hline Source: MFP/UEM/FPRI (1998) Tables 2.1,2.2.5.2.10 & & &
\end{tabular}

Table 7. Mozambique: Poverty Characteristics of the Rural and Urban Poor, compared with the National Total (percentages)

\begin{tabular}{lccc}
\hline & Rural poor & Urban Poor & National \\
\hline & & & \\
Literacy & 31.2 & 61.8 & 40.0 \\
(men) & 50.9 & 78.9 & 59.3 \\
(women) & 15.1 & 46.4 & 23.6 \\
Boys aged 7-11 enrolled in school & 47.2 & 66.8 & 53.9 \\
Girls aged 7-11 enrolled in school & 36.5 & 59.9 & 44.7 \\
Speaks Portuguese & 39.4 & 77.5 & 49.7 \\
(men) & 60.3 & 90.6 & 69.3 \\
(women) & 22.2 & 65.5 & 32.7 \\
Children (under 5 yrs) with a health card & 55.1 & 87.2 & 62.6 \\
Children (under 5 yrs) without any vaccination & 41.5 & 12.6 & 34.3 \\
Women (12-49 years) with one or more & 48.2 & 36.1 & 46.1 \\
children who died & & & \\
Dwellings with a latrine & 27.4 & 55.1 & 33.0 \\
Households with electricity or gas for cooking & 0.4 & 3.7 & 2.6 \\
Households with piped water & 10.1 & 46.9 & 20.1 \\
Households taking water from river or lake & 39.4 & 5.3 & 31.4 \\
\hline Source: MFP/UEM/EPRI (1998) Tables 2.10, 2.11, 2.12, 2.37, 2.42,2.44, 2.45 & &
\end{tabular}

Source: MFP/UEM/FPRI (1998) Tables 2.10, 2.11, 2.12, 2.37, 2.42, 2.44, 2.45 
Table 8. Mozambique: Employment of the Rural and Urban Poor

\begin{tabular}{lrr}
\hline & Rural Poor & Urban poor \\
\hline Employment sector & & \\
Agriculture & 95.8 & 55.6 \\
Manufacturing & 1.6 & 9.6 \\
Construction/transport & 0.6 & 27.1 \\
Commerce/services & 2.1 & 7.7 \\
& & \\
Occupational category & & \\
Public sector & 2.3 & 19.2 \\
Private sector, cooperatives & 2.1 & 12.0 \\
Self employment & 45.2 & 45.5 \\
Unpaid family labor & 50.2 & 21.4 \\
Employer & 0.1 & 0.9 \\
Domestic servants & 0.1 & 1.0 \\
\hline Source: MFP/UEM/IFPR (1998) Tables 2.17, 2.19 & &
\end{tabular}

Table 9. Mozambique: Agricultural Production, 1999

\begin{tabular}{|c|c|c|c|}
\hline Crop & $\begin{array}{l}\text { Distribution } \\
\text { by value } \\
\text { (percent) }\end{array}$ & $\begin{array}{l}\text { Total volume } \\
\text { (tons) }\end{array}$ & $\begin{array}{l}\text { Proportion of total } \\
\text { volume produced by } \\
\text { smallholders }\end{array}$ \\
\hline Export products & 39.2 & 694,880 & 23.7 \\
\hline Cotton & 17.3 & 106,741 & 78.3 \\
\hline Cashew & 13.1 & 58,720 & 100.0 \\
\hline Copra & 3.8 & 44,416 & 50.0 \\
\hline Sugar & 3.5 & 469,456 & 0.0 \\
\hline Citrus & 1.4 & 10,180 & 2.8 \\
\hline Tea & 0.0 & 5,367 & 0.0 \\
\hline Basic foods & 57.9 & 576,510 & 78.1 \\
\hline Maize & 23.1 & 304,117 & 85.9 \\
\hline Beans & 11.4 & 68,052 & 77.2 \\
\hline Rice & 3.7 & 28,877 & 58.4 \\
\hline Manioc & 6.1 & 83,781 & 75.5 \\
\hline Peanuts & 6.0 & 26,436 & 96.4 \\
\hline Vegetables & 5.4 & 51,000 & 47.1 \\
\hline Onions & 1.6 & 8,500 & 17.6 \\
\hline Sorghum & 0.6 & 5,747 & 88.7 \\
\hline Industrial products & 3.0 & 38,134 & 5.9 \\
\hline Tomato & 2.3 & 12,200 & 11.5 \\
\hline Tobacco & 0.5 & 700 & 0.0 \\
\hline Sunflower & 0.1 & 570 & 29.8 \\
\hline Sisal & 0.1 & 24,000 & 0.0 \\
\hline Mafurra fruit & 0.0 & 664 & 100.0 \\
\hline Total & 100.1 & $1,309,524$ & 47.1 \\
\hline
\end{tabular}

Source: Ministry of Agriculture, Ministry of Finance 
Table 10. Mozambique: Farming Characteristics of the Rural and Urban Poor

\begin{tabular}{|c|c|c|}
\hline Household farming characteristics & Rural Poor & Urban poor \\
\hline Percentage households with agricultural land & 98.9 & 62.5 \\
\hline Average hectares per household & 2.5 & 1.8 \\
\hline Households with some irrigated land & 2.8 & 5.5 \\
\hline Uses some tools and equipment & 8.4 & 8.3 \\
\hline Uses animal traction & 5.1 & 1.4 \\
\hline Has a tractor & 1.4 & 3.9 \\
\hline Uses fertilizer and/or pesticides & 1.4 & 3.1 \\
\hline Hires agricultural laborers & 9.3 & 17.6 \\
\hline Has fruit trees & 54.3 & 47.3 \\
\hline Has cashew trees & 25.9 & 9.4 \\
\hline Cultivates cotton & 3.4 & 0.5 \\
\hline $\begin{array}{l}\text { Food consumption as percentage of total } \\
\text { consumption }\end{array}$ & 70.7 & 61.8 \\
\hline Source of food: own production & 29.4 & 10.0 \\
\hline Source of food: purchased & 27.6 & 78.3 \\
\hline Source of food: transfers, etc. & 42.9 & 11.7 \\
\hline
\end{tabular}

Source: MFP/UEM/FPRI (1998) Tables 2.21, 2.22, 2.23, 2.24, 2.28, 2.31 
Table 11. Mozambique: Gross Domestic Product, 1995-99

\begin{tabular}{|c|c|c|c|c|c|}
\hline & 1995 & 1996 & 1997 & 1998 & 1999 \\
\hline & \multicolumn{5}{|c|}{ (In billions of meticais) } \\
\hline Total consumption & 21,353 & 33,317 & 40,183 & 43,101 & 47,425 \\
\hline Private consumption & 19,667 & 30,692 & 36,528 & 38,635 & 41,809 \\
\hline Public consumption & 1,686 & 2,625 & 3,655 & 4,466 & 5,616 \\
\hline Total investment $2 /$ & 6,041 & 6,845 & 7,427 & 10,887 & 16,558 \\
\hline Public investment & $\cdots$ & $\ldots$ & $\ldots$ & $\ldots$ & $\ldots$ \\
\hline Private investment & $\cdots$ & $\cdots$ & $\cdots$ & $\cdots$ & $\cdots$ \\
\hline Domestic demand & 27,394 & 40,162 & 47,611 & 53,989 & 63,983 \\
\hline Exports of goods and nonfactor services & 2,606 & 3,901 & 4,422 & 4,874 & 5,934 \\
\hline Imports of goods and nonfactor services & 8,410 & 11,344 & 11,478 & 12,435 & 19,090 \\
\hline \multirow[t]{2}{*}{ Gross domestic product } & 21,590 & 32,719 & 40,554 & 46,427 & 50,827 \\
\hline & \multicolumn{5}{|c|}{ (Annual percentage change) } \\
\hline \multicolumn{6}{|l|}{ Real rates of change $1 /$} \\
\hline Private consumption & -1.1 & 9.7 & 7.0 & 5.7 & 6.7 \\
\hline Public consumption & -49.1 & 12.6 & 21.0 & 8.5 & 9.4 \\
\hline Total investment & 20.9 & -8.4 & 1.9 & 41.1 & 47.1 \\
\hline Exports of goods and nonfactor services & 8.1 & 24.6 & 10.7 & 10.7 & 16.4 \\
\hline Imports of goods and nonfactor services & -22.8 & 6.5 & -3.2 & 10.2 & 43.3 \\
\hline Gross domestic product & 4.3 & 7.1 & 11.1 & 11.9 & 7.3 \\
\hline \multicolumn{6}{|l|}{ Deflators } \\
\hline Private consumption & 49.0 & 42.3 & 11.2 & 0.2 & 1.0 \\
\hline Public consumption & 90.8 & 38.2 & 15.1 & 12.6 & 14.9 \\
\hline Investment & 53.4 & 23.7 & 6.5 & 3.9 & 3.4 \\
\hline Exports & 59.2 & 20.1 & 2.4 & -0.4 & 4.6 \\
\hline Imports & 71.9 & 26.6 & 4.5 & -1.7 & 7.1 \\
\hline \multirow[t]{2}{*}{ Gross domestic product } & 53.1 & 41.5 & 11.6 & 2.4 & 2.0 \\
\hline & \multicolumn{5}{|c|}{ (In percent of GDP) } \\
\hline Total consumption & 98.9 & 101.8 & 99.1 & 92.8 & 93.3 \\
\hline Private consumption & 91.1 & 93.8 & 90.1 & 83.2 & 82.3 \\
\hline Public consumption & 7.8 & 8.0 & 9.0 & 9.6 & 11.0 \\
\hline Total investment & 28.0 & 20.9 & 18.3 & 23.5 & 32.6 \\
\hline Public investment & $\cdots$ & $\cdots$ & $\cdots$ & $\ldots$ & $\ldots$ \\
\hline Private investment & $\cdots$ & $\cdots$ & $\cdots$ & $\cdots$ & $\cdots$ \\
\hline Domestic demand & 126.9 & 122.7 & 117.4 & 116.3 & 125.9 \\
\hline Exports of goods and nonfactor services & 12.1 & 11.9 & 10.9 & 10.5 & 11.7 \\
\hline Imports of goods and nonfactor services & 39.0 & 34.7 & 28.3 & 26.8 & 37.6 \\
\hline Gross domestic product & 100.0 & 100.0 & 100.0 & 100.0 & 100.0 \\
\hline
\end{tabular}

Sources: Mozambican authorities; and staff estimates.

$1 /$ Volume growth rates based on growth of value at previous year's prices. 
Table 12. Mozambique: Savings and Investment, 1995-99

\begin{tabular}{|c|c|c|c|c|c|}
\hline & 1995 & 1996 & 1997 & 1998 & 1999 \\
\hline & \multicolumn{5}{|c|}{ (In billions of meticais) } \\
\hline Gross domestic savings (GDS) 1/ & 237 & -599 & 371 & 3,326 & 3,402 \\
\hline Public sector & $\cdots$ & $\cdots$ & $\cdots$ & $\cdots$ &,$\ldots$ \\
\hline Private sector & $\cdots$ & $\cdots$ & $\cdots$ & $\cdots$ & $\cdots$ \\
\hline \multicolumn{6}{|l|}{ Net factor income from abroad $2 /$} \\
\hline and net unrequited transfers & 2,173 & 1,581 & 1,517 & 1,998 & 4,275 \\
\hline Net factor income & -842 & -956 & $-2,095$ & $-2,556$ & $-1,875$ \\
\hline Public sector & -367 & -633 & -484 & -473 & -318 \\
\hline Private sector & -475 & -323 & $-1,611$ & $-2,083$ & $-1,557$ \\
\hline Net unrequited transfers & 3,015 & 2,538 & 3,613 & 4,554 & 6,150 \\
\hline Public sector & 1,790 & 1,981 & 3,153 & 3,466 & 5,513 \\
\hline Private sector & 1,225 & 556 & 460 & 1,088 & 637 \\
\hline Gross national savings (GNS) $3 /$ & 2,410 & 983 & 1,888 & 5,325 & 7,677 \\
\hline Public sector & $\cdots$ & $\cdots$ & $\ldots$ & $\ldots$ & $\ldots$ \\
\hline Private sector & $\cdots$ & $\cdots$ & $\cdots$ & $\cdots$ & $\cdots$ \\
\hline Foreign savings $4 /$ & 3,631 & 5,862 & 5,539 & 5,563 & 8,880 \\
\hline Gross savings & 6,041 & 6,845 & 7,427 & 10,887 & 16,558 \\
\hline Gross investment & 6,041 & 6,845 & 7,427 & 10,887 & 16,558 \\
\hline Public sector & $\cdots$ & $\ldots$ & $\cdots$ & $\ldots$ & $\ldots$ \\
\hline \multirow[t]{2}{*}{ Private sector } & $\cdots$ & $\cdots$ & $\cdots$ & $\cdots$ & $\cdots$ \\
\hline & \multicolumn{5}{|c|}{ (In percent of GDP) } \\
\hline GDS $1 /$ & 1.1 & -1.8 & 0.9 & 7.2 & 6.7 \\
\hline Public sector & $\cdots$ & $\ldots$ & $\ldots$ & $\cdots$ & $\cdots$ \\
\hline Private sector & $\cdots$ & $\cdots$ & $\cdots$ & $\cdots$ & $\cdots$ \\
\hline \multicolumn{6}{|l|}{ Net factor income from abroad $2 /$} \\
\hline and net unrequited transfers & 10.1 & 4.8 & 3.7 & 4.3 & 8.4 \\
\hline Net factor income & -3.9 & -2.9 & -5.2 & -5.5 & -3.7 \\
\hline Net unrequited transfers & 14.0 & 7.8 & 8.9 & 9.8 & 12.1 \\
\hline GNS $3 /$ & 11.2 & 3.0 & 4.7 & 11.5 & 15.1 \\
\hline Public sector & $\ldots$ & $\ldots$ & $\ldots$ & $\cdots$ & $\ldots$ \\
\hline Private sector & $\cdots$ & $\cdots$ & $\cdots$ & $\cdots$ & $\cdots$ \\
\hline Foreign savings $4 /$ & 16.8 & 17.9 & 13.7 & 12.0 & 17.5 \\
\hline Gross savings & 28.0 & 20.9 & 18.3 & 23.5 & 32.6 \\
\hline Gross investment & 28.0 & 20.9 & 18.3 & 23.5 & 32.6 \\
\hline Public sector & $\ldots$ & $\ldots$ & $\ldots$ & $\ldots$ & $\cdots$ \\
\hline Private sector & $\ldots$ & $\ldots$ & $\cdots$ & $\ldots$ & $\ldots$ \\
\hline
\end{tabular}

Sources: Mozambican authorities; and staff estimates.

1/ GDS = GDP - total consumption = goss investment + exports of goods and nonfactor services imports of goods and nonfactor services.

2/ Actual external interest payments.

3/ GNS = GDS + net factor income from abroad + net unrequited transfers.

4/ External current account, including grants (interest payments on a cash basis). 
Table 13. Mozambique: Availability and Uses of Resources, 1995-99

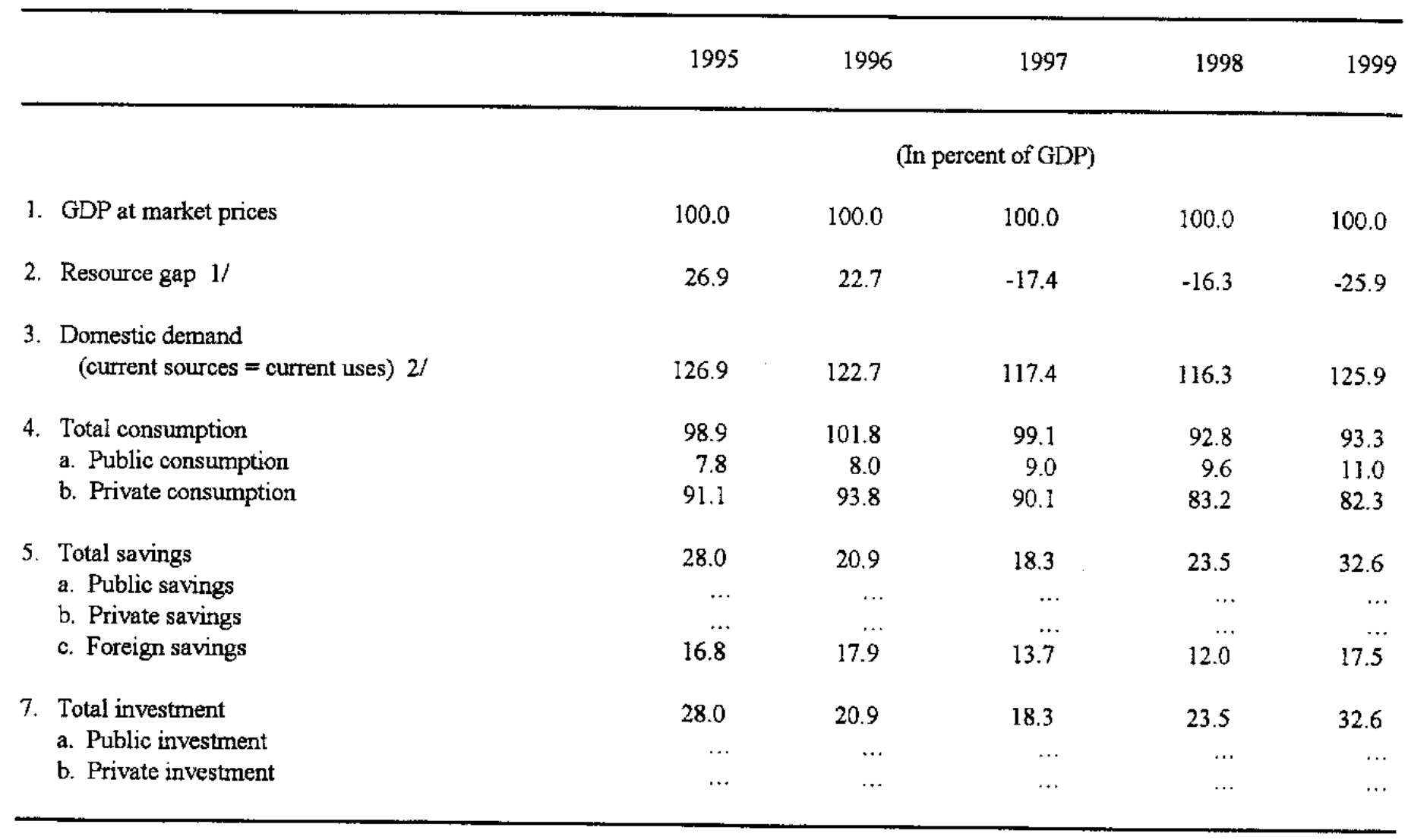

Sources: Tables 11 and 12.

$1 /$ Imports of goods and nonfactor services minus exports of goods and nonfactor services.

2/ $(3)=(1)+(2)=(4)+(5)$. 
Table 14. Mozambique: Composition of Gross Domestic Product, 1995-99

\begin{tabular}{|c|c|c|c|c|c|}
\hline & 1995 & 1996 & 1997 & 1998 & 1999 \\
\hline & \multicolumn{5}{|c|}{ (In bilions of meticais) } \\
\hline Apriculture & 6,006 & 9,969 & 12,011 & 12,670 & 13,779 \\
\hline Fishing & 985 & 1,311 & 1,549 & 1,595 & 1,557 \\
\hline Mining & 54 & 78 & 124 & $14 !$ & 104 \\
\hline Manufacturing & 1,530 & 2,822 & 3,798 & 4,805 & 4,899 \\
\hline Electricity and water & 65 & 135 & 326 & 881 & 1,390 \\
\hline Construction & 1,272 & 2,060 & 2,597 & 4,118 & 4,360 \\
\hline Business & 4,707 & 7,915 & 9,253 & 9,738 & 9,903 \\
\hline Restaurants and Hotels & 142 & 278 & 491 & 563 & 605 \\
\hline Public admiristration and defense & 749 & 860 & 1,006 & 1,278 & 1,839 \\
\hline Trarsport and communication & 1,833 & 2,826 & 4,381 & 4,522 & 4,816 \\
\hline Education Services & 310 & 461 & 608 & 852 & 1,009 \\
\hline Health services & 86 & 131 & 179 & 246 & 375 \\
\hline Other services & 3,455 & 3,929 & 4,460 & 4,957 & 5.676 \\
\hline Import rights & 588 & 685 & 812 & 954 & 1,046 \\
\hline Services of financial intermediation & .504 & .740 & $-1,040$ & -894 & -532 \\
\hline \multirow[t]{2}{*}{ Gross Domestic Praduct } & 21,277 & 32,719 & 40,554 & 46,427 & 50,827 \\
\hline & \multicolumn{5}{|c|}{ (In percent of GDP) } \\
\hline Agriculture & 28.2 & 30.5 & 29.6 & 27.3 & 27.1 \\
\hline Fishing & 4.6 & 4.0 & 3.8 & 3.4 & 3.1 \\
\hline Mining & 0.3 & 0.2 & 0.3 & 0.3 & 0.2 \\
\hline Manufacturing & 7.2 & 8.6 & 9.4 & 10.3 & 9.6 \\
\hline Electricity and water & 0.3 & 0.4 & 0.8 & 1.9 & 2.7 \\
\hline Construction & 6.0 & 6.3 & 6.4 & 8.9 & 8.6 \\
\hline Business & 22.1 & 24.2 & 22.8 & 21.0 & 19.5 \\
\hline Restsurants and Hotels & 0.7 & 0.8 & 1.2 & 1.2 & 1.2 \\
\hline Public administration and defense & 3.5 & 2.6 & 2.5 & 2.8 & 3.6 \\
\hline Trensport and comnunication & 8.6 & 8.6 & 10.8 & 9.7 & 9.5 \\
\hline Educstion Services & 1.5 & 1.4 & 1.5 & 1.8 & 2.0 \\
\hline Health services & 0.4 & 0.4 & 0.4 & 0.5 & 0.7 \\
\hline Other services & 16.2 & 12.0 & 11.0 & 10.7 & 11.2 \\
\hline Inport rights & 2.8 & 2.1 & 2.0 & 2.1 & 2.1 \\
\hline Services of financial internediation & -2.4 & -2.3 & -2.6 & -1.9 & -1.0 \\
\hline \multirow[t]{2}{*}{ Gross Donestic Product } & 100.0 & 100.0 & 100.0 & 100.0 & 100.0 \\
\hline & \multicolumn{5}{|c|}{ (Annual percentage change) } \\
\hline \multicolumn{6}{|l|}{ Real rates of change $1 /$} \\
\hline Agriculture & 17.0 & 8.7 & 9.4 & 8.9 & 9.0 \\
\hline Fishing & 2.8 & 10.2 & 1.2 & 0.5 & -4.2 \\
\hline Mining & 20.1 & -19.9 & 19.9 & 15.1 & -33.7 \\
\hline Manufacturing & 7.8 & 18.4 & 33.9 & 15.9 & 4.5 \\
\hline Electricity and water & 6.6 & 2.9 & 42.0 & 288.2 & 59.7 \\
\hline Construction & 19.0 & 18.1 & 16.5 & 36.9 & 3.1 \\
\hline Business & -0.2 & 0.7 & 8.6 & 6.1 & 6.8 \\
\hline Restaurants and Hotels & -5.3 & 18.3 & 35.3 & -2.3 & 3.1 \\
\hline Public adninistration and defense & -52.2 & -5.6 & -0.9 & 4.7 & 12.3 \\
\hline Trensport and contrunication & 11.1 & 10.1 & 17.1 & 4.5 & 3.8 \\
\hline Education Services & 10.0 & 10.2 & 7.2 & 7.4 & 9.6 \\
\hline Heatth services & 13.4 & 9.1 & 5.1 & 14.6 & 7.0 \\
\hline Other services & 22.1 & -28.2 & 3.8 & 10.0 & 5.0 \\
\hline imporț rights & 0.2 & -12.9 & 9.7 & 13.3 & 11.7 \\
\hline Services of financial internediation & 115.5 & -1.5 & 78.7 & 1.5 & -10.6 \\
\hline Gross Domestic Product & 6.3 & 3.8 & 11.1 & 11.9 & 7.3 \\
\hline \multicolumn{6}{|l|}{ Deflators } \\
\hline Agriculture & 34.6 & 52.7 & 10.1 & -3.1 & -0.3 \\
\hline Fishing & 91.3 & 20.8 & 16.8 & 2.5 & 19 \\
\hline Mining & 95.2 & 80.6 & 33.1 & -0.9 & 11.2 \\
\hline Menufacturing & 22.2 & 55.8 & 0.5 & 9.2 & -2.4 \\
\hline Electricity and water & 44.] & 103.7 & 69.7 & -30.4 & -1.2 \\
\hline Construetion & 42.9 & 37.1 & 8.2 & 15.8 & 2.7 \\
\hline Business & 70.1 & 67.0 & 3.7 & -0.8 & -4.8 \\
\hline Restaurants and Hoteis & 58.0 & 65.6 & 30.6 & 17.5 & 4.2 \\
\hline Public administration and defense & 117.8 & 21.6 & 18.0 & 21.4 & 28.2 \\
\hline Trassport and communication & 33.5 & 40.1 & 32.4 & -1.2 & 2.6 \\
\hline Education Services & $\$ 9.8$ & 34.9 & 23.2 & 30.4 & 80 \\
\hline Health services & 37.3 & 39.5 & 29.9 & 20.2 & 42.7 \\
\hline Other services & 65.2 & 58.5 & 9.3 & 1.0 & 12.9 \\
\hline Impont tights & 72.0 & 33.9 & 8.1 & 3.7 & -1.9 \\
\hline Servites of financial intermediation & 194.9 & 48.9 & -21.3 & -15.3 & -33.5 \\
\hline Gross Domestic Product & 50.3 & 48.2 & 11.6 & 2.3 & 2.0 \\
\hline
\end{tabular}

Source: Mozambican authorities.

1/ Volume growth rates based on growth of value at previous year's prices. 
Table 15. Mozambique: Production of Major Marketed Crops, 1994/95-1998/99

\begin{tabular}{|c|c|c|c|c|c|}
\hline & $1994 / 95$ & $1995 / 96$ & $1996 / 97$ & $1997 / 98$ & $1998 / 99$ \\
\hline & \multicolumn{5}{|c|}{ (In thousands of tons) } \\
\hline \multicolumn{6}{|l|}{ Export crops } \\
\hline Cotton & 51.0 & 50.5 & 74.0 & 91.0 & 106.7 \\
\hline Copra & 26.4 & 22.3 & 35.6 & 36.0 & 44.4 \\
\hline Tea (leaf) & 1.0 & 1.7 & 1.5 & .1 .5 & 5.4 \\
\hline Sugar & 313.2 & 315.9 & 278.9 & 368.7 & 469.5 \\
\hline Cashew nuts & 33.4 & 66.5 & 43.3 & $\$ 1.7$ & 58.7 \\
\hline Citrus & 11.0 & 8.0 & 10.2 & 10.2 & 10.2 \\
\hline \multicolumn{6}{|l|}{ Basic food crops } \\
\hline Maize & 168.6 & 252.7 & 256.3 & 270.2 & 304.1 \\
\hline Rice & 13.6 & 21.2 & 24.9 & 26.7 & 28.9 \\
\hline Sorghum & 1.7 & 3.9 & 4.4 & 4.1 & $\$ .7$ \\
\hline Cassava & 36.2 & 31.4 & 76.1 & 74.8 & 83.8 \\
\hline Peanuts & 18.2 & 28.9 & 23.4 & 23.8 & 26.4 \\
\hline Beans & 30.4 & 39.0 & 45.0 & 45.7 & 68.1 \\
\hline Vegetables & 30.5 & 33.3 & 50.0 & 50.5 & 51.0 \\
\hline Onions & 7.6 & 7.9 & 8.5 & 8.5 & 8.5 \\
\hline \multicolumn{6}{|l|}{ Industrial inputs } \\
\hline Sisal & 24.0 & 24.0 & 24.0 & 24.0 & 24.0 \\
\hline Tobacco & 1.1 & 0.7 & 0.7 & 0.7 & 0.7 \\
\hline Mafurra & 1.8 & 2.6 & 0.7 & 1.5 & 0.7 \\
\hline Tomatoes & 22.9 & 11.7 & 12.2 & 12.2 & 12.2 \\
\hline \multirow[t]{2}{*}{ Sunflowers } & 0.2 & 0.5 & 0.5 & 0.5 & 0.6 \\
\hline & \multicolumn{5}{|c|}{ (In billions of meticais) } \\
\hline Export crops & 174.9 & 529.9 & 552.7 & 690.2 & 773.5 \\
\hline Cotton & 68.8 & 194.4 & 241.2 & 308.5 & 341.9 \\
\hline Copra & 21.1 & 39.0 & 68.6 & 69.5 & 75.6 \\
\hline Tea (leaf) & 0.1 & 0.1 & 1.5 & 1.5 & 0.5 \\
\hline Sugar & 32.5 & 44.2 & 41.8 & 55.3 & 69.1 \\
\hline Cashew nuts & 33.4 & 232.8 & 173.3 & 227.6 & 258.6 \\
\hline Citrus & 19.0 & 19.3 & 26.2 & 27.8 & 27.8 \\
\hline Basic food crops & 379.9 & 807.7 & 859.6 & 931.1 & $1,143.9$ \\
\hline Maize & 143.3 & 368.9 & 307.6 & 354.1 & 456.6 \\
\hline Rice & 17.0 & 41.6 & 97.7 & 105.2 & 72.3 \\
\hline Sorghum & 1.3 & 7.6 & 9.4 & 8.8 & 12.3 \\
\hline Cassava & 37.3 & 21.0 & 60.2 & 67.3 & 121.3 \\
\hline Peanuts & 43.6 & 107.0 & 94.1 & 95.9 & 119.1 \\
\hline Beans & 63.9 & 159.3 & 148.6 & 150.9 & 224.8 \\
\hline Vegetables & 52.5 & 69.8 & 104.6 & 117.0 & 106.9 \\
\hline Onions & 21.0 & 32.6 & 37.4 & 31.9 & 30.6 \\
\hline Industrial inputs & 73.1 & 52.8 & 56.9 & 49.8 & 57.9 \\
\hline Sisal & 0.8 & 1.1 & 1.1 & 1.1 & 1.1 \\
\hline Tobacco & 8.5 & 8.7 & 9.2 & 9.6 & 9.2 \\
\hline Mafurra & 0.6 & 1.1 & 0.4 & 0.7 & 0.3 \\
\hline Tomatoes & 63.1 & 40.6 & 44.9 & 36.9 & 45.8 \\
\hline Sunflowers & 0.2 & 1.2 & 1.4 & 1.5 & 1.5 \\
\hline Total production & 628.0 & $1,390.4$ & $1,469.2$ & $1,671.0$ & $1,975.3$ \\
\hline \multirow{2}{*}{\multicolumn{6}{|c|}{$\begin{array}{l}\text { Memorandum item: } \\
\text { Total production (in millions of }\end{array}$}} \\
\hline $\begin{array}{l}\text { Total production (i } \\
\text { U.S dollars) }\end{array}$ & & & & & \\
\hline U.S. dollars) $1 /$ & 70.6 & I24.8 & 127.3 & 141.0 & 155.7 \\
\hline
\end{tabular}

Source: Ministry of Plan and Finance.

1/ Metical-dollar conversion made at official annual average rates up to 1995/96; market exchange rates used thereafter. 
Table 16. Mozambique: Commercialized Crop Production by the Family Sector, 1994/95-1998/99

(As a percentage of total marketed production)

\begin{tabular}{|c|c|c|c|c|c|}
\hline & $1994 / 95$ & $1995 / 96$ & $1996 / 97$ & $1997 / 98$ & 1998/99 \\
\hline \multicolumn{6}{|l|}{ Export crops } \\
\hline Cotton & 66.0 & 68.9 & 78.9 & 83.8 & 78.3 \\
\hline Copra & 67.9 & 59.8 & 50.0 & 50.0 & 50.0 \\
\hline Cashew nuts & 100.0 & 100.0 & 100.0 & 100.0 & 100.0 \\
\hline Citrus & 2.3 & 3.5 & 2.8 & 2.8 & 2.8 \\
\hline \multicolumn{6}{|l|}{ Basic food crops } \\
\hline Maize & 79.2 & 83.4 & 82.2 & 85.4 & 85.9 \\
\hline Rice & 49.6 & 59.2 & 60.3 & 58.6 & 58.4 \\
\hline Sorghum & 73.4 & 82.9 & 85.4 & 84.7 & 88.7 \\
\hline Cassava & 65.5 & 64.6 & 72.5 & 72.8 & 75.5 \\
\hline Peanuts & 95.6 & 97.2 & 96.4 & 96.2 & 96.4 \\
\hline Beans & 86.0 & 76.4 & 66.3 & 72.7 & 77.2 \\
\hline Vegetables & 19.7 & 24.0 & 47.0 & 46.6 & 47.1 \\
\hline Onions & 17.2 & 16.7 & 17.6 & 17.6 & 17.6 \\
\hline \multicolumn{6}{|l|}{ Industrial inputs } \\
\hline Mafurra & 100.0 & 100.0 & 100.0 & 100.0 & 100.0 \\
\hline Sunflowers & 0.9 & 11.9 & 25.0 & 25.9 & 29.8 \\
\hline
\end{tabular}

Source: Ministry of Plan and Finance. 
Table 17. Mozambique: Prices of Major Marketed Crops, 1994/95-1998/99

\begin{tabular}{|c|c|c|c|c|c|}
\hline & $1994 / 95$ & $1995 / 96$ & $1996 / 97$ & $1997 / 98$ & $1998 / 99$ \\
\hline & \multicolumn{5}{|c|}{ (In thousands of meticais per ton) } \\
\hline \multicolumn{6}{|l|}{ Export crops } \\
\hline Cotton & 1,350 & 3,850 & 3,260 & 3,390 & 3,203 \\
\hline Copra & 800 & 1,750 & 1,930 & 1,930 & 1,702 \\
\hline Tea (leaf) & 61 & 85 & 100 & 100 & 92 \\
\hline Sugar & 104 & 140 & 150 & 150 & 147 \\
\hline Cashew ruts & 1,000 & 3,500 & 4,000 & 4,400 & 4,404 \\
\hline \multicolumn{6}{|l|}{ Basic food crops } \\
\hline Maize & 850 & 1,460 & 1,200 & 1,310 & 1,502 \\
\hline Rice & 1,250 & 1,960 & 3,920 & 3,936 & 2,503 \\
\hline Sorghum & 748 & 1,940 & 2,140 & 2,140 & 2,142 \\
\hline Cassava & 1,033 & 670 & 790 & 901 & 1,447 \\
\hline Peanuts & 2,400 & 3,700 & 4,030 & 4,030 & 4,505 \\
\hline Citrus & 1,722 & 2,410 & 2,570 & 2,732 & 2,735 \\
\hline Beans & 2,100 & 4,080 & 3,300 & 3,300 & 3,303 \\
\hline Vegetables & 1,722 & 2,093 & 2,093 & 2,315 & 2,095 \\
\hline Onions & 2,754 & 4,110 & 4,400 & 3,749 & 3,603 \\
\hline \multicolumn{6}{|l|}{ Other crops } \\
\hline Sisal & 33 & 46 & 46 & 46 & 46 \\
\hline Tobacco & 7,533 & 12,125 & 13,167 & 13,693 & 13,180 \\
\hline Mafurra & 320 & 448 & 475 & 475 & 484 \\
\hline Tomatoes & 2,754 & 3,470 & 3,678 & 3,027 & 3,752 \\
\hline Sunflower & 110 & 2,600 & 2,600 & 2,704 & 2,603 \\
\hline & \multicolumn{5}{|c|}{ (Annual percentage changes) } \\
\hline \multicolumn{6}{|l|}{ Export crops } \\
\hline Cotton & 40.2 & 185.2 & -15.3 & 4.0 & -5.5 \\
\hline Copra & 60.0 & 118.8 & 10.3 & 0.0 & -11.8 \\
\hline Tea (leaf) & 10.9 & 39.3 & 17.6 & 0.0 & -8.0 \\
\hline Sugar & 50.7 & 34.6 & 7.1 & 0.0 & -2.0 \\
\hline Cashew nuts & 34.6 & 250.0 & 14.3 & 10.0 & 0.1 \\
\hline \multicolumn{6}{|l|}{ Basic food crops } \\
\hline Maize & 54.5 & 71.8 & -17.8 & 9.2 & 14.7 \\
\hline Rice & 25.0 & 56.8 & 100.0 & 0.4 & -36.4 \\
\hline Sorghum & 49.9 & 159.4 & 10.3 & 0.0 & 0.1 \\
\hline Cassava & 49.9 & -35.1 & 17.9 & 14.1 & 60.6 \\
\hline Peanuts & 60.0 & 54.2 & 8.9 & 0.0 & 11.8 \\
\hline Citrus & 50.0 & 40.0 & 6.6 & 6.3 & 0.1 \\
\hline Beans & 55.6 & 94.3 & -19.1 & 0.0 & 0.1 \\
\hline Vegetables & 50.0 & 21.5 & 0.0 & 10.6 & -9.5 \\
\hline Onions & 50.0 & 49.2 & 7.1 & -14.8 & -3.9 \\
\hline \multicolumn{6}{|l|}{ Other crops } \\
\hline Sisal & 43.5 & 39.4 & 0.0 & 0.0 & 0.0 \\
\hline Tobacco & 22.8 & 61.0 & 8.6 & 4.0 & -3.7 \\
\hline Mafurra & 33.3 & 40.0 & 6.0 & 0.0 & 1.9 \\
\hline Tomatoes & 50.0 & 26.0 & 6.0 & -17.7 & 24.0 \\
\hline Sunflower & -84.3 & $2,263.6$ & 0.0 & 4.0 & -3.7 \\
\hline \multicolumn{6}{|l|}{ Memorandum items: } \\
\hline Private consumption prices & 53.8 & 42.3 & 11.2 & 0.2 & 1.0 \\
\hline Exchange rate (MtUS\$) & 50.2 & 27.0 & 2.2 & 2.6 & 7.6 \\
\hline
\end{tabular}

Sources: Ministry of Agriculture; and Ministry of Plan and Finance. 
Table 18. Mozambique: Marketed Livestock, 1995-99 (In units stated)

\begin{tabular}{|c|c|c|c|c|c|}
\hline & 1995 & 1996 & 1997 & 1998 & 1999 \\
\hline \multicolumn{6}{|l|}{ Production volume } \\
\hline Beef (in tons) & 845 & 900 & 882 & 1,140 & 1,050 \\
\hline Pork (in tons) & 285 & 220 & 281 & 296 & 385 \\
\hline Chicken (in tons) & 3,700 & 3,700 & 5,109 & 4,579 & 5,417 \\
\hline Eggs (in thousands) & 6,044 & 2,900 & 6,982 & 4,945 & 5,440 \\
\hline Milk (in thousands of liters) & 920 & 650 & 821 & 742 & 915 \\
\hline \multicolumn{6}{|c|}{ Production value (in millions of meticais) } \\
\hline Beef & 7,503 & 11,188 & 12,608 & 17,927 & 17,501 \\
\hline Pork & 2,531 & 2,735 & 4,017 & 4,655 & 6,414 \\
\hline Chicken & 29,724 & 41,614 & 66,080 & 65,190 & 81,697 \\
\hline Eggs & 2,427 & 1,631 & 4,515 & 3,516 & 4,100 \\
\hline Milk & 1,750 & 1,731 & 2,515 & 2,501 & 3,268 \\
\hline Total & 43,935 & 58,899 & 89,735 & 93,789 & 112,980 \\
\hline \multicolumn{6}{|l|}{ Average prices } \\
\hline Beef $1 /$ & 8,879 & 12,431 & 14,295 & 15,725 & 16,668 \\
\hline Pork 1/ & 8,881 & 12,432 & 14,295 & 15,726 & 16,660 \\
\hline Chicken 1/ & 8,034 & 11,247 & 12,934 & 14,237 & 15,082 \\
\hline Eggs 2/ & 402 & 562 & 647 & 711 & 754 \\
\hline Milk 3/ & 1,902 & 2,663 & 3,063 & 3,371 & 3,572 \\
\hline
\end{tabular}

Sources: Ministry of Agriculture; and Ministry of Plan and Finance.

1/ Meticais per kilogram.

2/ Meticais per unit.

3/ Meticais per liter. 
Table 19. Mozambique: Industrial Production by Branch, 1995-99

\begin{tabular}{|c|c|c|c|c|c|}
\hline & 1995 & 1996 & 1997 & 1998 & 1999 \\
\hline & \multicolumn{5}{|c|}{ (Current prices, in billions of meticais) } \\
\hline Industry and fisheries & $3,274,166$ & $5,145,229$ & $\cdots$ & $\ldots$ & $\ldots$ \\
\hline Fisheries & 964,863 & $1,433,122$ & $\ldots$ & $\ldots$ & $\ldots$ \\
\hline Mining & 60,412 & 78,707 & $\ldots$ & $\ldots$ & ... \\
\hline Manufacturing & $2,059,608$ & $3,386,184$ & $4,669,000$ & $4,598,576$ & $4,584,352$ \\
\hline Food processing & 573,660 & 858,178 & $1,100,000$ & $1,029,377$ & $1,189,610$ \\
\hline \multicolumn{6}{|l|}{ Processed animal feed, } \\
\hline tea, and cashew nuts & 45,110 & 215,246 & 164,000 & 130,000 & $\ldots$ \\
\hline Beverages & 348,064 & 641,870 & 857,000 & $1,133,889$ & $1,604,142$ \\
\hline Tobacco & 47,807 & 90,828 & 118,000 & 124,978 & 134,269 \\
\hline Textiles & 207,353 & 342,904 & 589,000 & 151,299 & 403,876 \\
\hline Clothing & 76,305 & 92,678 & 200,000 & 219,910 & 236,873 \\
\hline Leather and furs & 132 & $\ldots$ & $\ldots$ & $\ldots$ & $\cdots$ \\
\hline Footwear & 2,352 & 3,370 & 1,000 & 4,330 & 5,834 \\
\hline Wood and cork & 170,708 & 222,316 & 231,000 & 258,000 & $\ldots$ \\
\hline Furniture & 3,700 & 6,372 & 7,000 & 4,692 & $\ldots$ \\
\hline Paper & 26,881 & 32,562 & 317,000 & 379,860 & 402,239 \\
\hline Chemical products & 33,562 & 41,661 & 44,000 & 46,633 & 35,303 \\
\hline Other chemicals & 81,717 & 161,296 & 197,000 & 210,847 & 224,230 \\
\hline Oil refineries & 14,824 & 20,133 & 27,000 & 29,000 & $\ldots$ \\
\hline Rubber & 87,826 & 150,243 & 168,000 & 143,035 & 72,425 \\
\hline Plastics & 11,735 & 34,543 & 55,000 & 69,093 & 124,450 \\
\hline Glass & 6,822 & 2,824 & 2,000 & 24,125 & 24,193 \\
\hline Other nonmetallic mineral products & 140,193 & 285,224 & 340,000 & 417,000 & $\ldots$ \\
\hline Metalworking (iron and steel) & 52,763 & 37,231 & 16,000 & 31,715 & 7,578 \\
\hline Metalworking (noniron) & 5,621 & 6,929 & 6,000 & 3,168 & 4,734 \\
\hline Metallurgy (except machinery) & 32,293 & 16,619 & 163,000 & 85,161 & 66,343 \\
\hline Nonelectrical machinery & 12,069 & 2,654 & 7,000 & 7,095 & 5,117 \\
\hline Appliances and electrical machinery & 20,627 & 27,779 & 23,000 & 31,022 & 31,073 \\
\hline Transport machinery & 52,849 & 86,115 & 29,000 & 58,211 & 7,911 \\
\hline $\begin{array}{l}\text { Tools and instruments (professional, } \\
\text { scientific, photography and optical) }\end{array}$ & 192 & $\ldots$ & $\ldots$ & $\ldots$ & $\ldots$ \\
\hline Other manufacturing & 4,443 & 5,741 & 6,000 & 4,877 & 3,687 \\
\hline Electricity & 189,283 & 247,216 & $\ldots$ & $\ldots$ & $\ldots$ \\
\hline
\end{tabular}


Table 19. Mozambique: Industrial Production by Branch, 1995-99 (concluded)

\begin{tabular}{|c|c|c|c|c|c|}
\hline & 1995 & 1996 & 1997 & 1998 & 1999 \\
\hline & \multicolumn{5}{|c|}{ (Growth of volume, in percent) $1 /$} \\
\hline Industry and fisheries & 16.3 & 11.6 & $\cdots$ & $\cdots$ & $\ldots$ \\
\hline Fisheries & 1.0 & 7.1 & $\cdots$ & $\cdots$ & $\ldots$ \\
\hline Mining & 6.4 & -28.7 & -28.7 & -28.7 & $\cdots$ \\
\hline Manufacturing & $\ldots$ & $\ldots$ & 37.8 & 321.5 & $\ldots$ \\
\hline Food processing & 11.8 & -4.4 & 37.8 & -2.4 & $\ldots$ \\
\hline Processed animal feed, & & & & & \\
\hline $\begin{array}{l}\text { tea, and cashew nuts } \\
\text { Beverages }\end{array}$ & $\begin{array}{r}350.0 \\
93,1\end{array}$ & $\begin{array}{r}252.6 \\
44.0\end{array}$ & $\begin{array}{r}253.6 \\
45.0\end{array}$ & $\begin{array}{r}254.6 \\
46.0\end{array}$ & $\cdots$ \\
\hline $\begin{array}{l}\text { Beverages } \\
\text { Tobacco }\end{array}$ & 14.0 & 60.7 & $\begin{array}{l}45.0 \\
61.7\end{array}$ & $\begin{array}{l}46.0 \\
62.7\end{array}$ & $\cdots$ \\
\hline Textiles & -16.7 & -0.8 & $\begin{array}{r}61.7 \\
0.2\end{array}$ & $\begin{array}{r}62.7 \\
1.2\end{array}$ & $\cdots$ \\
\hline Clothing & -28.0 & -51.2 & $\begin{array}{r}0.2 \\
-50.2\end{array}$ & 1.2 & $\cdots$ \\
\hline Leather and furs & $\ldots$ & $\ldots$ & $\begin{array}{r}-50.2 \\
34.7\end{array}$ & -49.2 & $\ldots$ \\
\hline $\begin{array}{l}\text { Leather and furs } \\
\text { Footwear }\end{array}$ & -62.4 & -15.8 & 34.7 & $\ldots$ & $\ldots$ \\
\hline $\begin{array}{l}\text { Footwear } \\
\text { Wood and cork }\end{array}$ & 10.5 & 3.9 & -77.8 & -13.8 & $\ldots$ \\
\hline $\begin{array}{l}\text { Wood and cork } \\
\text { Furniture }\end{array}$ & 17.0 & 11.4 & 24.9 & 5.9 & $\cdots$ \\
\hline Paper & -10.6 & 25.4 & -7.7 & 13.4 & $\cdots$ \\
\hline Chernical products & 6.8 & 6.7 & $\ldots$ & 27.4 & $\ldots$ \\
\hline $\begin{array}{l}\text { Chemical products } \\
\text { Other chemicals }\end{array}$ & 19.3 & -3.0 & -2.5 & 8.7 & $\ldots$ \\
\hline $\begin{array}{l}\text { Other chemicals } \\
\text { Oil refineries }\end{array}$ & 6.6 & 71 & 8.4 & -1.0 & $\ldots$ \\
\hline $\begin{array}{l}\text { Onl retineries } \\
\text { Rubber }\end{array}$ & -14.3 & 27.5 & 23.7 & 9.1 & $\cdots$ \\
\hline $\begin{array}{l}\text { Kubber } \\
\text { Plastics }\end{array}$ & -22.5 & -1.6 & 15.5 & 29.5 & $\ldots$ \\
\hline $\begin{array}{l}\text { Plastics } \\
\text { Glass }\end{array}$ & -17.4 & -49.2 & 4.4 & 0.4 & $\ldots$ \\
\hline & 114.6 & 24.1 & -39.3 & -47.2 & $\cdots$ \\
\hline Metalworking (iron and steel) & 14.4 & $\begin{array}{r}24.1 \\
-41.0\end{array}$ & 13.4 & 26.1 & $\cdots$ \\
\hline Metalworking (noniron) & -19.7 & & -71.1 & -39.0 & $\ldots$ \\
\hline & -13.2 & $\begin{array}{r}10.6 \\
-36.3\end{array}$ & $\ldots$ & 12.6 & $\ldots$ \\
\hline Nonelectrical machinery & 93.9 & & 8.9 & -34.3 & $\cdots$ \\
\hline & -23.7 & $\begin{array}{r}-71.4 \\
163\end{array}$ & $\ldots$ & -69.4 & $\ldots$ \\
\hline $\begin{array}{l}\text { Appliances and electrical machinery } \\
\text { Transport machinery }\end{array}$ & 119.5 & $\begin{array}{l}16.3 \\
528\end{array}$ & -28.3 & 18.3 & $\ldots$ \\
\hline Tools and instruments (professional, & & 52.8 & -43.3 & 54.8 & $\ldots$ \\
\hline scientific, photography and optical) & -99.3 & $\ldots$ & $\ldots$ & $\ldots$ & $\ldots$ \\
\hline Other manufacturing & 178.9 & 5.1 & 18.4 & 7.1 & $\ldots$ \\
\hline Electricity & 6.8 & 20.3 & 24.8 & 22.3 & $\ldots$ \\
\hline
\end{tabular}

Source: Mozambican authorities.

1/ Volume growth rates based on growth of value at previous year's prices. 
Table 20. Mozambique: Transport and Communications Activity, 1995-99

(In units indicated)

\begin{tabular}{|c|c|c|c|c|c|}
\hline & 1995 & 1996 & 1997 & 1998 & 1999 \\
\hline \multicolumn{6}{|l|}{ Freight transport } \\
\hline \multicolumn{6}{|l|}{ Rail } \\
\hline In millions of ton-kilometers & 892.7 & 982.8 & 899.2 & 860.9 & 721.2 \\
\hline In billions of meticais & 366.0 & 541.5 & 630.1 & 584.2 & 532.8 \\
\hline Unit tariff $1 /$ & 410.0 & 551.0 & 700.7 & 678.6 & 738.8 \\
\hline \multicolumn{6}{|l|}{ Road } \\
\hline In millions of ton-kilometers & 76.1 & 128.7 & 160.9 & 175.1 & 233.5 \\
\hline In billions of meticais & 47.9 & 97.3 & 124.6 & 140.1 & 233.5 \\
\hline Unit tariff $1 /$ & 629.4 & 756.0 & 774.4 & 800.1 & $1,000.0$ \\
\hline \multicolumn{6}{|l|}{ Maritime } \\
\hline In millions of ton-kilometers & 83.3 & 65.8 & 118.4 & 113.1 & 201.0 \\
\hline In billions of meticais & 14.1 & 12.2 & 37.6 & 37.3 & 69.6 \\
\hline Unit tariff $1 /$ & 169.3 & 185.4 & 317.6 & 329.8 & 346.3 \\
\hline \multicolumn{6}{|l|}{ Air } \\
\hline In millions of ton-kilometers & 8.6 & 7.9 & 5.5 & 5.9 & 6.1 \\
\hline In billions of meticais & 32.1 & 30.5 & 22.8 & 24.8 & 26.9 \\
\hline Unit tariff $1 /$ & $3,732.6$ & $3,860.8$ & $4,145.5$ & $4,203.4$ & $4,409.8$ \\
\hline \multicolumn{6}{|l|}{ Port throughput } \\
\hline In thousands of shipping tons & $7,508.4$ & $8,404.7$ & $8,959.9$ & $7,606.0$ & $6,117.6$ \\
\hline In billions of meticais & 109.2 & 399.3 & 573.5 & 532.4 & 449.6 \\
\hline Unit tariff 2/ & 14.5 & 47.5 & 64.0 & 70.0 & 73.5 \\
\hline \multicolumn{6}{|l|}{ Oil pipeline throughput } \\
\hline In millions of ton-kilometers & 308.9 & 279.2 & 329.7 & 355.8 & 324.0 \\
\hline In billions of meticais & 186.4 & 230.6 & 222.4 & 244.5 & 226.8 \\
\hline Unit tariff $1 /$ & 603.4 & 825.9 & 674.6 & 687.2 & 700.0 \\
\hline Total freight receipts 3 / & 755.7 & $1,311.4$ & $1,6] 1,0$ & $1,563.3$ & $1,539.2$ \\
\hline \multicolumn{6}{|l|}{ Passenger transport } \\
\hline \multicolumn{6}{|l|}{ Rail } \\
\hline In millions of passenger-kilometers & 312,0 & 350.4 & 403.1 & 155.0 & 144.7 \\
\hline In billions of meticais & 37.8 & 44.8 & 39.8 & 20.0 & 18.4 \\
\hline Unit tariff 4/ & 121.2 & 127.9 & 98.7 & 129.0 & 127.2 \\
\hline \multicolumn{6}{|l|}{ Road } \\
\hline In millions of passenger-kilometers & $14,746.9$ & $17,575.7$ & $20,773.2$ & $25,625.5$ & $29,023.8$ \\
\hline In billions of meticais & 715.7 & 924.8 & $1,641.2$ & $1,993.0$ & $2,292.6$ \\
\hline Unit tariff $4 /$ & 48.5 & $\$ 2.6$ & 79.0 & 77.8 & 79.0 \\
\hline \multicolumn{6}{|l|}{ Air } \\
\hline In millions of passenger-kilometers & 384.0 & 362.2 & 291.7 & 311.7 & 329.8 \\
\hline In billions of meticais & 308.1 & 334.1 & 297.3 & 333.5 & 352.9 \\
\hline Unit tariff 4/ & 802.3 & 922.4 & $1,019.2$ & $1,069.9$ & $1,070.0$ \\
\hline \multicolumn{6}{|l|}{ Maritime } \\
\hline In millions of passenger-kilometers & 4.6 & 5.1 & 6.6 & 6.0 & 2.1 \\
\hline In billions of meticais & 2.3 & 2.6 & 4.5 & 4.2 & 1.5 \\
\hline Unit tariff 4/ & 500.0 & 509.8 & 681.8 & 700.0 & 714.3 \\
\hline Total passenger receipts & $1,063,9$ & $1,306.3$ & $1,982.8$ & $2,350.7$ & $2,665.4$ \\
\hline Communications receipts $\mathbf{3}$ / & 634.7 & 748.1 & 857.1 & 925.3 & 111.4 \\
\hline \multicolumn{6}{|l|}{ Total transport and communications } \\
\hline receipts $3 /$ & $2,454.3$ & $3,365.8$ & $4,450.9$ & $4,839.3$ & $4,316.0$ \\
\hline
\end{tabular}

Source: Mozambican authorities.

1/ Meticais per ton-kilometer.

2/ In millions of meticais per ton.

3/ In billions of meticais.

4/ Meticais per passenger-kilometer. 
Table 21. Mozambique: Maputo Monthly Consumer Price Index, December 1989-October 2000

\begin{tabular}{|c|c|c|c|c|c|c|}
\hline & & $\begin{array}{r}\text { Consumer } \\
\text { Price } \\
\text { Index (CPI) } 1 / \\
\text { (December } \\
1998=100)\end{array}$ & $\begin{array}{r}\text { Monthly } \\
\text { Percentage } \\
\text { Change }\end{array}$ & $\begin{array}{r}\text { Accurnul- } \\
\text { ated in } \\
\text { Year } \\
\text { (In percent) }\end{array}$ & $\begin{array}{r}\text { Annual } \\
\text { Percentage } \\
\text { Changes } 2 /\end{array}$ & $\begin{array}{r}\text { Annual } \\
\text { Percentage } \\
\text { Changes } \\
\text { (Period } \\
\text { average) 3/ } \\
\end{array}$ \\
\hline 1989 & Dec. & 7 & 0.8 & 28.4 & 28.4 & 42.1 \\
\hline $1990 \mathrm{I}$ & Dec. & 10 & 5.4 & 47.1 & 47.1 & 43.7 \\
\hline $1991 \mathrm{I}$ & Dec. & 14 & 2.5 & 35.2 & 35.2 & 33.3 \\
\hline $1992 \mathrm{I}$ & Dec. & 21 & 5.5 & 54.5 & 54.5 & 45.1 \\
\hline $1993 \mathrm{I}$ & Dec. & 30 & 9.1 & 43.6 & 43.6 & 42.3 \\
\hline 1994 I & Dec. & 52 & 10.8 & 70.1 & 70.1 & 63.1 \\
\hline $1995 \mathrm{I}$ & Dec. & 81 & 9.1 & 57.0 & 57.0 & 53.1 \\
\hline $1996 \mathrm{D}$ & Dec. & 94 & 0.0 & 16.2 & 16.2 & 46.9 \\
\hline $1997 \mathrm{~J}$ & Jan. & 98 & 4.1 & 4.I & 16.3 & 5.4 \\
\hline & Feb. & 100 & 2.2 & 7.6 & 8.9 & 4.8 \\
\hline & Mar. & 100 & -0.2 & 6.9 & 6.4 & 4.4 \\
\hline & Apr. & 99 & -1.0 & 5.7 & 4.6 & 4.1 \\
\hline & May & 98 & -1.3 & 3.9 & 6.6 & 3.7 \\
\hline & June & 98 & 0.0 & 3.7 & 6.1 & 3.3 \\
\hline & July & 97 & -0.9 & 3.2 & 5.3 & 2.9 \\
\hline & August & 99 & 1.6 & 3.0 & 4.9 & 2.4 \\
\hline & Sep. & 98 & -0.4 & 2.4 & 4.2 & 2.0 \\
\hline & Oct. & 99 & 0.6 & 2.8 & 4.4 & 1.6 \\
\hline & Nov. & 100 & 0.8 & 4.1 & 4.1 & 1.1 \\
\hline & Dec. & 101 & 1.3 & 5.9 & 5.9 & 0.6 \\
\hline \multirow{12}{*}{1998} & Jan. & 102 & 1.4 & 1.4 & 4.2 & 5.4 \\
\hline & Feb. & 104 & 1.7 & 3.1 & 3.6 & 4.8 \\
\hline & March & 103 & -0.9 & 2.2 & 2.9 & 4.4 \\
\hline & April & 102 & -1.0 & 1.2 & 2.9 & 4.1 \\
\hline & May & 102 & -0.5 & 0.7 & 3.7 & 3.7 \\
\hline & June & 100 & -1.3 & -0.6 & 2.4 & 3.3 \\
\hline & July & 99 & -1.3 & -1.9 & 2.0 & 2.9 \\
\hline & August & 99 & -0.3 & -2.2 & 0.1 & 2.4 \\
\hline & Sep. & 98 & -0.8 & -3.0 & -0.3 & 2.0 \\
\hline & Oct. & 98 & -0.3 & -3.3 & -1.2 & 1.6 \\
\hline & Nov. & 99 & 1.2 & -2.1 & -0.8 & 1.1 \\
\hline & Dec. & 100 & 1.1 & -1.0 & -1.0 & 0.6 \\
\hline \multirow{12}{*}{1999} & Jan. & 103 & 2.7 & 1.7 & 0.3 & 1.2 \\
\hline & Feb. & 105 & 2.3 & 4.0 & 0.9 & 1.0 \\
\hline & March & 104 & -1.1 & 2.9 & 0.7 & 0.8 \\
\hline & April & 105 & 0.8 & 3.7 & 2.4 & 0.8 \\
\hline & May & 104 & -0.6 & 3.1 & 2.4 & 0.7 \\
\hline & June & 104 & -0.3 & 2.8 & 3.4 & 0.7 \\
\hline & July & 103 & -0.4 & 2.4 & 4.3 & 0.9 \\
\hline & August & 103 & -0.7 & 1.7 & 3.9 & 1,3 \\
\hline & Sep. & 102 & -0.3 & 1.4 & 4.5 & 1.6 \\
\hline & Oct. & 101 & -1.2 & 0.2 & 3.6 & 2.0 \\
\hline & Nov. & 101 & -0.3 & -0.1 & 2.0 & 2.3 \\
\hline & Dec. & 106 & 5.2 & 5.1 & 6.2 & 2.9 \\
\hline \multirow[t]{10}{*}{2000} & Jan. & 106 & -0.3 & 4.8 & 3.0 & 3.1 \\
\hline & Feb. & 114 & 7.6 & 12.8 & 8.5 & 3.8 \\
\hline & March & 117 & 2.3 & 15.3 & 12.1 & 4.7 \\
\hline & April & 118 & 1.6 & 17.2 & 13.1 & 5.6 \\
\hline & May & 119 & 0.8 & 18.1 & 14.6 & 6.7 \\
\hline & June & 118 & -1.3 & 16.6 & 13.5 & 7.5 \\
\hline & July & 119 & 0.7 & 17.4 & 14.7 & 8.4 \\
\hline & August & 117 & -1.2 & 16.0 & 14.1 & 9.2 \\
\hline & Sep. & 118 & 0.7 & 16.8 & 15.2 & 10.1 \\
\hline & Oct. & 118 & 0.2 & 17.0 & 16.8 & 11.2 \\
\hline
\end{tabular}

1/ In February 2000, the National Statisties Institute (INE) began compiling a new CPI series with December 1998 as base period. The consumer price index (CPI) was rebased on weights stemming from the 1998 census. The new index was extended backward using the gowth rates of the previous CPI.

2/ Compared with same month one year earlier.

3/ Monthly average of the previous 12 months. 
Table 22. Mozambique: Major Consumer Price Index (CPI) Categories, December 1997-December 1999 1/

\begin{tabular}{|c|c|c|c|}
\hline & 1997 & 1998 & 1999 \\
\hline & \multicolumn{3}{|c|}{ (December $1998=100$ ) } \\
\hline Total CPI & 101 & 100 & 106 \\
\hline Foods, drinks, and tobacco & 103 & 100 & 102 \\
\hline Clothing & 99 & 100 & 99 \\
\hline Firewood and furniture & 101 & 100 & 126 \\
\hline Health & 97 & 100 & 97 \\
\hline Transportation and communication & 86 & 100 & 103 \\
\hline Education, recreation, and culture & 90 & 100 & 117 \\
\hline Other goods and services & 102 & 100 & 104 \\
\hline Changes from previous period & \multicolumn{3}{|c|}{ (In percent) } \\
\hline Total CPI & $\ldots$ & -1.0 & 6.2 \\
\hline Foods, drinks, and tobacco & $\ldots$ & -2.6 & 1.7 \\
\hline Clothing & $\ldots$ & 1.2 & -0.6 \\
\hline Firewood and furniture & $\ldots$ & -1.1 & 25.8 \\
\hline Health & $\ldots$ & 2.7 & -3.2 \\
\hline Transportation and communication & $\ldots$ & 15.7 & 3.1 \\
\hline Education, recreation, and culture & $\cdots$ & 11.3 & 16.7 \\
\hline Other goods and services & $\ldots$ & -2.1 & 4.3 \\
\hline
\end{tabular}

Source: Mozambican authorities.

1/ In 2000, the consumer price index was rebased on weights stemming from the 1998 census (see footnote I in Table 21). 
Table 23. Mozambique: Minimum Agricultural Producer Prices 1/

$1995 / 96-1999 / 20002 /$

\begin{tabular}{|c|c|c|c|c|c|}
\hline & $1995 / 96$ & $1996 / 97$ & $1997 / 98$ & $1998 / 99$ & $1999 / 2000$ \\
\hline \multicolumn{6}{|l|}{ Cotton seed } \\
\hline Grade I & 3,900 & 3,300 & 2,950 & 2,300 & 2,500 \\
\hline Grade II & 3,000 & 3,100 & 2,600 & 1,950 & 2,100 \\
\hline Peanuts $3 /$ & 4,500 & $\mathrm{~N} / \mathrm{A}$ & N/A & N/A & N/A \\
\hline Whole rice $3 /$ & 2,500 & $\mathrm{~N} / \mathrm{A}$ & N/A & N/A & N/A \\
\hline Cashew nuts 4/ & 3,000 & 3,500 & $\mathrm{~N} / \mathrm{A}$ & $\mathrm{N} / \mathrm{A}$ & N/A \\
\hline Copra 4/ & 1,700 & 1,700 & $\mathrm{~N} / \mathrm{A}$ & N/A & N/A \\
\hline \multicolumn{6}{|l|}{ Beans 4/ } \\
\hline Type I & 4,000 & N/A & $\mathrm{N} / \mathrm{A}$ & N/A & $\mathrm{N} / \mathrm{A}$ \\
\hline Type II & 2,600 & N/A & $N / A$ & N/A & N/A \\
\hline White maize 3/ & 1,500 & $\mathrm{~N} / \mathrm{A}$ & $\mathrm{N} / \mathrm{A}$ & N/A & N/A \\
\hline Tobacco 3/4/ & 15,000 & 15,000 & N/A & N/A & N/A \\
\hline \multicolumn{6}{|l|}{ Cotton seed } \\
\hline Grade I & 160.0 & -15.4 & -10.6 & .22 .0 & 8.7 \\
\hline Grade II & 150.0 & 3.3 & -16.1 & -25.0 & 7.7 \\
\hline Peanuts & 87.5 & $\mathrm{~N} / \mathrm{A}$ & N/A & N/A & N/A \\
\hline Whole rice & 100.0 & N/A & N/A & N/A & $\mathrm{N} / \mathrm{A}$ \\
\hline Cashew nuts & 100.0 & 16.7 & $\mathrm{~N} / \mathrm{A}$ & $\mathrm{N} / \mathrm{A}$ & N/A \\
\hline Copra & 112.5 & 0.0 & N/A & $\mathrm{N} / \mathrm{A}$ & $\mathrm{N} / \mathrm{A}$ \\
\hline \multicolumn{6}{|l|}{ Beans } \\
\hline Type I & 60.0 & N/A & $\mathrm{N} / \mathrm{A}$ & N/A & N/A \\
\hline Type II & 52.9 & N/A & $\mathrm{N} / \mathrm{A}$ & N/A & N/A \\
\hline White maize & 57.9 & N/A & N/A & N/A & N/A \\
\hline Tobacco & 74.4 & 0.0 & $\mathrm{~N} / \mathrm{A}$ & N/A & N/A \\
\hline \multicolumn{6}{|l|}{ Memorandum items: } \\
\hline Private consumption deflator & 42.3 & 11.2 & 0.2 & 1.0 & $\ldots$ \\
\hline Exchange rate (Mt/US\$) & 27.0 & 2.2 & 2.6 & 7.6 & $\ldots$ \\
\hline
\end{tabular}

Source: Mozambican authorities.

1/ All minimum agricultural prices have become indicative prices since 1996.

2/ Prices are set in the fall before the planting season.

3/ Prices were liberalized in 1996.

4/ Prices were liberalized in 1997. 
Table 24. Mozambique: Administered Prices of Petroleum Products, 1995-99

\begin{tabular}{|c|c|c|c|c|c|c|c|c|c|c|c|c|c|c|c|c|c|c|c|}
\hline & $\begin{array}{l}1995 \\
\text { Feb. }\end{array}$ & $\begin{array}{l}1995 \\
\text { May }\end{array}$ & $\begin{array}{l}1995 \\
\text { Aug. }\end{array}$ & $\begin{array}{l}1996 \\
\text { Feb. }\end{array}$ & $\begin{array}{r}1996 \\
\text { April }\end{array}$ & $\begin{array}{l}1996 \\
\text { Aug. }\end{array}$ & $\begin{array}{l}1996 \\
\text { Nov }\end{array}$ & $\begin{array}{l}1997 \\
\text { Feb. }\end{array}$ & $\begin{array}{l}1997 \\
\text { April }\end{array}$ & $\begin{array}{l}1997 \\
\text { June }\end{array}$ & $\begin{array}{r}1997 \\
\text { July }\end{array}$ & $\begin{array}{l}1997 \\
\text { Oct. }\end{array}$ & $\begin{array}{r}1998 \\
\text { Jarn. }\end{array}$ & $\begin{array}{r}1998 \\
\text { March }\end{array}$ & $\begin{array}{r}1998 \\
\text { April }\end{array}$ & $\begin{array}{l}1998 \\
\text { Dec. }\end{array}$ & $\begin{array}{c}1999 \\
\text { Jan. }\end{array}$ & $\begin{array}{l}1999 \\
\text { Sept }\end{array}$ & $\begin{array}{r}1999 \\
\text { Oct. }\end{array}$ \\
\hline & \multicolumn{19}{|c|}{ (In meticais per liter, unless otherwise indicated) } \\
\hline Butạne (kg) & 3,909 & 4,363 & 5,363 & 6,368 & 6,364 & 6,545 & 6,545 & 6,546 & 6,633 & 6,638 & 6,651 & 6,765 & 6,513 & 6,662 & 6,615 & 6,664 & 5,652 & 7,018 & 7,204 \\
\hline Jet Al & 1,574 & 1,950 & 2,403 & 2,883 & 2,989 & 3,263 & 3,814 & 3,800 & 3,250 & 3,374 & 3,322 & 3,356 & 3,621 & 2,688 & 2,881 & 2,879 & 2,556 & 2,785 & 3,232 \\
\hline Kerosene & 1,620 & 1,820 & 2,260 & 2,690 & 2,790 & 2,910 & 3,580 & 3,540 & 2,850 & 2,980 & 2,910 & 2,920 & 3,170 & 2,250 & 2,450 & 2,444 & 2,120 & 2,350 & 2,350 \\
\hline Diesel & 1,860 & 2,270 & 2,860 & 3,500 & 4,180 & 4,560 & 5,640 & 5,550 & 4,980 & 5,150 & 5,110 & 5,240 & 6,180 & 4,750 & 4,750 & 4,440 & 4,340 & 4,340 & 4,340 \\
\hline Fuel oil l/ & 1,296 & 1,686 & 2,120 & 2,644 & 2,650 & 2,757 & 2,757 & 2,717 & 3,207 & 2,637 & 2,883 & 2,577 & 2,387 & 2,489 & 2,480 & 2,638 & 2,567 & 2,871 & 3,485 \\
\hline \multicolumn{20}{|l|}{ Memorandurn items: } \\
\hline \multicolumn{20}{|l|}{$\begin{array}{l}\text { Representative exchange rate (Mt/USs; } \\
\text { beginning of period) } 2\end{array}$} \\
\hline beginning of period) $2 /$ & 6,790 & 7,767 & 9,581 & 10,832 & 10,978 & 11,329 & 11,323 & 11,517 & 11,525 & 11,521 & 11,536 & 11,573 & 11,635 & 11,594 & 11,575 & 12,306 & 12,493 & 12,699 & 12.968 \\
\hline Prenium gasoline (US\$/U.S. gallon) & 2.0 & 2.0 & 2.0 & 2.0 & 2.0 & 2.2 & 2.2 & 2.2 & 2.2 & 2.2 & 2.2 & 2.3 & 2.2 & 2.1 & 2.1 & 2.0 & $\ldots$ & $\ldots$ & $\ldots$ \\
\hline Diesel (USS/U.S. gallon) & 1.0 & 1.1 & 1.1 & 1.2 & 1.4 & 1.5 & 1.9 & 1.8 & 1.6 & 1.7 & 1.7 & 1.7 & 2.0 & 1.6 & 1.6 & 1.4 & $\ldots$ & $\cdots$ & $\ldots$ \\
\hline \multicolumn{20}{|c|}{ Ratio of domestic to import price (in percent) } \\
\hline Premium gasoline & 4.3 & 4.3 & 3.8 & 3.9 & 4.0 & 3.6 & 3.6 & 3.4 & 3.6 & 3.6 & 3.8 & 3.9 & 2.4 & 2.3 & 2.3 & 2.3 & $\ldots$ & ... & $\ldots$ \\
\hline Diesel & 2.0 & 2.2 & 2.1 & 2.3 & 2.7 & 2.5 & 2.6 & 2.4 & 2.9 & 2.9 & 2.9 & 3.0 & 3.6 & 3.0 & 3.4 & 3.1 & $\ldots$ & $\cdots$ & ... \\
\hline & \multicolumn{19}{|c|}{ (Percentage changes) } \\
\hline Butane (kg) & 0.0 & 31.6 & 22.9 & 18.7 & -0.1 & 2.8 & 0.0 & 0.0 & 1.3 & 0.1 & 0.2 & 1.7 & -3.7 & -1.5 & -0.7 & 0.7 & -15.2 & 24.2 & 2.7 \\
\hline Jet $\mathrm{Al}$ & 21.5 & 23.9 & 23.2 & 20.0 & 3.7 & 9.2 & 16.9 & -0.4 & -14.5 & 3.8 & -1.5 & 1.0 & 7.9 & -19.9 & 7.2 & -0.1 & -11.2 & 9.0 & 16.0 \\
\hline Kerosene & 22.2 & 12.3 & 24.2 & 19.0 & 37 & 4.3 & 23.0 & -1.1 & -19.5 & 4.6 & -2.3 & 0.3 & 8.6 & .22 .9 & 8.9 & -0.2 & -13.1 & 10.8 & 0.0 \\
\hline Diesel & 9.4 & 22.0 & 26.0 & 22.4 & 19.4 & 9.1 & 23.7 & -1.6 & -10.3 & 3.4 & -0.8 & 2.5 & 17.9 & -9.4 & 0.0 & -6.5 & -2.3 & 0.0 & 0.0 \\
\hline Fuel oil $1 /$ & 42.4 & 30.1 & 25.7 & 24.7 & 0.2 & 4.0 & 0.0 & -1.4 & 18.0 & .17 .8 & 9.4 & -10.6 & .7 .4 & -3.4 & -0.4 & 6.4 & -1.2 & 10.1 & 21.4 \\
\hline \multirow{2}{*}{\multicolumn{20}{|c|}{$\begin{array}{l}\text { Memorandum items: } \\
\text { Representative exchange rate MutUSs: }\end{array}$}} \\
\hline \multicolumn{16}{|l|}{ Representative exchange rate (MATUSs: } & & & & \\
\hline beginning of period) $2 /$ & 5.2 & 14.4 & 23.4 & 13.1 & 1.3 & 3.2 & -0.1 & 0.4 & 0.1 & 0.0 & 0.1 & 0.3 & 0.9 & 0.2 & -0.5 & 6.1 & 7.9 & 3.2 & 3.8 \\
\hline Premium gasoline (USS/U.S. gallon) & 3.9 & 0.4 & 0.4 & 2.1 & 1.2 & 9.5 & 1.0 & .2 .1 & 1.3 & .0 .3 & -0.1 & 3.1 & -1.9 & -7.3 & -4.6 & -8.0 & $\ldots$ & $\ldots$ & .. \\
\hline Diesel (USS/U.S. gallon) & 4.0 & 6.7 & 2.1 & 8.2 & 17.8 & 5.7 & 23.7 & -3.3 & -10.3 & 3.4 & -0.9 & 2.2 & 19.9 & -9.5 & -22.7 & -11.9 & $\ldots$ & $\ldots$ & $\ldots$ \\
\hline
\end{tabular}

Source: Mozambican authorities.

1/ Wholesale price.

2/ Before January 1997, the representative exchange tate was the official rate; the market rate is used thereafter. 
Table 25. Mozambique: Import Prices of Oil Products, 1995-99

\begin{tabular}{|c|c|c|c|c|c|}
\hline Products & 1995 & 1996 & 1997 & 1998 & 1999 \\
\hline & \multicolumn{5}{|c|}{ (U.S. dollars per unit indicated) } \\
\hline Liquefied petroleum gas (butane) (ton) & 261.2 & 268.9 & 240.8 & 227.2 & 232.9 \\
\hline Aviation gasoline (cubic meter) & 305.2 & 291.9 & 178.8 & 266.3 & 266.6 \\
\hline Premium gasoline (cubic meter) & 133.7 & 159.4 & 157.1 & 116.9 & 186.8 \\
\hline Jet Al (cubic meter) & 188.4 & 189.4 & 190.4 & 107.6 & 163.0 \\
\hline Diesel (cubic meter) & 137.5 & 172.3 & 153.4 & 102.4 & 143.4 \\
\hline Fuel oil (cubic meter) & 123.8 & 124.8 & 125.8 & 82.2 & 105.3 \\
\hline Memorandum items: & \multicolumn{5}{|c|}{ (Ratio of import to international prices) $1 /$} \\
\hline Premium gasoline & 1.00 & 1.03 & 1.01 & 1.06 & 1.36 \\
\hline Jet fuel/kerosene & 1.39 & 1.11 & 1.23 & 1.00 & 1.18 \\
\hline Diesel & 1.07 & 1.06 & 1.04 & 1.01 & 1.14 \\
\hline Fuel oil & 1.33 & 1.22 & 1.37 & 1.28 & 1.16 \\
\hline
\end{tabular}

Sources: Petromoc; and International Energy Agency, International Energy Agency Monthly Oil Market Report, MIREME (Dir. Nacional de Energia).

1/ International prices refer to Rotterdam. 
Table 26. Mozambique: Price Structure of Petroleum Products, Fourth Quarter 1999

\begin{tabular}{|c|c|c|c|c|c|c|}
\hline & Butane l/ & $\begin{array}{l}\text { Premium } \\
\text { Gasoline }\end{array}$ & Jet $A l$ & Kerosene & Diesel & $\begin{array}{r}\text { Fuel } \\
\text { Oil } \\
\end{array}$ \\
\hline & \multicolumn{6}{|c|}{ (Meticais per liter) } \\
\hline Cost (c.i.f.) & $3,024.1$ & $1,771.0$ & $1,742.7$ & $1,313.0$ & $1,301.2$ & $1,831.1$ \\
\hline Customs charges & 132.9 & 81.7 & 80.2 & 58.8 & 58.2 & 84.1 \\
\hline Special fixed tax & 284.0 & $3,307.8$ & 430.2 & 0.0 & $1,605.0$ & 328.3 \\
\hline Importer/distributor's margin & $2,053.5$ & 737.7 & 737.7 & 737.7 & 737.7 & 737.7 \\
\hline Tax and surcharge & 860.9 & 440.4 & 0.0 & 0.0 & 355.5 & 452.2 \\
\hline Wholesale price, net & $6,355.4$ & $6,338.5$ & $2,990.9$ & $2,109.4$ & $4,058.5$ & $3,440.5$ \\
\hline Transport differential & 112.6 & 37.8 & 37.8 & 37.8 & 37.8 & 37.8 \\
\hline Wholesale price, gross & $6,487.2$ & $6,382.7$ & $3,028.6$ & $2,153.6$ & $4,102.7$ & $3,484.7$ \\
\hline Retailer's margin & 613.0 & 207.6 & 207.6 & 207.6 & 207.6 & 0.0 \\
\hline $\begin{array}{l}\text { Retail price, net } \\
\text { Tax (1 percent) }\end{array}$ & $2,275.9$ & $1,363.6$ & $1,780.6$ & $1,345.9$ & 977.7 & $1,423.8$ \\
\hline Calculated retail price, gross & $7,204.4$ & $6,620.0$ & $3,236.3$ & $2,350.0$ & $4,340.0$ & $3,484,7$ \\
\hline \multicolumn{7}{|l|}{ Memorandum items: } \\
\hline Total taxes & $2,262.0$ & $4,311.1$ & 510.4 & 58.8 & $2,417,0$ & $1,323.7$ \\
\hline Total margins & $2,666.5$ & 945.3 & 945.3 & 945.3 & 945.3 & 737.7 \\
\hline Retail price (in US\$/iter) $2 /$ & 55.6 & 51.0 & 25.0 & 18.1 & 33.5 & 26.9 \\
\hline & \multicolumn{6}{|c|}{ (In percent of retail price) } \\
\hline \multicolumn{7}{|l|}{ Import cost } \\
\hline Margins and taxes & 40.5 & 17.8 & 22.8 & 31.4 & 25.2 & 34.1 \\
\hline Wholesale price & 90.0 & 96.4 & 93.6 & 91.6 & 94.5 & 100.0 \\
\hline Retail price & 100.0 & 100.0 & 100.0 & 100.0 & 100.0 & 100.0 \\
\hline \multicolumn{7}{|l|}{ Memorandum items: } \\
\hline Total taxes & 31.4 & 65.1 & 15.8 & 2.5 & 55.7 & 38.0 \\
\hline Total margins & 37.0 & 0.1 & 0.3 & 0.4 & 0.2 & 0.2 \\
\hline Total taxes and margins & 0.7 & 0.8 & 0.4 & 0.4 & 0.8 & 0.6 \\
\hline
\end{tabular}

Source: Mozambican authorities.

1/ Meticais per kilogram.

2/ In the case of butane, U.S. dollars per kilogram. 
Table 27. Mozambique: Minimum Monthly Wage, 1995-2000 1/

\begin{tabular}{|c|c|c|c|c|c|c|c|}
\hline & 1995 & 1995 & 1996 & 1997 & 1998 & 1999 & 2000 \\
\hline & & Dec. & June & April & April & April & July \\
\hline \multicolumn{8}{|l|}{ Nominal monthly wage (in meticais) } \\
\hline Agricultaral worker & 105,600 & 145,200 & 180,000 & 209,960 & 238,873 & $\ldots$ & $\ldots$ \\
\hline Nonagricultural worker & 158,650 & 218,650 & 271,126 & 311,794 & 353,886 & 450,000 & 568,980 \\
\hline Technical/administrative worker & 158,650 & 218,650 & 271,126 & 311,794 & 353,886 & 400,000 & 568,980 \\
\hline \multicolumn{8}{|l|}{ Real wage index ( $\operatorname{Jan} 1991=100$ ) } \\
\hline Agricultural worker & 1,297 & 1,186 & 1,294 & 1,402 & 1,550 & $\cdots$ & $\cdots$ \\
\hline Nonagricultural worker & 1,461 & 1,339 & 1,462 & 1,561 & 1,722 & 2,137 & 2,386 \\
\hline Technical/administrative worker & 1,461 & 1,339 & 1,462 & 1,561 & 1,722 & 1,900 & 2,386 \\
\hline \multicolumn{8}{|l|}{ Norninal monthly wage (in U.S. dollars) } \\
\hline Agricultural worker & 16 & 13 & 16 & 18 & 21 & $\cdots$ & $\ldots$ \\
\hline Nonagricultural worker & 23 & 20 & 24 & 27 & 31 & 36 & 37 \\
\hline Technical/administrative worker & 23 & 20 & 24 & 27 & 31 & 32 & 37 \\
\hline \multicolumn{8}{|l|}{ Memorandum items: } \\
\hline Consumer price index (CPI) (Dec 1998 $=100)$ & 54 & 81 & 92 & 99 & 102 & 105 & 119 \\
\hline Exchange rate (Mt/US\$, end of period) & 6,792 & 10,776 & 11,363 & 11,609 & 11,530 & 12,424 & 15,400 \\
\hline \multicolumn{8}{|c|}{ (Peroentage change) } \\
\hline \multicolumn{8}{|l|}{ Nominal monthly wage (in meticais) } \\
\hline Agricultural worker & 20.0 & 37.5 & 24.0 & 16.6 & 13.8 & $\cdots$ & $\ldots$ \\
\hline Nonagricultural worker & 35.0 & 37.8 & 24.0 & 15.0 & 13.5 & 27.2 & 26.4 \\
\hline Tectnical/administrative worker & 35.0 & 37.8 & 24.0 & 15.0 & 13.5 & 13.0 & 42.2 \\
\hline \multicolumn{8}{|l|}{ Real wage index } \\
\hline Agricultural worker & 68.1 & -8.6 & 9.2 & 8.3 & 10.6 & $\cdots$ & $\ldots$ \\
\hline Nonagricultural worker & 89.1 & -8.4 & 9.2 & 6.8 & 10.3 & 24.1 & 11.6 \\
\hline Technical/administrative worker & 89.1 & -8.4 & 9.2 & 6.8 & 10.3 & 10.3 & 25.6 \\
\hline \multicolumn{8}{|l|}{ Nominal monthly wage (in U.S. dollars) } \\
\hline Agricultural worker & 3.9 & -13.3 & 17.6 & 14.2 & 14.6 & 24.1 & 11.6 \\
\hline Nonagricultural worker & 16.9 & -13.1 & 17.6 & 12.6 & 14.3 & 10.3 & 25.6 \\
\hline Teohnical/sdministrative worker & 16.9 & -13.1 & 17.6 & 12.6 & 14.3 & 4.9 & 14.8 \\
\hline \multicolumn{8}{|l|}{ Memorandum items: } \\
\hline CPI & -28.6 & 50.4 & 13.6 & 7.7 & 2.9 & 2.4 & 13.3 \\
\hline Exchange rate (meticais/US\$) & 15.5 & 58.7 & 5.4 & 2.2 & -0.7 & 7.8 & 24.0 \\
\hline
\end{tabular}

Source: Ministry of Labor.

1/ Months shown refer to time of change. 


$$
-85-
$$

Table 28. Mozambique: Expenditure on the Sooial Sectors, 1995-99

\begin{tabular}{|c|c|c|c|c|c|}
\hline & 1995 & 1996 & 1997 & 1998 & 1999 \\
\hline & \multicolumn{5}{|c|}{ (In billions of meticais) } \\
\hline Total social expenditure & 693 & 1,006 & 1,320 & 1,716 & 2,247 \\
\hline Current expenditure & 606 & 884 & 1,208 & 1,545 & 2,047 \\
\hline Salaries and wages 1/ & 346 & 524 & 706 & 942 & 1,377 \\
\hline Education & 252 & 379 & 509 & 688 & 1,031 \\
\hline Health & 73 & 114 & 156 & 203 & 269 \\
\hline Rural development & 21 & 31 & 41 & 51 & 76 \\
\hline Goods and services $1 /$ & 217 & 310 & 462 & 552 & 524 \\
\hline Education & 103 & 157 & 229 & 249 & 229 \\
\hline Health & 94 & 126 & 200 & 265 & 252 \\
\hline Rural development & 20 & 27 & 34 & 38 & 43 \\
\hline Price subsidies $2 /$ & 4 & 3 & 3 & 3 & 5 \\
\hline Social subsidies & 39 & 47 & 37 & 48 & 87 \\
\hline Inoome transfers $3 /$ & 3 & $\ldots$ & $\ldots$ & $\ldots$ & $\ldots$ \\
\hline Food supplements $3 /$ & 35 & $\ldots$ & $\cdots$ & $\ldots$ & $\ldots$ \\
\hline Other & 2 & $\ldots$ & $\ldots$ & $\ldots$ & $\ldots$ \\
\hline Capital expenditure 4 & 87 & 122 & 112 & $17 !$ & 200 \\
\hline Education & 52 & 71 & 63 & 96 & 139 \\
\hline Health & 35 & 51 & 49 & 76 & 61 \\
\hline \multicolumn{6}{|l|}{ Memorandurm items: } \\
\hline Current expenditure on education and health & 522 & 776 & 1,094 & 1,405 & 1,831 \\
\hline Education & 355 & 536 & 738 & 937 & 1,291 \\
\hline Health & 167 & 240 & 356 & 468 & 540 \\
\hline Total expenditure on education and health & 609 & 898 & 1,206 & 1,577 & 2,031 \\
\hline Eduoation & 407 & 607 & 801 & 1,033 & 1,430 \\
\hline Health & 202 & 291 & 405 & 544 & 601 \\
\hline Current expenditure & 2,188 & 3,077 & 4,272 & 5,173 & 6,357 \\
\hline \multirow[t]{2}{*}{ GDP (Mt billions) } & 54,537 & 32,719 & 40,554 & 46,427 & 50827.306 \\
\hline & \multicolumn{5}{|c|}{ (In percent of GDP) } \\
\hline Current expenditure on social sectors & 1.1 & 2.7 & 3.0 & 3.3 & 4.0 \\
\hline Education & 0.7 & 1.6 & 1.8 & 2.0 & 2.5 \\
\hline Health & 0.3 & 0.7 & 0.9 & 1.0 & 1.1 \\
\hline Rural development & 0.1 & 0.2 & 0.2 & 0.2 & 0.2 \\
\hline Price subsidieg & 0.0 & 0.0 & 0.0 & 0.0 & 0.0 \\
\hline Social subsidies & 0.1 & 0.1 & 0.1 & 0.1 & 0.2 \\
\hline Total expenditure on sooial sectors & 1.3 & 3.1 & 3.3 & 3.7 & 4.4 \\
\hline Education & 0.7 & 1,9 & 2.0 & 2.2 & 2.8 \\
\hline Health & 0.4 & 0.9 & 1.0 & 1.2 & 1.2 \\
\hline Rural development & 0.1 & 0.2 & 0.2 & 0.2 & 0.2 \\
\hline Price subsidies & 0.0 & 0.0 & 0.0 & 0.0 & 0.0 \\
\hline \multirow[t]{2}{*}{ Social subsidies } & 0.1 & 0.1 & 0.1 & 0.1 & 0.2 \\
\hline & \multicolumn{5}{|c|}{ (In percent of current expenditure) } \\
\hline Current expenditure on social sectors & 27.7 & 28.7 & 28.3 & 29.9 & 32.2 \\
\hline Education & 16.2 & 17.4 & 17.3 & 18.1 & 20.3 \\
\hline Health & 7.6 & 7.8 & 8.3 & 9.0 & 8.5 \\
\hline Rural development & 1.9 & 1.9 & 1.8 & 1.7 & 1.9 \\
\hline Price subsidies & 0.2 & 0.1 & 0.1 & 0.1 & 0.1 \\
\hline Sacial subsidies & 1.8 & 1.5 & 0.9 & 0.9 & 1.4 \\
\hline
\end{tabular}

Source: Ministry of Plan and Finance

1/ Salaries and wages correspond to the budget entry "salaries and wages" for the corresponding sectors.

The same holds for goods and services.

2/ Buss transport subsidies to school children and senior citizens.

3/ Both income transfers and food supplements are paid in cash, but different oriteria are used in their allocation.

4/ Locally financed expenditure only. 
Table 29. Mozambique: Number of Households Receiving Food Subsidy Assistance,

March 1996-December 1999

\begin{tabular}{|c|c|c|c|c|c|c|c|c|c|c|c|c|c|c|c|c|}
\hline & \multicolumn{4}{|c|}{1996} & \multicolumn{4}{|c|}{1997} & \multicolumn{4}{|c|}{1998} & \multicolumn{4}{|c|}{1999} \\
\hline & March & June & Sep. & Dec. & March & June & Sep. & Dec. & March & June & Sep. & Dec. & March & June & Sep. & Dec. \\
\hline Total households & 84,404 & 89,811 & 92,064 & 92,064 & 37,460 & 38,773 & 39,893 & 39,893 & 30,693 & 31,027 & 33,348 & 35,974 & 38,656 & 38,656 & 39,051 & 39,051 \\
\hline \multicolumn{17}{|l|}{ Eligible on account of } \\
\hline $\begin{array}{l}\text { Malnourished children } 1 / \\
\text { Underweight pregnant }\end{array}$ & 32,478 & 34,933 & 34,985 & 34,985 & 3,565 & 4,648 & 5,125 & 5,125 & 3,056 & 2,889 & 3,523 & 3,830 & 2,320 & 2,320 & 2,218 & 2,218 \\
\hline women $2 /$ & 5,961 & 6,171 & 6,221 & 6,221 & 826 & 826 & 788 & 788 & 395 & 312 & 301 & 367 & 1,546 & 1,546 & 1,533 & 1,533 \\
\hline Destitute elderly $3 /$ & 41,051 & 43,265 & 45,088 & 45,088 & 29,587 & 29,587 & 29,182 & 29,182 & 23,791 & 24,295 & 25,479 & 27,412 & 31,312 & 31,312 & 31,486 & 31.486 \\
\hline Handicapped 4/ & 3,297 & 3,372 & 3,432 & 3,432 & 2,368 & 2,368 & 3,221 & 3,221 & 2,143 & 2,173 & 2,561 & 2,629 & 773 & 772 & 2,566 & 2,566 \\
\hline Unspecified $5 /$ & 1,617 & 2,070 & 2,338 & 2,338 & 1,114 & 1,344 & 1,577 & 1,577 & 1,308 & 1,358 & 1,484 & 1,736 & 2,705 & 2,705 & 2,781 & 2,781 \\
\hline
\end{tabular}

Source: Ministry of Plan and Finance, Office for Vulnerable Population Initiatives (GAPVU)

1/ Malnourished children up to 5 years of age.

2) Pregnant women who are underweight relative to their gestation period.

3/ Elderly people without means of subsistence living alone or in households with no wage earners.

4/ Seriously handicapped people over 18 years old living in poverty and without physical capacities to make a living

5/ Households headed by women with more than five children, and chronically ill persons. 
Table 30. Mozambique: Budget Subsidies to Enterprises, 1995-99

(In millions of meticais, unless otherwise specified)

\begin{tabular}{|c|c|c|c|c|c|c|c|c|c|c|}
\hline & \multicolumn{2}{|c|}{1995} & \multicolumn{2}{|c|}{1996} & \multicolumn{2}{|c|}{1997} & \multicolumn{2}{|c|}{1998} & \multicolumn{2}{|c|}{1999} \\
\hline & Outturn & $\begin{array}{l}\text { In percent } \\
\text { of total }\end{array}$ & Outturn & $\begin{array}{l}\text { In percent } \\
\text { of total }\end{array}$ & Est. & $\begin{array}{l}\text { In percent } \\
\text { of total }\end{array}$ & Est. & $\begin{array}{l}\text { In percent } \\
\text { of total }\end{array}$ & Est. & $\begin{array}{l}\text { In percent } \\
\text { of total }\end{array}$ \\
\hline Agriculture & 8,600 & 29.7 & 6,531 & 21.1 & 11,521 & 29.5 & 6,000 & 12.2 & 7,300 & 15.2 \\
\hline Sugar & 3,000 & 10.4 & 1,700 & 5.5 & 7,616 & 19.5 & 0 & 0.0 & 0 & 0.0 \\
\hline Tea and copra & 1,500 & 5.2 & 3,250 & 10.5 & 1,000 & 2.6 & 0 & 0.0 & 0 & 0.0 \\
\hline Other enterprises & 4,100 & 14.2 & 1,581 & 5.1 & 2,905 & 7.4 & 6,000 & 12.2 & 7,300 & 15.2 \\
\hline Mineral resources & 2,343 & 8.1 & 2,100 & 6.8 & 2,000 & 5.1 & 7,000 & 14.3 & 1,500 & 3.1 \\
\hline Coal (Carbomoc) & 2,343 & 8.1 & 2,000 & 6.5 & 2,000 & 5.1 & 7,000 & 14.3 & 1,500 & 3.1 \\
\hline Other minerals & 0 & 0.0 & 100 & 0.3 & 0 & 0.0 & 0 & 0.0 & 0 & 0.0 \\
\hline Other industries & 18,012 & 62.2 & 22,369 & 72.2 & 25,500 & 65.4 & 36,000 & 73.5 & 39,100 & 81.6 \\
\hline Electricity (EDM) & 0 & 0.0 & 0 & 0.0 & 0 & 0.0 & 0 & 0.0 & 0 & 0.0 \\
\hline Construction material & 0 & 0.0 & 0 & 0.0 & 0 & 0.0 & 0 & 0.0 & 0 & 0.0 \\
\hline Other enterprises & 4,200 & 14.5 & 2,000 & 6.5 & 3,000 & 7.7 & 7,500 & 15.3 & 4,800 & 10.0 \\
\hline Information services & 13,812 & 47.7 & 20,369 & 65.7 & 22,500 & 57.7 & 28,500 & 58.2 & 34,300 & 71.6 \\
\hline Total subsidies & 28,957 & 100.0 & 31,000 & 100.0 & 39,021 & 100.0 & 49,000 & 100.0 & 47,900 & 100.0 \\
\hline
\end{tabular}

Source: Ministry of Plan and Finance. 
Table 31. Mozambique: Government Finances, 1997-99 1/

\begin{tabular}{|c|c|c|c|}
\hline & 1997 & 1998 & 1999 \\
\hline & \multicolumn{3}{|c|}{ (In billions of meticais) } \\
\hline Total revenue & 4,623 & 5,324 & 6,207 \\
\hline Tax revenue & 4,235 & 4,932 & 5,733 \\
\hline Taxes on income and profits & 879 & 963 & 867 \\
\hline Taxes on goods and services & 2,389 & 2,882 & 3,638 \\
\hline Taxes on international trade & 812 & 937 & 1,046 \\
\hline Other taxes & 155 & 150 & 183 \\
\hline Nontax revenue & 388 & 392 & 474 \\
\hline Total expenditure and net lending & 9,498 & 10,141 & 12,815 \\
\hline Current expenditure & 4,272 & 5,268 & 6,332 \\
\hline Budget year & 4,361 & 5,259 & 6,347 \\
\hline Compensation to employees & 1,445 & 2,097 & 2,995 \\
\hline Wages and salaries & $\ldots$ & 1,873 & 2,806 \\
\hline Other & $\ldots$ & 224 & 189 \\
\hline Goods and services & 1,334 & 1,544 & 1,646 \\
\hline Interest on public debt & 530 & 463 & 324 \\
\hline Domestic & 34 & 21 & 6 \\
\hline Extemal & 496 & 442 & 318 \\
\hline Transfer payments & 750 & 874 & 1,085 \\
\hline Local and district governments & 80 & 102 & 105.2 \\
\hline Political parties & 51 & 57 & 66 \\
\hline Households & 420 & 463 & 646 \\
\hline Pensions & 354 & 390 & 559 \\
\hline Welfare payments & 48 & 37 & 87 \\
\hline Other & 18 & 36 & 0 \\
\hline Subsidies to enterprises & 47 & 46 & 54 \\
\hline Abroad & 152 & 206 & 214 \\
\hline Embassies & 132 & 182 & 214 \\
\hline International organisations & 20 & 24 & 0 \\
\hline Other & 302 & 281 & 297 \\
\hline Net float & -89 & 9 & -15 \\
\hline Current balance & 351 & 56 & .125 \\
\hline Capital expenditure & 4,816 & 4,575 & 6,001 \\
\hline Budget year & 3,754 & 4,843 & 5,734 \\
\hline External project grants & 1,562 & 2,091 & 2,710 \\
\hline External project loans & 1,435 & 1,673 & 1,306 \\
\hline Locally-financed & 742 & 1,079 & 1,717 \\
\hline Donor-financed outside budget & 15 & 0 & 0 \\
\hline HIPC & & 0 & 0 \\
\hline Net float & 1,062 & -268 & 267 \\
\hline Net lending & 410 & 298 & 482 \\
\hline Unallocated revenue $(+)$ /expenditure $(-)$ & 139 & -106 & -220 \\
\hline
\end{tabular}


Table 31. Mozambique: Government Finances, 1997-99 (continued) 1/

$1997 \quad 1998 \quad 1999$

(In billions of meticais)

Overall balance before grants

$-4,736 \quad-4,923 \quad-6,828$

Grants received

$3,705 \quad 3,818 \quad 6,035$

Project

Nonproject

$1,962 \quad 1,894 \quad 2,748$

Overall balance after grants

$1,743 \quad 1,924 \quad 3,287$

External borrowing (net)

$-1,031 \quad-1,105 \quad-793$

Disbursements

$2,329 \quad 2,172 \quad 910$

Project

$2,752 \quad 2,671 \quad 1,394$

Nonproject

$1,897 \quad 1,641 \quad 1,394$

Cash amortization

$855 \quad 1,030 \quad 0$

Domestic financing (net)

Banking system

Other (including residual)

$-1,298 \quad-1,067 \quad-117$

$\begin{array}{lll}-1,298 & -1,067 & -177\end{array}$

$0 \quad 0 \quad 60$

Memorandum items:

Primary current balance $2 /$

$\begin{array}{lll}881 & 519 & 199\end{array}$

Domestic primary balance before grants $3 /$

\begin{tabular}{lll}
291 & -289 & $-1,780$ \\
\hline
\end{tabular}

Sources: Mozambican authorities; and staff estimates.

1/ The presentation of the fiscal accounts has been revised as of 1997. The linkage to the old presentation was reported in the last year Statistical Annex (SM/99/143). Historical data have not been revised to reflect the new presentation.

2/ Current revenue minus noninterest current expenditure.

3/ Total revenue minus noninterest current expenditure minus locally financed capital expenditure and locally financed net lending. 
Table 32. Mozambique: Govemuent Finances, 1997-99

\begin{tabular}{|c|c|c|c|}
\hline & 1997 & 1998 & 1999 \\
\hline & \multicolumn{3}{|c|}{ (in percent of GDP) } \\
\hline Total revenue & 11.4 & 11.5 & 12.2 \\
\hline Tax revenue & 10.4 & 10.6 & 11.3 \\
\hline Taxes on income and profits & 2.2 & 2.1 & 1.7 \\
\hline Taxes on goods and services & 5.9 & 6.2 & 7.2 \\
\hline Taxes on international trade & 2.0 & 2.0 & 2.1 \\
\hline Other taxes & 0.4 & 0.3 & 0.4 \\
\hline Nontax revenue & 1.0 & 0.8 & 0.9 \\
\hline Total expenditure and net lending & 23.4 & 21.8 & 25.2 \\
\hline Current expenditure & 10.5 & 11.3 & 12.5 \\
\hline Budget year & 10.8 & 11.3 & 12.5 \\
\hline Compensation to employees & 3.6 & 4.5 & 5.9 \\
\hline Goods and services & 3.3 & 3.3 & 3.2 \\
\hline Interest on public debt & 1.3 & 1.0 & 0.6 \\
\hline Domestic & 0.1 & 0.0 & 0.0 \\
\hline External & 1.2 & 1.0 & 0.6 \\
\hline Transfer payments & 1.8 & 1.9 & 2.1 \\
\hline Local and district governments & 0.2 & 0.2 & 0.2 \\
\hline Political parties & 0.1 & 0.1 & 0.1 \\
\hline Households & 1.0 & 1.0 & 1.3 \\
\hline Pensions & 0.9 & 0.8 & 1.1 \\
\hline Welfare payments & 0.1 & 0.1 & 0.2 \\
\hline Other & 0.0 & 0.1 & 0.0 \\
\hline Subsidies to enterprises & 0.1 & 0.1 & 0.1 \\
\hline Abroad & 0.4 & 0.4 & 0.4 \\
\hline Embassies & 0.3 & 0.4 & 0.4 \\
\hline International organisations & 0.0 & 0.1 & 0.0 \\
\hline Other & 0.7 & 0.6 & 0.6 \\
\hline Net float & -0.2 & 0.0 & 0.0 \\
\hline Current balance & 0.9 & 0.1 & -0.2 \\
\hline Capital expenditure & 11.9 & 9.9 & 11.8 \\
\hline Budget year & 9.3 & 10.4 & 11.3 \\
\hline External project grants & 3.9 & 4.5 & 5.3 \\
\hline Extemal project loans & 3.5 & 3.6 & 2.6 \\
\hline Locally financed & 1.8 & 2.3 & 3.4 \\
\hline Danor-financed outside budget & 0.0 & 0.0 & 0.0 \\
\hline HIFC & 0.0 & 0.0 & 0.0 \\
\hline Net float & 2.6 & -0.6 & 0.5 \\
\hline Net lending & 1.0 & 0.6 & 0.9 \\
\hline Unallocated revenue $(+y$ expenditure $(-)$ & 0.3 & -0.2 & -0.4 \\
\hline Overall balance before grants & -11.7 & -10.6 & -13.4 \\
\hline Grants received & 9.1 & 8.2 & 11.9 \\
\hline Project & 4.8 & 4.1 & 5.4 \\
\hline Nonproject & 4.3 & 4.1 & 6.5 \\
\hline Overall balance after grants & -2.5 & -2.4 & -1.6 \\
\hline External borrowing (net) & 5.7 & 4.7 & 1.8 \\
\hline Disbursements & 6.8 & 5.8 & 2.7 \\
\hline Project & 4.7 & 3.5 & 2.7 \\
\hline Nonprojeet & 2.1 & 2.2 & 0.0 \\
\hline Cash amortization & 1.0 & 1.1 & 1.0 \\
\hline Domestic financing (net) & -3.2 & -2.3 & -0.2 \\
\hline Banking system & -3.2 & -2.3 & -0.3 \\
\hline Other (including residual) & 0.0 & 0.0 & 0.1 \\
\hline
\end{tabular}




$$
-91-
$$

Table 33. Mozambique: Government Revenue, 1997-99

\begin{tabular}{|c|c|c|c|}
\hline & 1997 & 1998 & 1999 \\
\hline & \multicolumn{3}{|c|}{ (In billions of meticais) } \\
\hline Total revenue & 4,586 & 5,324 & 6,207 \\
\hline Tax revenue & 4,235 & 4,932 & 5,733 \\
\hline Taxes on income and profits & 879 & 963 & 867 \\
\hline Companies & 388 & 465 & 415 \\
\hline Individuals & 491 & 498 & 452 \\
\hline Taxes on goods and services & 2,389 & 2,882 & 3,638 \\
\hline Turnover tax & 1,330 & 1,559 & 917 \\
\hline Value added tax & 0 & 0 & 1,397 \\
\hline On domestic production & 0 & 0 & 569 \\
\hline On imports & 0 & 0 & 123 \\
\hline Consumption taxes & 431 & 571 & 565 \\
\hline Tobacco & 31 & 43 & 46 \\
\hline Beer \& soft drinks & 201 & 278 & 269 \\
\hline Other domestic goods & 21 & 29 & 18 \\
\hline Imported products & 179 & 222 & 231 \\
\hline Tax on petroleum products & 627 & 751 & 759 \\
\hline Taxes on international trade & 812 & 937 & 1,046 \\
\hline Other taxes & 155 & 150 & 183 \\
\hline Stamp taxes & 71 & 80 & 92 \\
\hline Poll taxes & 6 & 4 & 3 \\
\hline Other taxes and duties & 79 & 66 & 88 \\
\hline Nontax revenue & 351 & 392 & 474 \\
\hline Rents from real estate & 109 & 185 & 111 \\
\hline Fees and charges & 36 & 41 & 50 \\
\hline Social security contributions & 85 & 98 & 112 \\
\hline Nonfinancial enterprise profits & 0 & 7 & 0 \\
\hline Fishing licence fees & 68 & 53 & 60 \\
\hline Net privatisation revenue & 0 & 0 & 17 \\
\hline \multirow[t]{2}{*}{ Other nontax revenues } & 52 & 8 & 124 \\
\hline & \multicolumn{3}{|c|}{ (In percent of total revenue) } \\
\hline Total revenue & 100.0 & 100.0 & 100.0 \\
\hline Tax revenue & 92.3 & 92.6 & 92.4 \\
\hline Taxes on income and profits & 19.2 & 18.1 & 14.0 \\
\hline Taxes on goods and services & 52.1 & 54.1 & 58.6 \\
\hline Taxes on international trade & 17.7 & 17.6 & 16.9 \\
\hline Other taxes & 3.4 & 2.8 & 2.9 \\
\hline Nontax revenue & 7.7 & 7.4 & 7.6 \\
\hline
\end{tabular}


Table 34. Mozambique: Locally Financed Public Investment by Sector, 1995-99

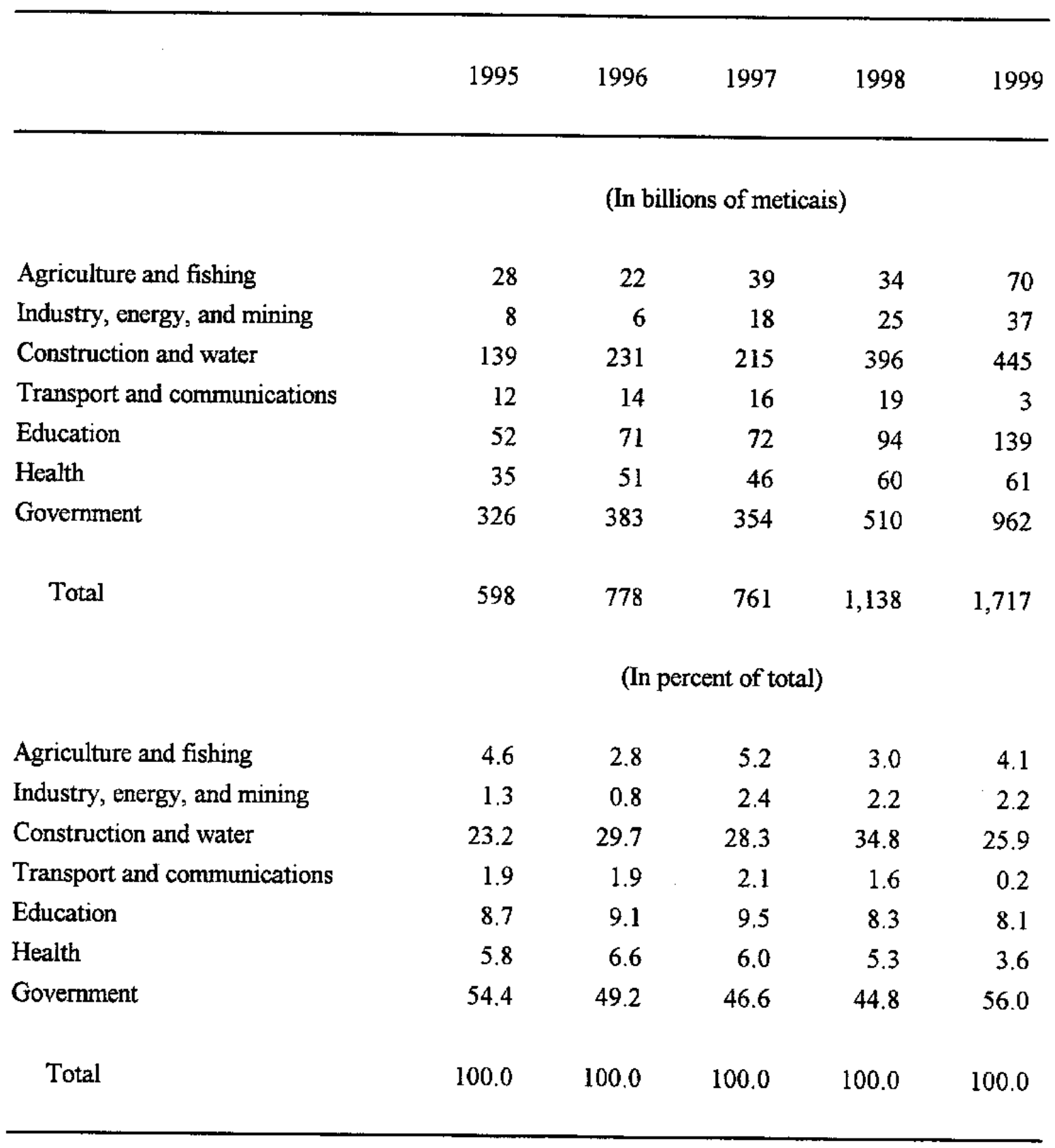

Source: Mozambican authorities. 
Table 35. Mozambique: Monetary Survey, $1995-99$

(In billions of meticais, uniess otherwise specified)

\begin{tabular}{|c|c|c|c|c|c|}
\hline & $\begin{array}{l}1995 \\
\text { Dec. }\end{array}$ & $\begin{array}{l}1996 \\
\text { Dec. }\end{array}$ & $\begin{array}{l}1997 \\
\text { Dec. }\end{array}$ & $\begin{array}{l}1998 \\
\text { Dec. }\end{array}$ & $\begin{array}{l}1999 \\
\text { Dec. }\end{array}$ \\
\hline \multicolumn{6}{|l|}{ Central bank } \\
\hline Net foreign assets & $-5,756$ & $-3,805$ & $-2,653$ & $-1,973$ & $-1,384$ \\
\hline (in millions of U.S. dollars) & -529 & -334 & -230 & -160 & -104 \\
\hline Net international reserves & $-2,198$ & $-2,059$ & 4,021 & 5,214 & 6,242 \\
\hline (in millions of U.S. dollars) & -202 & -181 & 348 & 422 & 469 \\
\hline Medium- and long-term foreign liabilities & $-6,005$ & $-6,120$ & $-6,830$ & $-7,338$ & $-7,819$ \\
\hline Other & 2,447 & 4,374 & 156 & 151 & 193 \\
\hline Net domestic assets & 7,703 & 6,238 & 5,445 & 4,665 & 4,501 \\
\hline Credit to government (net) & $-1,053$ & $-2,547$ & $-3,852$ & $-4,898$ & $-5,175$ \\
\hline Credit to banks (net) & 735 & 769 & 567 & 454 & 408 \\
\hline Credit to the economy & 51 & 48 & 55 & 75 & 74 \\
\hline Other items (net; assets + ) & 7,970 & 7,969 & 8,675 & 9,033 & 9,194 \\
\hline Reserve money & 1,948 & 2,433 & 2,792 & 2,692 & 3,117 \\
\hline Currency outside banks & 1,130 & 1,394 & 1,544 & 1,650 & 2,174 \\
\hline Bank reserves & 818 & 1,039 & 1,248 & 1,042 & 943 \\
\hline Currency in banks & 170 & 270 & 282 & 269 & 391 \\
\hline Deposits in meticais & 520 & 617 & 861 & 639 & 237 \\
\hline Required reserves (calculated) & 355 & 400 & 473 & 530 & 710 \\
\hline Free reserves (calculated) & 164 & 216 & 388 & 109 & -473 \\
\hline Deposits in foreign currencies & 128 & 152 & 105 & 134 & 315 \\
\hline (in millions of U.S. dollars) & 12 & 13 & 9 & 11 & 24 \\
\hline \multicolumn{6}{|l|}{ Deposit money banks (DMBs) } \\
\hline Net foreign assets & 2,237 & 2,186 & 1,784 & 1,721 & 2,109 \\
\hline (in millions of U.S. dollars) & 205 & 192 & 155 & 139 & 159 \\
\hline Net domestic assets & 1,553 & 2,378 & 4,086 & 5,350 & 7,502 \\
\hline Banks' reserves & 839 & 1,111 & 1,390 & 1,310 & 1,013 \\
\hline Liabilities to central bank (net) & -668 & -687 & -555 & -337 & -307 \\
\hline Credit to government (net) & -584 & -540 & -576 & -714 & -441 \\
\hline Of which: government deposits & -585 & -606 & -680 & -724 & -824 \\
\hline Credit to the economy & 2,485 & 3,517 & 5,350 & 6,649 & 8,645 \\
\hline Of which: in foreign currency & 0 & 0 & 1,426 & 1,918 & 2,934 \\
\hline (in millions of U.S. dollars) & 0 & 0 & 124 & 155 & 221 \\
\hline Other items (net; assets + ) & -5.19 & $-1,024$ & $-1,523$ & $-1,559$ & $-1,408$ \\
\hline Deposits & 3,790 & 4,564 & 5,869 & 7,070 & 9,611 \\
\hline Demand and savings deposits & 3,363 & 3,843 & 4,579 & 5,370 & 7,293 \\
\hline Time deposits & 427 & 721 & 1,290 & 1,701 & 2,318 \\
\hline \multicolumn{6}{|l|}{ Monetary survey } \\
\hline Net foreign assets & $-3,519$ & $-1,619$ & $-869^{\prime}$ & -253 & 725 \\
\hline Net domestic assets & 8,439 & 7,578 & 8,282 & 8,973 & 11,059 \\
\hline Domestic credit & 900 & 478 & 977 & 1,112 & 3,104 \\
\hline Credit to government (net) & $-1,636$ & $-3,087$ & $-4,429$ & $-5,612$ & $-5,616$ \\
\hline Credit to the economy & 2,536 & 3,565 & 5,406 & 6,725 & 8,720 \\
\hline Other items (net; asset + ) & 7,539 & 7,099 & 7,306 & 7,860 & 7,956 \\
\hline Of which: diserepancy between central bank and DMBs & 88 & 155 & 154 & 386 & 170 \\
\hline Money and quasi money (M2) & 4,920 & 5,958 & 7,414 & 8,720 & 11,785 \\
\hline Currency outside banks & 1,130 & 1,394 & 1,544 & 1,650 & 2,174 \\
\hline Deposits & 3,790 & 4,564 & 5,869 & 7,070 & 9,611 \\
\hline Of which : foreign currency deposits & 2,031 & 2,464 & 2,584 & 3,045 & 4,151 \\
\hline (in millions of U.S. dollars) & 187 & 217 & 224 & 246 & 312 \\
\hline \multicolumn{6}{|l|}{ Memorandum items: } \\
\hline Money growth (12-month percent change) & 54.7 & 21.1 & 24.4 & 17.6 & 35.1 \\
\hline Credit to the economy (12-month percent change) & 48.2 & 40.6 & 51.6 & 24.4 & 29.7 \\
\hline Currency/M2 (in percent) & 23.0 & 23.4 & 20.8 & 18.9 & 18.4 \\
\hline Velocity of money (average) & 11.39 & 8.48 & 6.90 & 5.72 & 5.16 \\
\hline
\end{tabular}


Table 36. Mozambique: Interest Rates, 1995-99 I/ (In percent)

\begin{tabular}{|c|c|c|c|}
\hline & \multicolumn{2}{|c|}{ Commercial Banks $2 /$} & \multirow{2}{*}{$\begin{array}{c}\text { Central Bank } \\
\text { Rediscount }\end{array}$} \\
\hline & Deposit & Lending & \\
\hline \multicolumn{4}{|l|}{1995} \\
\hline Q1 & 30.2 & 43.8 & 69.70 \\
\hline Q2 & 30.8 & 42.4 & 69.70 \\
\hline Q3 & 35.6 & 41.9 & 69.70 \\
\hline Q4 & 35.0 & 43.9 & 57.75 \\
\hline \multicolumn{4}{|l|}{1996} \\
\hline Q1 & 26.2 & 44.7 & 57.75 \\
\hline Q2 & 26.4 & 44.5 & 57.75 \\
\hline Q3 & 29.8 & 44.0 & 48.75 \\
\hline Q4 & 29.2 & 43.4 & 32.00 \\
\hline \multicolumn{4}{|l|}{1997} \\
\hline Q1 & 30.1 & 35.8 & 24.75 \\
\hline Q2 & 25.0 & 32.3 & 23.50 \\
\hline Q3 & 14.9 & 33.8 & 19.95 \\
\hline Q4 & 11.1 & 27.5 & 12.95 \\
\hline \multicolumn{4}{|l|}{1998} \\
\hline Q1 & 8.9 & 27.6 & 12.95 \\
\hline Q2 & 8.8 & 25.4 & 9.95 \\
\hline Q3 & 8.8 & 25.4 & 9.95 \\
\hline Q4 & 8.8 & 25.4 & 9.95 \\
\hline \multicolumn{4}{|l|}{1999} \\
\hline Q1 & 8.8 & 23.5 & 9.95 \\
\hline Q2 & 8.8 & 23.4 & 9.95 \\
\hline Q3 & 8.8 & 23.3 & 9.95 \\
\hline Q4 & 8.8 & 23.2 & 9.95 \\
\hline
\end{tabular}

Source: Bank of Mozambique

1/ At end of each quarter.

2/ Arithmetic average rates. 
Table 37. Mozambique: Balance of Payments, 1995-99

(In millions of U.S. dollars, unless otherwise specified)

\begin{tabular}{|c|c|c|c|c|c|}
\hline & 1995 & 1996 & 1997 & 1998 & 1999 \\
\hline Trade balance & -552.7 & -556.5 & -530.0 & -572.7 & -928.9 \\
\hline Exports (f.o.b.) & 174.3 & 226.1 & 230.0 & 244.6 & 270.9 \\
\hline Imports (c.j.f.) & -727.0 & -782.6 & -760.0 & -817.3 & $-1,199.8$ \\
\hline Services (net) & -124.1 & -90.1 & -80.8 & -176.3 & -275.0 \\
\hline Receipts & 291.7 & 314.2 & 342.3 & 332.5 & 353.4 \\
\hline Expenditures & -415.8 & -404.3 & -423.1 & -508.8 & -628.4 \\
\hline Of which : interest on public debt & -144.2 & -144.2 & -140.2 & -150.2 & -161.6 \\
\hline interest on private debt $1 /$ & 0.0 & -3.6 & -7.1 & -13.0 & -36.1 \\
\hline Current account, excluding grants & -676.8 & -646.6 & .610 .8 & -749.0 & $-1,203,9$ \\
\hline Unrequited official transfers 2 & 339.2 & 224.7 & 312.9 & 313.2 & 434.1 \\
\hline Current account, including grants & -337.6 & -421.9 & -297.9 & -435.8 & .769 .8 \\
\hline Capital account & 63.8 & 248.0 & 180.8 & 262.8 & 613.4 \\
\hline Foreign borrowing & 282.3 & 347.4 & 316.3 & 299.5 & 472.0 \\
\hline Public & 234.7 & 271.1 & 226.3 & 218.1 & 111.7 \\
\hline Private $1 /$ & 47.6 & 76.3 & 90.0 & 81.4 & 360.3 \\
\hline Amortization & -263.5 & -171.9 & -201.0 & -249.4 & -240.3 \\
\hline Public & -263.5 & -171.9 & -180.0 & -211.2 & -200.7 \\
\hline Private $1 /$ & 0.0 & 0.0 & -21.0 & -38.3 & -39.6 \\
\hline Direct imvestment (net) & 45.0 & 72.5 & 64.4 & 212.7 & 381.7 \\
\hline Short-term capital and errors and omissions (net) & 10.1 & 132.9 & 19.5 & -31.4 & -86.0 \\
\hline Of which : commercial banks (NFA; increase -) & -28.9 & 13.2 & 33.5 & 15.3 & -20.4 \\
\hline Overall balance & -263.7 & -41.0 & -97.6 & -204.4 & -242.5 \\
\hline Financing & 263.7 & 41.0 & 97.6 & 204.4 & 242.5 \\
\hline Bank of Mozambique (NFA; increase -) & -30.7 & .172 .5 & -148.1 & -77.2 & -50.7 \\
\hline Gross intemational reserves (increase-) & -16.4 & -158.4 & -167.7 & -92.9 & -44.4 \\
\hline Use of MF credit (net) & -14.3 & -14.0 & 19.6 & 9.6 & -2.5 \\
\hline Other (net) & 0.0 & 0.0 & 0.0 & 6.1 & -3.8 \\
\hline Net change in arrears (increase + ) & 173.6 & -48.9 & .3932 .2 & 20.4 & -761.5 \\
\hline Debt rolief $3 /$ & 120.9 & 262.4 & 4177.9 & 261.2 & $1,054.7$ \\
\hline Debt relief on traditional mechanisms & 120.9 & 262.4 & 4177.9 & 261.2 & $1,003,4$ \\
\hline Financing gap & 0.0 & 0.0 & 0.0 & 0.0 & 0.0 \\
\hline \multicolumn{6}{|l|}{ Memorandum items: } \\
\hline \multicolumn{6}{|l|}{ Current account deficit (in percent of GDP) } \\
\hline Before grants & 166.3 & 22.3 & 17.8 & 21.3 & 30.1 \\
\hline After grants & 83.0 & 14.6 & 8.7 & 12.4 & 19.2 \\
\hline Gross international reserves & 225.0 & 383.4 & 532.0 & 624.9 & 669.3 \\
\hline (in months of imports of goods and nonfactor services) & 3.0 & 4.8 & 6.8 & 7.0 & 5.2 \\
\hline \multicolumn{6}{|l|}{ Debt-gervice ratio 4} \\
\hline Before HIPC Initiative assistance (Naples terms) & 74.0 & 47.4 & 24.8 & 20.0 & 26.1 \\
\hline After original HIPC Initiative assistance & $\ldots$ & $\ldots$ & $\ldots$ & $\ldots$ & 15.3 \\
\hline After enhanced HIIPC Initiative assistance & $\ldots$ & $\ldots$ & $\ldots$ & $\ldots$ & $\ldots$ \\
\hline Actual payments & 31.3 & 28.9 & 23.4 & 20.0 & 15.3 \\
\hline
\end{tabular}

Sources: Mozambican authorities; and staff estimates and projections.

1) Private borrowing not guaranteed by the government or the Bank of Mozambique.

2/ In 1999 includes US\$150 million of grants provided by DA as interim assistance under the original HIPC Initiative.

3/ Includes the 1996 Paris Club flow rescheduling on Naples terms; the rescheduling of the debt to Russia after an up-front discount of 80 percent; the 1997 conmercial debt rescheduling with the Bank of Brazil; total assistance under the HIPC Initiative;

the recent Paris Club deferral; and the application of traditional rescheduling mechanisms by non-Paris Club creditors.

4) Nonfinancial public sector, in percent of exports of goods and nonfactor services. 
Table 38. Mozambique: Foreign Trade Indicators, 1995-99 1/

\begin{tabular}{|c|c|c|c|c|c|}
\hline & 1995 & 1996 & 1997 & 1998 & 1999 \\
\hline Indices & \multicolumn{5}{|c|}{$(1990=100)$} \\
\hline \multicolumn{6}{|l|}{ Exports } \\
\hline Value & 137.9 & 178.9 & 182.0 & 193.6 & 214.4 \\
\hline Prices 2/ & 91.0 & 90.1 & 90.0 & 87.3 & 87.5 \\
\hline Volume 3/ & 151.5 & 198.5 & 202.3 & 221.6 & 244.9 \\
\hline \multicolumn{6}{|l|}{ Imports } \\
\hline Value & 93.2 & 100.3 & 97.4 & 104.8 & 153.8 \\
\hline Prices 4/ & 109.3 & 108.7 & 101.8 & 93.8 & 94.0 \\
\hline Volume $3 /$ & 85.3 & 92.9 & 95.7 & 111.7 & 163.6 \\
\hline Terms of trade & 83.3 & 82.9 & 88.4 & 93.1 & 93.1 \\
\hline Annual changes & \multicolumn{5}{|c|}{ (In percentage) } \\
\hline \multicolumn{6}{|l|}{ Exports } \\
\hline Value & 6.3 & 29.8 & 1.7 & 6.3 & 10.8 \\
\hline Prices 2/ & 9.9 & -1.0 & -0.2 & -2.9 & 0.2 \\
\hline Volume 3/ & -3.3 & 31.1 & 1.9 & 9.6 & 10.5 \\
\hline \multicolumn{6}{|l|}{ Imports } \\
\hline Value & -17.5 & 7.6 & -2.9 & 7.5 & 46.8 \\
\hline Prices 4/ & 10.5 & -0.5 & -6.4 & -7.8 & 0.3 \\
\hline Volume 3 / & -25.3 & 8.2 & 3.8 & 16.7 & 46.4 \\
\hline Terms of trade & -0.6 & -0.5 & 6.7 & 5.3 & -0.1 \\
\hline
\end{tabular}

Source: Staff estimates, based on data from the Bank of Mozambique and International Financial Statistics.

1) Values and prices in U.S. dollar terms.

2) Weighted average of unit values with constant weights according to the share of each item in the total of 1990.

3/ Implicit volume derived from value and prices.

4/ From international price indices (e.g., cost and prices of partner suppliers) and estimates of the Research Department, IMF. 
Table 39. Mozambique: Commodity Composition of Exports, 1995-99 1/

(Value in million of U.S. dollars; volume in thousands of metric tons; and unit values in U.S. dollars per metric ton)

\begin{tabular}{|c|c|c|c|c|c|}
\hline & 1995 & 1996 & 1997 & 1998 & 1999 \\
\hline Total exports, f.o.b. & 167.6 & 218.6 & 216.4 & 248.2 & 268.9 \\
\hline $\begin{array}{l}\text { Prawns, value } \\
\text { Volume } \\
\text { Unit value }\end{array}$ & $\begin{array}{r}73.1 \\
8.2 \\
8882.5\end{array}$ & $\begin{array}{r}70.3 \\
9.3 \\
7555.0\end{array}$ & $\begin{array}{r}85.1 \\
11.1 \\
7668.6\end{array}$ & $\begin{array}{r}72.6 \\
9.8 \\
7408.9\end{array}$ & $\begin{array}{r}65.5 \\
8.6 \\
7631.2\end{array}$ \\
\hline $\begin{array}{l}\text { Cashew nuts, value } \\
\text { Volume } \\
\text { Unit value }\end{array}$ & $\begin{array}{r}6.9 \\
2.0 \\
3533.0\end{array}$ & $\begin{array}{r}17.2 \\
4.5 \\
3818.6\end{array}$ & $\begin{array}{r}0.0 \\
3.8 \\
3713.1\end{array}$ & $\begin{array}{r}19.1 \\
4.9 \\
3894.2\end{array}$ & $\begin{array}{r}7.8 \\
1.9 \\
4175.8\end{array}$ \\
\hline $\begin{array}{l}\text { Cotton, value } \\
\text { Volume } \\
\text { Unit value }\end{array}$ & $\begin{array}{r}19.8 \\
16.7 \\
1181.3\end{array}$ & $\begin{array}{r}26.8 \\
18.8 \\
1427.7\end{array}$ & $\begin{array}{r}25.2 \\
15.6 \\
1611.3\end{array}$ & $\begin{array}{r}22.3 \\
18.7 \\
1194.6\end{array}$ & $\begin{array}{r}19.9 \\
20.5 \\
968.8\end{array}$ \\
\hline $\begin{array}{l}\text { Tea, value } \\
\text { Volume } \\
\text { Unit value }\end{array}$ & $\begin{array}{r}0.0 \\
0.2 \\
141.2\end{array}$ & $\begin{array}{r}0.0 \\
0.0 \\
141.2\end{array}$ & $\begin{array}{r}0.6 \\
0.6 \\
959.3\end{array}$ & $\begin{array}{r}0.5 \\
0.4 \\
1231.5\end{array}$ & $\begin{array}{r}0.2 \\
0.2 \\
1199.5\end{array}$ \\
\hline $\begin{array}{l}\text { Sugar, value } \\
\text { Volume } \\
\text { Unit value }\end{array}$ & $\begin{array}{r}7.3 \\
16.8 \\
433.5\end{array}$ & $\begin{array}{r}12.8 \\
31.7 \\
404.1\end{array}$ & $\begin{array}{r}12.8 \\
31.9 \\
402.3\end{array}$ & $\begin{array}{r}8.4 \\
20.4 \\
413.3\end{array}$ & $\begin{array}{r}5.5 \\
13.9 \\
395.9\end{array}$ \\
\hline $\begin{array}{l}\text { Copra, value } \\
\text { Volume } \\
\text { Unit value }\end{array}$ & $\begin{array}{r}6.1 \\
20.8 \\
294.0\end{array}$ & $\begin{array}{r}3.7 \\
11.8 \\
312.7\end{array}$ & $\begin{array}{r}4.6 \\
14.1 \\
326.4\end{array}$ & $\begin{array}{r}5.0 \\
18.2 \\
276.0\end{array}$ & $\begin{array}{r}3.5 \\
16.6 \\
210.8\end{array}$ \\
\hline $\begin{array}{l}\text { Citrus, value } \\
\text { Volume } \\
\text { Unit value }\end{array}$ & $\begin{array}{r}1.3 \\
5.5 \\
233.4\end{array}$ & $\begin{array}{r}1.0 \\
4.9 \\
209.4\end{array}$ & $\begin{array}{r}0.8 \\
2.6 \\
286.8\end{array}$ & $\begin{array}{r}0.4 \\
3.6 \\
101.5\end{array}$ & $\begin{array}{r}5.8 \\
57.8 \\
100.3\end{array}$ \\
\hline $\begin{array}{l}\text { Petroleum, value } 2 / \\
\text { Volume } \\
\text { Unit value }\end{array}$ & $\begin{array}{r}4.5 \\
8.0 \\
562.0\end{array}$ & $\begin{array}{r}2.6 \\
4.5 \\
570.0\end{array}$ & $\begin{array}{r}2.4 \\
3.8 \\
633.4\end{array}$ & $\begin{array}{r}1.3 \\
0.0 \\
430.1\end{array}$ & $\begin{array}{r}4.4 \\
7.4 \\
591.3\end{array}$ \\
\hline $\begin{array}{l}\text { Coal, value } \\
\text { Volume } \\
\text { Unit value }\end{array}$ & $\begin{array}{r}0.5 \\
19.0 \\
26.1\end{array}$ & $\begin{array}{r}0.4 \\
22.0 \\
16.7\end{array}$ & $\begin{array}{r}0.3 \\
18.5 \\
14.0\end{array}$ & $\begin{array}{r}0.2 \\
16.0 \\
14.0\end{array}$ & $\begin{array}{r}0.0 \\
0.0 \\
14.2\end{array}$ \\
\hline $\begin{array}{l}\text { Miscellaneous, value } \\
\text { Aluminum } \\
\text { Electricity } \\
\text { Unprocessed cashew nuts } \\
\text { Timber } \\
\text { Minerals } 3 / \\
\text { Fishery products 4/ } \\
\text { Manufacturing products } \\
\text { Tires and tubes } \\
\text { Other }\end{array}$ & $\begin{array}{r}48.0 \\
0.0 \\
0.0 \\
5.6 \\
9.6 \\
6.0 \\
3.6 \\
5.1 \\
2.7 \\
15.3\end{array}$ & $\begin{array}{r}81.5 \\
0.0 \\
0.0 \\
29.3 \\
9.8 \\
4.5 \\
9.0 \\
8.3 \\
2.4 \\
18.2\end{array}$ & $\begin{array}{r}81.4 \\
0.0 \\
0.0 \\
15.1 \\
13.8 \\
3.3 \\
7.2 \\
19.9 \\
3.3 \\
18.8\end{array}$ & $\begin{array}{r}76.8 \\
0.0 \\
36.2 \\
21.6 \\
11.0 \\
3.4 \\
5.6 \\
14.3 \\
3.4 \\
37.5\end{array}$ & $\begin{array}{r}88.4 \\
0.0 \\
62.9 \\
25.1 \\
8.8 \\
3.6 \\
8.9 \\
13.9 \\
1.0 \\
27.1\end{array}$ \\
\hline
\end{tabular}

Sources: Mozambican authorities and staff estimates.

1/ Information on export volumes and prices is not availabie from the National Institute of Statistics (INE). These figures were obtained from the Ministry of Commerce, Industry, and Tourism and differ from the export figures presented in the balance of payments which are based on INE.

2/ Petroleum products, including bunkers.

3/ Excludes coal.

4/ Excludes prawns. 
Table 40. Mozambique: Exports by Country of Destination, 1995-99 (In percent of total exports)

\begin{tabular}{|c|c|c|c|c|c|}
\hline & 1995 & 1996 & 1997 & 1998 & 1999 \\
\hline OBCD countries & 60.7 & 54.8 & 57.3 & 37.8 & 37.3 \\
\hline Japan & 14.2 & 7.6 & 8.4 & 4.8 & 4.3 \\
\hline Netherlands & 1.8 & 1.5 & 3.0 & 2.3 & 1.7 \\
\hline Portugal & 8.4 & 7.7 & 8.9 & 7.6 & 9.0 \\
\hline Spain & 20.9 & 21.1 & 18.5 & 13.0 & 12.7 \\
\hline United Kingdom & 0.5 & 1.3 & 0.7 & 1.4 & 1.0 \\
\hline United States & 5.5 & 11.4 & 11.5 & 5.7 & 4.7 \\
\hline Other & 9.4 & 4.2 & 6.3 & 3.0 & 3.9 \\
\hline Other countries & 39.3 & 45.2 & 42.7 & 62.2 & 62.7 \\
\hline South Africa & 23.6 & 19.3 & 17.5 & 17.6 & 26.2 \\
\hline Zimbabwe & 4.5 & 4.3 & 4.1 & 19.5 & 14.9 \\
\hline Other & 11.2 & 21.6 & 21.1 & 25.1 & 21.7 \\
\hline Total & 100.0 & 100.0 & 100.0 & 100.0 & 100.0 \\
\hline \multicolumn{6}{|l|}{ Memorandum item: } \\
\hline Total exports (millions of U.S. dollars) & 174.3 & 226.1 & 230,0 & 248.2 & 268.9 \\
\hline
\end{tabular}

Source: Mozambican authorities. 
Table 41. Mozambique: Imports by Country of Origin, 1995-99 (In percent of total imports)

\begin{tabular}{lrrrrr}
\hline & 1995 & 1996 & 1997 & 1998 & 1999 \\
\hline OBCD countries & 46.7 & 39.6 & 37.3 & 31.9 & 27.2 \\
France & 3.3 & 4.4 & 2.7 & 2.1 & 0.9 \\
Japan & 5.1 & 4.0 & 4.5 & 3.9 & 3.9 \\
Netherlands & 2.4 & 2.0 & 1.3 & 0.8 & 0.7 \\
Portugal & 9.0 & 6.3 & 6.1 & 7.9 & 5.6 \\
$\quad$ United Kingdom & 3.6 & 2.3 & 2.1 & 2.0 & 0.9 \\
United States & 6.9 & 4.2 & 5.2 & 5.3 & 6.7 \\
Other & 16.4 & 16.4 & 15.4 & 9.9 & 8.54 \\
& & & & & \\
Other countries & 53.3 & 60.4 & 62.7 & 68.1 & 72.8 \\
South Africa & 25.9 & 33.2 & 40.9 & 39.5 & 57.2 \\
Zimbabwe & 4.2 & 3.9 & 2.3 & 2.3 & 0.5 \\
Other & 23.2 & 23.3 & 19.5 & 26.3 & 15.1 \\
Total & 100.0 & 100.0 & 100.0 & 100.0 & 100.0 \\
Memorandum item: & & & & & \\
Total imports (millions of U.S. dollars) & 727.0 & 782.6 & -760.0 & -817.3 & -1199.8 \\
\hline
\end{tabular}

Source: Mozambican authorities. 
Table 42. Mozambique: Exchange Rates, 1980-2000

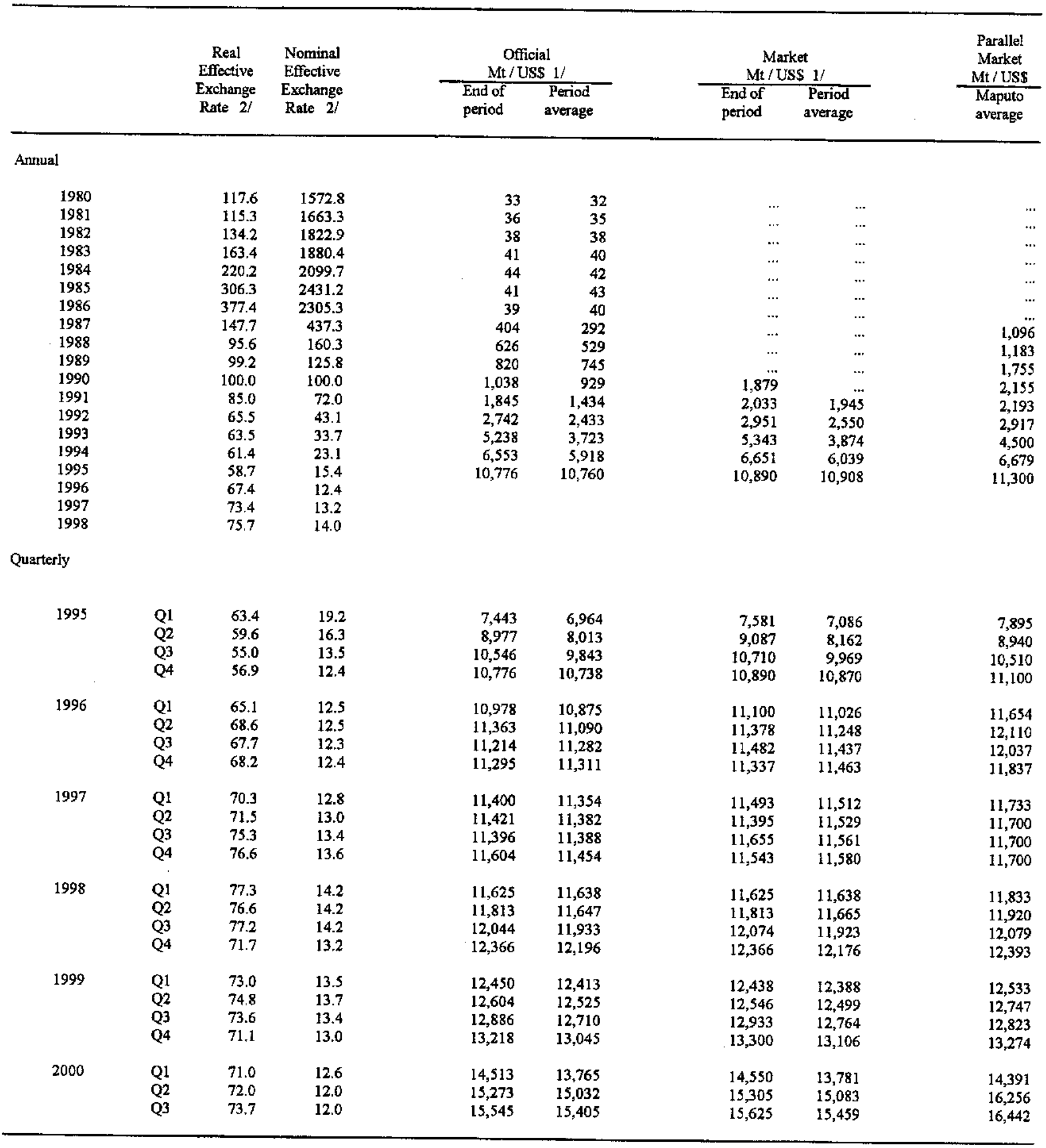

Sources: Bank of Mozambique; and MM, International Financial Statistics.

1/ Mid-point official exchange rates; buying and selling rates plus/minus 1 percent.

2f Per metical; index 1990=100. 
Mozambique: Summary of Major Taxes, November 2000

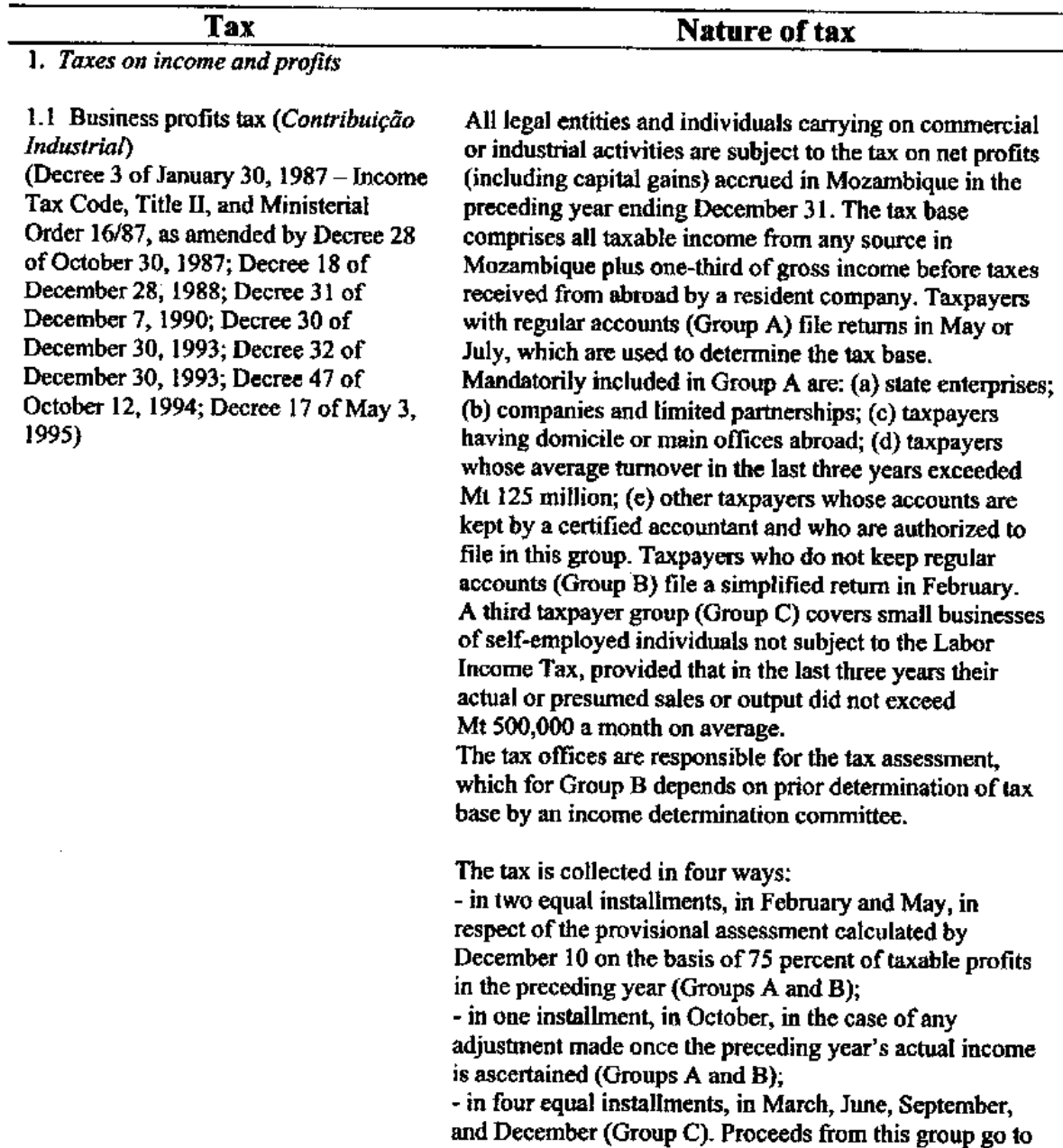

Exemptions and deductions

Exempted are (a) the State and its agencies; (b) social security institutions; (c) income of production or services cooperatives subject to the Labor Income Tax -Section B; (d) cultural, recreational, physical education, or sports

associations having approved charters; (e) income of social assistance, public health, charitable, educational, scientific, literary, artistic, sports, recreational, preservation, and restoration associations or other entities.

Deductible are (Group A only) (a) required contributions (not including payments made to nonresidents unless it can be proven that these payments are essential for the generation of income); (b) expenditure incurred in providing various types of medical and social assistance to employees and their families; (c) taxes other than the business profits tax itself; (d) losses from the three previous years; (e) donations up to the equivalent of 8 percent of taxable income in the previous year (grants to the State are fully

deductible); and (f) straight-line depreciation at rates established by the Ministry of Planning and Finance or calculated according to another method authorized by the tax administration.

.

Rates

Groups A and B

35 percent for agriculture;

40 percent for manufacturing; and

45 percent for all other activities.

Quittance rate

15 percent of gross incorne of nonresident entities or enterprises which do not provide proof of tax registration, withheld at source by the paying entity or enterprise.

Group C

Specific rates are established by each provincial government by October 31 of the preceding year, at levels at least equal to and at most twice those determined by the Ministry of Planning and Finance.

Examples of the minimum rates determined by the Ministry of Planning and Finance are the following:

(In thousands of meticais)

Maputo/ Zambézia/

Sofala Nampula Other

Basket or mat

maker

Artisan

$20 \quad 20 \quad 20$

Photographer,

without studio

Ivory artisan,

construction

electrician

20

30

$10 \quad 10$

Watch 20

repairman, confec-

$30 \quad 20$

$30 \quad 20$ 


\begin{tabular}{|c|c|c|c|}
\hline \multicolumn{4}{|c|}{ Rates } \\
\hline tioner, barber & 60 & 40 & 30 \\
\hline \multicolumn{4}{|c|}{ Motorcycle mechanic, } \\
\hline bricklayer & 80 & 50 & 40 \\
\hline $\begin{array}{l}\text { Housepainter o } \\
\text { whitewasher, }\end{array}$ & & & \\
\hline $\begin{array}{l}\text { hairdresser } \\
\text { Tailor, street } \\
\text { photographer, } \\
\text { studio photog }\end{array}$ & 120 & 80 & 60 \\
\hline upholsterer & 150 & 100 & 80 \\
\hline \multicolumn{4}{|c|}{$\begin{array}{l}\text { Dressmaker, auto } \\
\text { mechanic, electric } \\
\text { and electronic } \\
\text { appliance }\end{array}$} \\
\hline $\begin{array}{l}\text { repairman } \\
\text { Carpenter or }\end{array}$ & 200 & 140 & 100 \\
\hline cabinetmake & 250 & 150 & 88 \\
\hline
\end{tabular}

Decree 68 of December 23, 1998 (amends Article 96(d) and Article 99(c) of Decree 30 of December 30, 1993) provincial treasuries; and

- in eight installments, beginning in May, in the case of

prepayment of the provisional assessment by Groups $A$ and

$B$ taxpayers whose average turnover exceeded

Mt 125 million in the preceding year, as determined on the basis on estimated current year profits in accordance with financial plan submitted by the taxpayer by March 31 .

Taxpayers whose turnover in the preceding year exceeded 500 thousand contos are classified in Group $\mathrm{A}$

Taxpayers whose average actual or presumptive sales or

production in the preceding year did not exceed

Mt 2 million a month are classified in Group C.
Decree 44 of August 10, 1999 (amends Articles 101 and 167)
Exempted are income subject to the Labor Income Tax - Section B; income subject to the sales and manufacturing taxes and the Labor Income TaxSection B, both created by Law 11 of March 31 Section B, both created by Law 11 of March 31,
1997; cultural, recreational, physical education, or
Groups A and B

The rate is 35 percent.

15 percent of gross income of nonresident individuals or legal entities who are not registered taxpayers, where such income is derived from the following commercial or industrial activities:

(a) intellectual or industrial property

(b) provision of information in respect of

experience acquired in the industrial,

commercial, or scientific sectors;

(c) technical assistance services,

(d) use or licensing of agricultural,

commercial, industrial, or scientific equipment.

Agricultural and livestock activities will benefit from a reduced 10 percent rate for ten tax years, from 1998 through 2007. 
Also exempted is interest on bonds and dividends on shares listed in the Mozambique stock exchange, as well as capital gains on the sale of shares acquired and sold through the Mozambique stock exchange.

Decree 83 of November 16,1999 (amends Articles 101 and 113 )

\subsection{Taxes on individual income}

1.2.1 Labor income tax (Imposto sobre os Rendimentos do Trabalho) -

Sections $\mathrm{A}$ and $\mathrm{B}$

(Decree 3 of January 30, 1987 - Incorne

Tax Code, Title III, as amended by

Decree 8 of May 13, 1988; Decree 18 of

December 28, 1988; Decree 31 of

December 7, 1990; Decrees 30 and 32

of December 30, 1993; Decree 8 of

February 27, 1995; Decree 25 of

June 26, 1996; Decree 23 of May 26,

1998)

\section{$\underline{\text { Section A }}$}

Tax withheld by employers on salaries and other remuneration paid in cash or in kind to national or foreig workers. Also taxable are professional fees, retainers, bonuses, profit sharing, prizes, and similar income; representation and travel allowances; scholarships; remuneration of individual owners or partners that is accounted for as salary; and taxes and required

contributions withheld by employers or paid on self employment income.

The tax office assesses the tax owed by workers who render remunerated services under retainer or similar arrangements. In this case, the taxpayer files his return in January, has his income determined by a committee by

May 31, and pays tax in July. The same applies if tax

cannot be legally witheld, and the return is filed in March. $\underline{\text { Section A }}$

Exempted are (a) government employees whose salaries are paid from the state budget; (b) foreign diplomats who are nationals of the country they represent, provided there is reciprocity of treatment; (c) personnel of foreign or international

organizations; (d) monthly remuneration equal to or less than the higher of Mt 600,000 or the minimum wage.

After deduction of the tax, disposable income cannot be less than the exemption ceiling.

The following are excluded from the tax base: (a) retirement and disability pensions; (b) cashshortage allowances, up to the ceiling established for government employees earning equivalent remuneration; (c) family and separation allowances; (d) wages of occasional farm workers and househol servants; and (e) income subject to the Labor income Tax - Section A, at a quittance rate of 30 percent.

\section{Section A}

A. Wages in Mt Rates Deductible

a) Up to 600,000 exempt

b) From 600,001

$$
\text { to } 2,400,000 \quad 10 \quad 60,000
$$

c) From $2,400,001$

to $9,600,000$

d) Above 9,600,000 20

180,000

Fees, retainers, attendance fees, bonuses, percentages, commissions, profit-sharing prizes, and similar income; retainer or equivalent fees received from one or more enterprises, and self-employment income. as well as any bonuses received from an entity other than the regular employer, are subject to the following rates:
a) Up to Mt $9,000,000$
15 percent
b) Above Mt $9,000,000$
20 percent

Income earned by nonresidents cartying on professional activities for third parties or 
6 percent withheld at source by those who hire resident or nontesident actors, dancers, variety and circus performers, musicians, singers, sportsmen, and similar professionals.

15 percent for other income, such as occasional income of wage eamers, or honoraria received by partners and owners, and payments for services rendered.

Section B

Tax on presumptive income of production or service cooperatives and of individuals carrying on agricultural, forestry, and livestock operations exceeding size and development criteria established by the Minister of Planning and Finance in consultation with the Minister of Agriculture and Fisheries. These criteria refer to the size of the operation, the use of tractors, and number of

employees, according to the activity. The tax is assessed by the tax office and paid in up to four quarterly installments in July, October, January, and April.

Decree 44 of August 10, 1999 (amend Articles 177, 178, 181, 187, 188, and 221)

Decree 19 of July 19, 2000 (amends Articles 177 and 187 of the Income Tax Code approved by Decree 3 of

January 30, 1987)

\section{Section B}

The code provides for temporary excmption of taxpayers who are unable to meet tax obligations because of natural disasters; exemption is granted by

the Minister of Planning and Finance upon proposal of provincial governments.

Section A. Also exempted are those taxpayers whose monthly base income and occasional income is equal to or less than Mt 600,000 or the minimum. wage established by law, whichever is greater. Section B. Entities subject to the Labor Income Tax - Section B, are exempted from this tax.

Also exempted are those taxpayers whose monthly base income and occasional income is equal to or less than the minimum wage established by law, if this is higher than the legal minimum.

Monthly base and occasional income is subject to the following rates:

\section{Rates Deductible}

Up to 700,000

From 700,001 to

$2,800,000$

From $2,800,001$ to

$11,200,000$

Above $11,200,000$

10

70,000

$15 \quad 210,000$

20

770,000

Exempted are (a) salaries of foreign diplomatic and

Taxable annual income 
30, 1987 - Income Tax Code, Title IV,

as amended by Decree 18 of

December 28, 1988, Decree 30 of

December 7, 1990, and Decrees 30 and

32 of December 30, 1993)

Decree 44 of Augrst 10, 1999 (amends Articles 271 and 280)

\section{Decree 83 of November 16, 1999}

2. Taxes on goods and services

2.1 Value-added tax

(Law 3 of January 30, 1987, as individual income, excluding income subject to the Labor Income Tax - Section A, received by Mozambican residents from Mozambican sources; (b) capital income generated in Mozambique, even if the payee cannot be individually identified or if earned by legal entities. The sum of profits from commercial and industrial activities and capital income is taxable. Taxpayers are assessed on aggregate household income; and (c) capital gains from equity sales, including their amortization.

In the case of a company subject to the Business Profits Tax (Group B), the Complementary Tax is chargeable to the company on the difference between taxable profits, net of the corresponding tax, and the declared distribution of earnings.

Payment is made in November.

Labor income earners are subject to withholding at source of the Complementary Tax on the excess of their adjusted annual income (including income of other household members, if any, and net of Labor Income Tax - Section A payments) over the applicable personal allowance.

Also subject to withholding at source are: capital income paid to legal entities, at 18 percent; profits attributed to partners, at 18 percent; amounts paid as professional fees, retainers, bonuses, and similar income; and capital income other than the above, at 5 percent. consular officials and of personnel in their mission (b) interest on treasury bills and govemment securities; (c) interest on demand and time deposits; (d) income subject to the Labor Income Tax Section B; (e) income of taxpayers subject to the Business Profits Tax (Group C); and (f) other income specifically exempted by special provision.

Also deducted from overall income are (a) Business Profits Tax paid on overall income; (b) donations to social assistance and other associations or entities, up to 15 percent of the previous year's taxable income; and (c) donations to the State and any of its agencies or establishments.

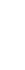

(n)


Tax

amended by Law 3 of January 8, 1998,

Decree 51 of September 29, 1998, [as

amended by Decree] 34 of June 1, 1999.

Decree 77 of December 29, 1998,

Decree 78 of December 29, 1998,

Decree 16 of April 27, 1999, Decree 33

of June 1, 1999, Decree 35 of June 1

1999, Decree 36 of June 1, 1999

Decree, Orders of May 14 and 26 ,

Orders of June 15 and 28 and July 7,15

and 29, 1999, Ministerial Order 72 of

May 25, 1999)

\section{Nature of tax} consideration by taxpayers in the national territory.

The tax base of sales of goods and services is the consideration paid or payable. The tax base of imports is the customs value, plus customs duties, surcharges, and excise taxes.

As a general rule, the tax liability is determined by the taxpayers thenselves (self-assessment), but in certain case it is determined by the National Directorate of Taxes and Auditing (quasi-official or additional assessment). The assessment is made net of taxes levied on taxable operations.

The tax is assessed based on invoices, which should be issued within five business days from the day the tax is due
Exemptions and deductions insurance, and reinsurance operations (including social security); nonprofit activities (educational, recreational, cultural, religious, political, and so on); funeral services; rental of housing; gambling and entertainment activities; sale of cultural, educational, technical or recreational newspapers, magazines, and books; sale of corn flour, rice,

bread, powdered milk for infants (up to one year) wheat, wheat flowr, fresh or refrigerated tomatoes, frozen fish (carapau), kerosene, jet fuel, mosquito nets, common bicycles, agricultural activities, public garbage collection services, sales at face value of postage stamps or stamped paper and the respective sales commissions, sale of drugs (including veterinary drugs), as well as pharmaceutical specialties and other pharmaceutical products, sate of goods resulting from the industrial production of feed for breeding animals and meat animals for human consumption, sale of equipment, seeds, brood animals, fertilizers, pesticides, herbicides, fungicides and the like, nets, fishhooks, and other fishing equipinent included in the customs tariff and listed in Attachment A to the VAT Code.

Exemptions on imports: goods whose sale locally is exempt from taxation; imports by the govemment, certain kinds of vehicles; imports by Mozambican miners living abroad, as determined by the Ministry of Planning and Finance; development projects financed by United Nations agencies and approved by the Mozambican government; transit goods, ternporary imports or reimports exempted from customs duties; gold imports by the Bank of Mozambique; stores and bunkers for ships and aircrafts; migrants, students, or military personnel who are returning definitively to Mozambique, exports and goods used in special economic zone or in duty free zones, services whose value is included in the tax base of the respective imported goods, pursuant to Article 15, imports of supplies which are to be consumed once in the national territory or during their stay in the nationa destination port or airport or are kept in international sea, river or lake vessels, or aircrafts; imports of firefighting vehicles by fire departments and associations.

The Minister of Planning and Finance may exempt
Rates

Simplified regime: 5 percent on the volume

\section{of sales.}


be provided to national institutions of public interest and of relevant social purposes, provided that those goods are fully consistent with the nature of the beneficiary institutions and are used by them in activities of clear public interest.

Exempt from VAT are shrimp larvae not exceeding 1 millimeter in length, fresh eggs, bovine semen, other, culture means for the development of microorganisms, reagents for diagnostic purposes, high resilience monofilament of over 150 decitex, nylon, polyethylene and propyline ropes $(6 \mathrm{~mm}$ or larger), compression-ignition piston engine (diesel or semidiesel) electrical generators not exceeding 75 KVA capacity, spark-ignition piston engine electrical generators, cargo transportation motor vehicles with compression-ignition piston engine (diesel or sernidiesel engines), not exceeding 5 tons capacity; extended cab and open bed, not exceeding 3,200 c.c. engine displacement.

Decree 44 of August 10, 1999 .-

amends Articles 37, 62, 63, 64, 101, $167,177,178,181,187,188,221$ and 280 and reintroducies Article 160 of the Income Tax Code (CIR), and amends Article 18.1(b)(v) of the VAT Code

Decree 79 of Novernber 11, 1999 (amends Attachment 1 to Article 33.1 of the VAT Code)

Decree 80 of November 11, 1999

Creates specific rules for the application of VAT to the public supply of drinking water, the price of which is set by a public authority. VA invoice.
Allows the deduction of the tax on the sale of goods resulting from the industrial production of feed $f o$ breeding animals and meat animals for human consumption.
Exempted from VAT are entities engaged in activities exempt from customs duties and fees on imported equipment, appliances, materials and spare parts to be used in exploration and survey or in mining; customs duties on the exploitation of

mineral resources; taxes levied on capital or loans,

and interest thereon, invested in the mining sector in the national territory, except for capital gains. 
Decree 26 of October 10,2000 - creates The tax is levied on 62 percent of the fare.

specific rules for the application of

VAT to road passenger transportation

services, at a rate set by a public

authority

Decree 27 of October 10,2000 - creates a special taxation regime for the

contracting and subcontracting of public works

Decree 28 of October 10, 2000 -

regulates the use of cash registers by

VAT taxpayers

Decree 29 of October 10,2000 -

amends Articles 11,20,64, and 74 of the VAT Code

2.2 Excise taxes (Imposto sobre Consumos Especificos)

(Decree 3 of January 30, 1987

Decree 52 of September 29,1998,

amended by Decree 31 of May 24, 1999

and Decree 79 of November 1, 1999)

Decree 79 of November 11, 1999

2.3 Special tax on fuels (Imposto Especial sobre Combustiveis)

(Decree 22 of September 24, 1990, as amended by Decree 27 of

September 30,1992, Decree of

January 4, 1993, Decree 8 of April 19 1994, Decrees 29 and 30 of August 16 ,
The tax is due upon total or partial receipt of the price, and levied on the amount received. The VAT should be

included in the invoice or equivalent document, with the option to apply the taxation rules provided for in Articles ? and 8 of the VAT Code.

Levied on certain imported or locally produced goods listed in the pertinent schedule. The tax is due on the sale by the producer and on the importation, according to the customs rules. The taxable event is the production in the national territory or the importation. The tax is levied on the final sale price or, if such price is not known or cannot be determined, on the market value of such goods, and, for imports, on the value that would be determined based on the VAT rules, even if the goods are exempt.

The tax levied on locally produced goods is payable in the month following the occurrence of the taxable event, and the tax levied on imports or goods produced in the country under a special customs regime is payable as detemined by the applicable customs laws.

Levied on all domestically produced or imported fuels intended for domestic consumption. Taxable are

(a) refiners and importers producing or marketing fuel; and

(b) individual importers of fuel for their own or others'

consumption.

Proceeds go to the central budget, except for Mt 671.40
Goods exempted from the value-added tax.

The excise taxes should not be deductible from other direct or indirect taxes.
All rates are ad valorem: 75 percent, 50 percent, 35 percent, and 20 percent

according to the kind of product.

Extended cab, open bed vehicles with

displacement above 3,200 c.c.......30 percent

(In Mt/unit)

LPG

Avgas

Regular gasoline

Premium gasoline

Jet fuel

284.00

$1,997.80$

$1,178.00$

$3,307.80$

430.20 


\begin{tabular}{l} 
Tax \\
\hline 1994, Decree 2 of January 25, 1995, \\
Decree 15 of April 25, 1995, Dected \\
of August 8, 1995, Decree 50 of \\
November 7, 1995, Decree 10 of \\
April 2, 1996, Decree 34 of July 23 \\
1996, Decree 49 of November 5, \\
Decree 8 of April 8, 1997 , Decree \\
July 8, 1997, and Decree 31 of \\
October 7, 1997) \\
3. Taxes on international trade 2 \\
3.1 Taxes on imports \\
3.1.1 Import duties (Direitos de \\
Importação)
\end{tabular}

(Decree 42 of October 15, 1996)

3.1.2 Customs fees (Taxa de Serviços Aduaneiros)

(Decree 42 of October 15, 1996)

\subsection{Taxes on exports}

3.2.1 Export duties (Direitos de Exportação)

Tax on export of raw cashew nuts (Law $13 / 99$ of November 1,1999 )
Nature of tax

Exemptions and deductions

and Mt l,100 per liter of regular and premium gasoline,

respectively, which go to the Road and Bridge

Maintenance Fund

Eighty percent of receipts from the tax on diesel go to the

Road and Bridge Maintenance Fund.

Levied on all imports according to the import tariff unless exempt by special provision. The tariff follows the CCCN classification. Ad valorem duties are based on c.i.f. value of imports, determined according to the Brussels Definition of Value. About half the tariff items are subject to specific rates.

Exempted are (a) imports for diplomatic services, travelers' baggage, works of art, imports with no commercial value, and other traditionally exempted imports; (b) imports associated with external grants and externally financed projects; (c) capital goods imported under the investment incentives law; and (d) oil products.

A single-rate fiscal duty levied on the c.i.f. value of imports.

Imports belonging to category (a) above are exempt. Other exemptions are being granted for emergency program and defense imports, subject to existing international agreements.

A reduced rate of 2.5 percent is applied to imports of raw materials and finished goods.

None.
Rates

$\begin{array}{lr}\text { Diesel } & 1,825.00 \\ \text { Fuel oil } & \mathbf{3 2 8 . 3 0}\end{array}$

Rates are subject to adjustment by the Minister of Planning and Finance as necessary.

Bulk sales restricted to distributors.

Most consumer goods are taxed at a $5-25$ pencent rate.

Some textiles and luxury goods are taxed at 35 percent.

Raw materials and intermediate goods, I-30 percent.

Machinery in general, 5 percent. Other capital goods, 5-35 percent.

Nonprocessed food products, 35 percent.

A 10 percent reduction is applied to some rates as preferential treatment, and a 5 percent applies to imports of raw materiais and finished or semi-finished materiais and finished or semi-finished
goods used in or added to manufactured goods, provided that the original rate is higher.

1 percent.

1 percent. 


\section{Other}

4.1 Poll tax (Imposto de Reconstruçào Nacional)

(Decree 4 of January 30, 1987 -

National Reconstruction Tax Code and Ministerial Order 21.A of January 31, 1992; Ministerial Order 2/94,

Ministerial Order 113 of December 20, 1995, and Ministerial Order 142 of November 13, 1996)

Ministerial Order 204 of November 18, 1998 (scts rates for 1999)

Ministerial Order 111 of October 27, 1999 (sets rates for 2000)

4.2 Stamp tax (Imposto do Selo) (Legislative Act 763 of August 11, 1941 , as amended. Decree 19 of May 9 1995, and Decree 32 of October 14.

1997)

A head tax levied annually on all citizens and aliens who earn income taxable subject to the Labor Income Tax Section A, the Business Profits Tax, or the Complementary Tax, and on all male residents between 18 and 60 years of age. The proceeds of the tax are allocated as follows: 5 percent to officials in charge of the taxpayer census and tax assessment, 70 percent to provincial budgets, and 25 percent to district budgets.
Exempted from the tax are (a) full-time students in the national education system, until 25 years of age if attending college; (b) persons incapacitated for work becruse of weakness, illness, or physical disability; (c) citizens in the military service (d) pensioners receiving no income other than their pensions; and (e) diplomats.

The code provides for temporary exemption of taxpayers who are unable to meet the tax obligation because of natural disasters; exemption is granted by the Minister of Planning and Finance upon proposa of provincial governments.

\section{Reqular/Late Payment}

Maputo (city and province)

cities of Beira, Nampula,

and Tete

Mt $15,000-22,500$

Cities of Xaj-Xai,

Inhambane,

Chimoio,

and Pemba

ity of Quelimane Mt 8,000-12,000

Lichinga

Provinces and

Districts

Mt $6,000-9,000$

Mt $10,000-15,000$

In all provinces and their districts:

Normal payment - Mt 10,000

Late payment - Mt 15,000

In all provinces and their districts:

Normal payment - Mt 10,000

Late payment - Mt 15,000

Requirement that revenue stamps be affixed to official papers, accounting, and register books, and documents

such as those used for import and export purposes;

receipts; contracts; bills of exchange; bonds; and a wide range of business licenses and permits and for sale of some products, such as lottery and sports tickets. Use of stamped paper is also required for a variety of legal documents. In many cases, stamp taxes are equivalent to a sales tax on goods and services, particularly those subject to ad valorem rates.
A variety of documents and certificates, mostly those issued by the government, are exempt.

Also exempted are the notarization of signatures, by public notaries or other duly authorized entities, as well as petitions, drafts, pleadings, rejections and respective replies, declarations, claims or grievances filed with all public offices or courts of law.
Various rates apply to different types of documents. The following are examples of ad valorem rates:

(In percent)

Lending operations

Equity shares

0.1

Import and export transactions

Insurance policies:

Life insurance

Maritime shipping

Other

Most rates are specific. Examples: 
Civil partnerships, on their stock

Business corporations, on their capital, whether or not immediately paid in

Issuance of member card or admission ticket to casinos or other gambling establishments, on the card or ticket value

Prizes in all other gambling activities, upon payment, on their value

Decree 33 of October 17, 2000 establishes fiscal measures applicable to securities market participants

4.3 Tourism tax (Imposto de Turismo) (Legislative Act 2732 of December 3 , 1966, as amended by Legislative Act 2748 of March 25, 1967 Decree-Law 3 of January 7, 1985, and Circular 18/4/1//DGCI of May 8, 1979 ; Decree 33 of August 9, 1995)

Levied on the value of hotel and tourism services: accommodations, food, and beverages at hotels, boardinghouses, inns, restaurants, motels, camping grounds (including those for hunting), nightclubs, and ballrooms.

The following are classified as having tourist interest: beerhouses, teahouses, cafés, bars, snack bars, eateries, taverns, and similar establishments.

Law 3 of May 25, 2000 - revokes the Tourism Tax established by Legislative Act 2732 of December 3, 1966

4.4 Motor vehicle tax (Imposto de
The acts provided for in Articles 2, 63, 108, 122 , 140 , and 141 of the general schedule of the stamp tax, attached to the respective regulated, when

executed on the presumption of initial listing in the Mozambique Stock Exchange, are exempt from the stamp tax.

None.

3 percent.

2 percent on services rendered by travel agents and tour operators. 


\begin{tabular}{|c|c|c|c|}
\hline Tax & Nature of tax & Exemptions and deductions & Rates \\
\hline $\begin{array}{l}\text { Compensação) } \\
\text { (Decree } 24 \text { of August } 8,1989 \text { ) }\end{array}$ & on gasoline. & $\begin{array}{l}\text { (b) foreign states, when there is reciprocity of } \\
\text { treatment; (c) personnel of diplomatic and consular } \\
\text { missions; (d) farm tractors; and (e) vehicles for } \\
\text { driving instruction, for sale, seized, or unused for } \\
\text { more than three months. }\end{array}$ & Heavy vehicles \\
\hline $\begin{array}{l}\text { Ministerial Onder } 5 \text { of February 3, } 1999 \\
\text { (sets the motor vehicle tax for 1999) }\end{array}$ & & & $\begin{array}{l}\text { The rate varies according to the type of } \\
\text { vehicle. }\end{array}$ \\
\hline
\end{tabular}

Source: Ministry of Planning and Finance.

$\underline{1}$ / Other taxes remain in effect, but their importance decreases sharply owing to the nationalization of Jand and urban property. They are the tax on rental income (contribuição predial), levied annually on the actual or presumed rental value of urban property; the gift and inheritance tax (Imposto sobre as Sucessóes $e$ Doaçốes), formerly chargeable to the beneficiary; and the real property transfer tax (Sisa). The first of these taxes is provisionally regulated by Title IV of the Code approved by Legislative Act 2774 of September 16, 1967; the other two come essentially under Decree 31408 of July $19,1914$.

2/ Some minor duties have been maintained in the customs legislation, despite the tariff reform (Decree 14 of June 19, 1991). In addition to the stamp tax, the following also apply: (a) to imports, revenue stamp tax on the consumption tax and broadcasting fee; and (b) to both imports and exports, the warehousing fee and the maritime trade tax, the latter established by the General Maritime Taxes Regulations (Legislative Act 627 of February 8, 1939), based on weight. Although not included in the current customs legislation, two very minor taxes established by the aforementioned regulations are also collected by customs: the lighthouse tax (imposto de farolagem) and the tonnage tax (imposto de tonelagem) 